\title{
Historical Eruptions and Hazards at Bogoslof Volcano, Alaska
}

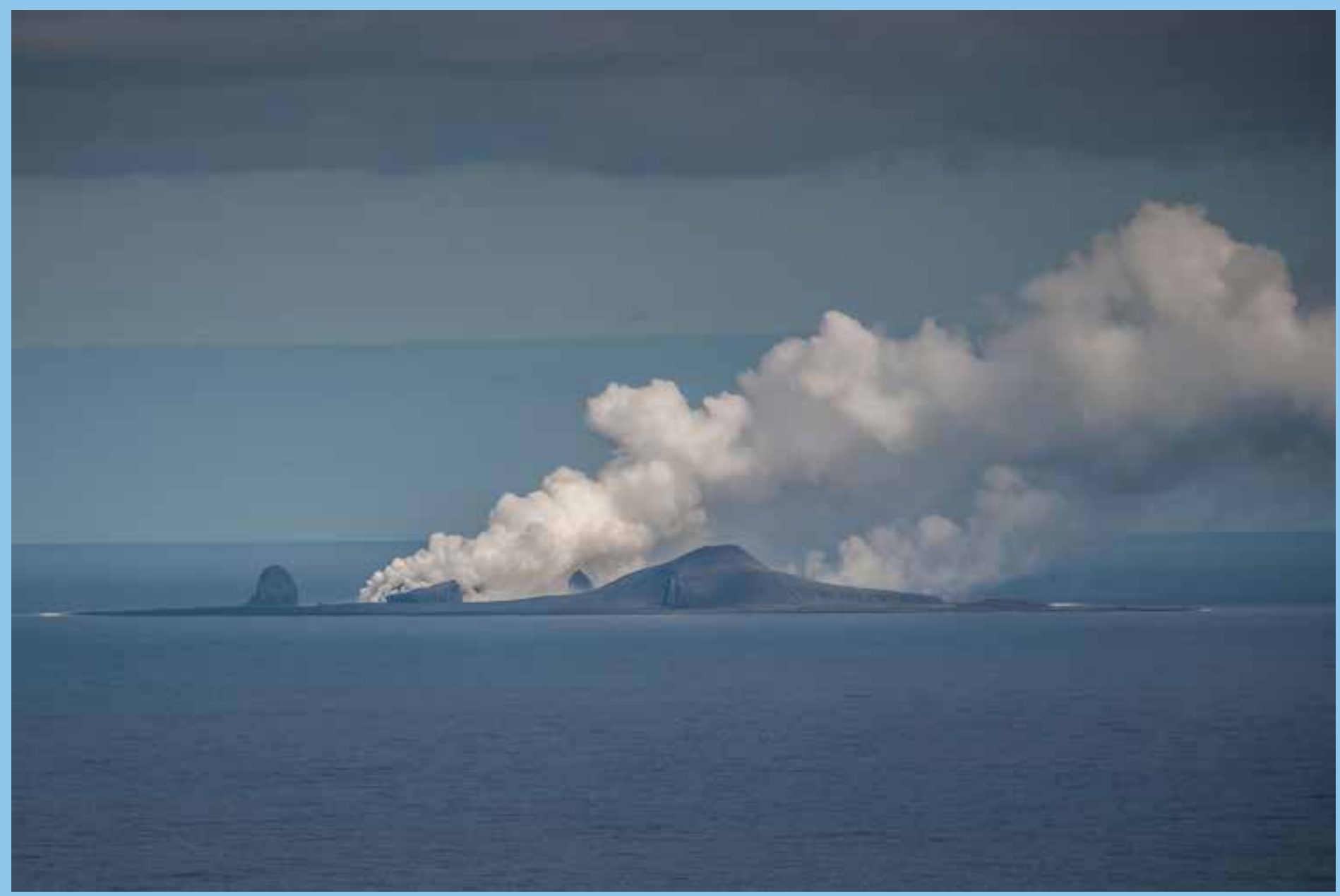

Scientific Investigations Report 2018-5085 
Cover. Bogoslof Island and vigorous steam plume generated by the interaction of a recently emplaced lava dome with seawater. Photograph by Dave Withrow, National Oceanic and Atmospheric Administration [NOAA]/Fisheries, taken at about 13:00 AKDT on August 26, 2017, aboard a NOAA aircraft roughly 13 nautical miles southwest of Bogoslof Island. 


\section{Historical Eruptions and Hazards at Bogoslof Volcano, Alaska}

By Christopher F. Waythomas and Cheryl E. Cameron

Scientific Investigations Report 2018-5085 


\title{
U.S. Department of the Interior \\ RYAN K. ZINKE, Secretary
}

\author{
U.S. Geological Survey \\ James F. Reilly II, Director
}

U.S. Geological Survey, Reston, Virginia: 2018

For more information on the USGS - the Federal source for science about the Earth, its natural and living resources, natural hazards, and the environment-visit https://www.usgs.gov or call 1-888-ASK-USGS.

For an overview of USGS information products, including maps, imagery, and publications,

visit https://www.store.usgs.gov/.

Any use of trade, firm, or product names is for descriptive purposes only and does not imply endorsement by the U.S. Government.

Although this information product, for the most part, is in the public domain, it also may contain copyrighted materials as noted in the text. Permission to reproduce copyrighted items must be secured from the copyright owner.

Suggested citation:

Waythomas, C.F., and Cameron, C.E., 2018, Historical eruptions and hazards at Bogoslof volcano, Alaska:

U.S. Geological Survey Scientific Investigations Report 2018-5085, 42 p., https://doi.org/10.3133/sir20185085.

ISSN 2328-0328 (online) 


\section{Preface}

Despite its remote location, a surprising number of people have visited Bogoslof Island since it was first depicted on a Russian map in 1772. Visitors to the area often described eruptive activity using colorful language or offered speculative remarks that were vindicated by subsequent eruptions as the following quotes demonstrate. Intermittently I could see a solid rock core in the pudding, round, and towering above its center. "It's the d___dest thing. The d___dest thing!" I kept on saying to myself. And over me crept the delicious thrill of the volcano-chaser: fear without responsibility, eagerness without lust, awe without wonder at old Nature so busy at her simple, terrible work.-Robert Dunn, 1908, as he approached a recently erupted lava dome at Bogoslof, 1906.

"Presumably other domical masses of viscous lava will rise at Bogoslof and these will be partly or wholly demolished by explosions and by wave attack, for this, as the foregoing record shows, has been the oft-repeated story of Bogoslof since records were first kept in 1796."-H.A. Powers, 1958. 


\section{Contents}

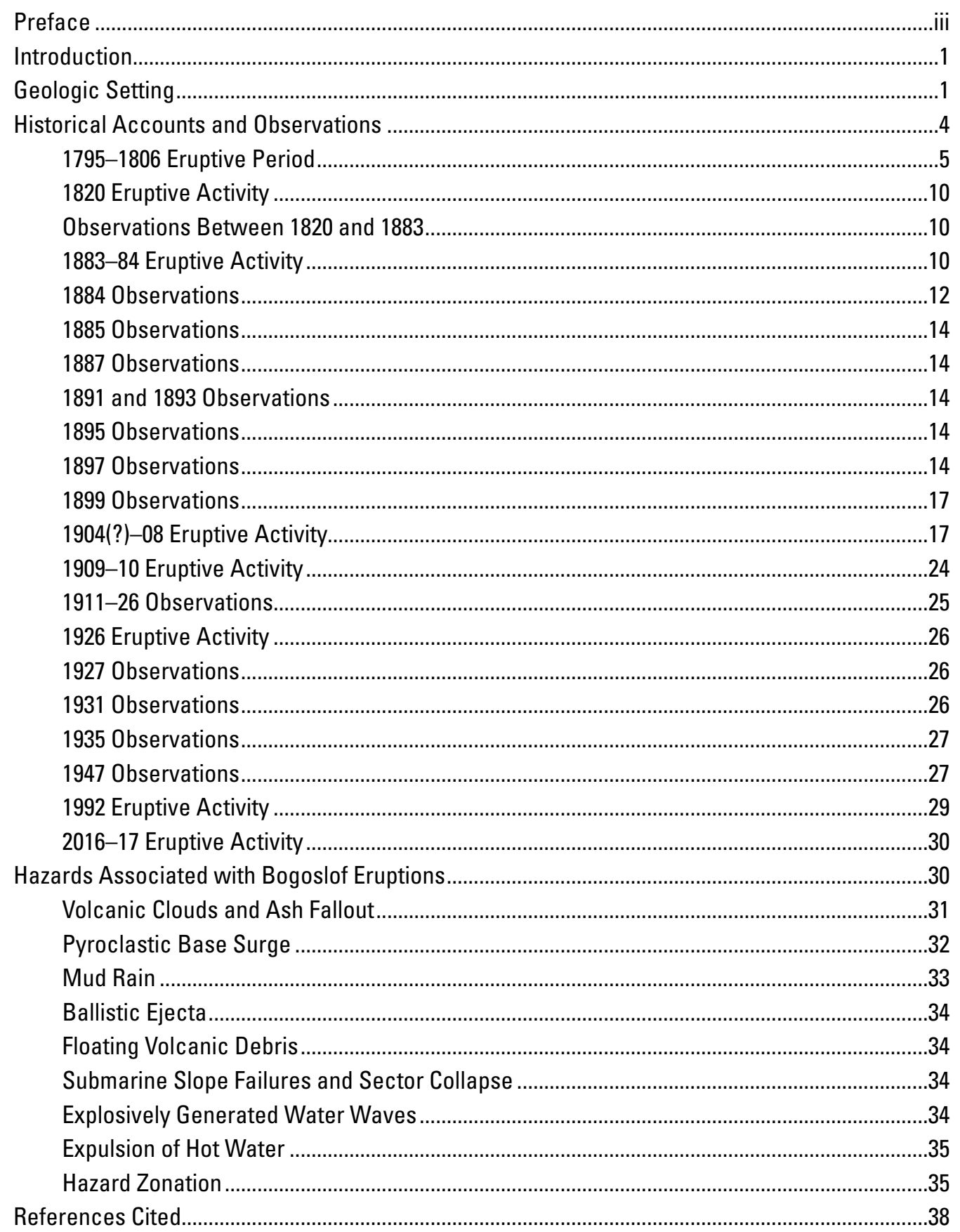




\section{Figures}

1. Location maps of Bogoslof volcano with respect to local bathymetric features and regional volcanoes and volcanic centers

\section{2}

2. Location map of Bogoslof Island with respect to other nearby active Aleutian arc volcanoes in the region.

\section{3}

3. Aerial photograph of Bogoslof and Fire Islands taken May 10, 1994, showing four subaerial

outcrops of lava emplaced during historical eruptions ..................................................

4. Bathymetric map of the Bogoslof volcano edifice showing location of Bogoslof Island and the locations of historically active vents 4

5. Portion of the 1772 map of the Krenitsyn and Levashev voyage showing the first known map depiction of an island in the vicinity of the present day Bogoslof Island...........................5

6. Map of Bogoslof Island and Ship Rock, after Krusenstern .......................................................

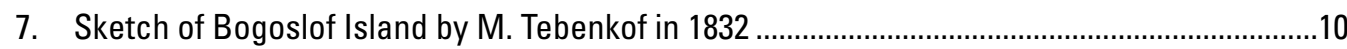

8. Hand drawn sketch of Bogoslof Island by G. Davidson based on descriptions provided during interviews with Captains Anderson and Hague who observed this feature in September-0ctober 1883 .. (1) (1)

\section{0}

9. Outlines of sand-sized ash particles from the October 20, 1883, ash fall on Unalaska ............12

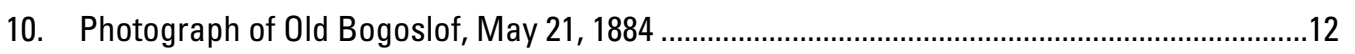

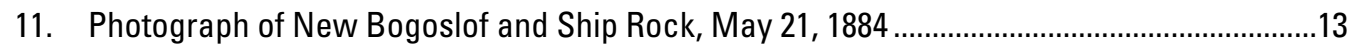

12. An 1884 map of Bogoslof Island showing Old Bogoslof, Ship Rock, and New Bogoslof, which was a result of eruptive activity between 1882 and 1884 ..

13. Map of Bogoslof Island made by G.M. Stoney based on observations made in late May 1884

14. Photograph of steam emissions from New Bogoslof Island, August 11, 1891 ........................15

15. Sketch map of Old and New Bogoslof Islands in 1891 by C. Hart Merriam, showing new spit extending northwest of Old Bogoslof and absence of spit connecting Old and New

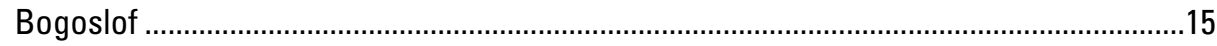

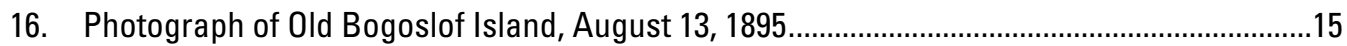

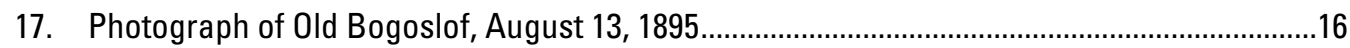

18. Sketch map of Old and New Bogoslof Islands, made in 1895 by W.H. Dall ...........................16

19. Sketch of New Bogoslof and Old Bogoslof made from photograph taken by L. Stejneger,

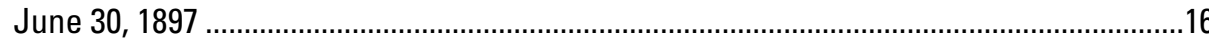

20. Photograph of Old Bogoslof and New Bogoslof, July 8, 1899............................................17

21. Photograph of 1906 lava dome from New Bogoslof when visited by crewmen of the U.S. Revenue steamer Perry, July 29, 1906.

22. Sketch of lava dome erupted in 1906 as observed by sailors on board the Revenue cutter

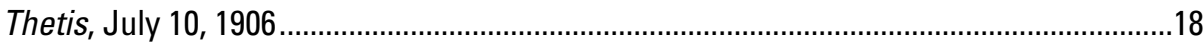

23. Sketch map of the Bogoslof Island area July 29, 1906, by Robert Dunn .................................18

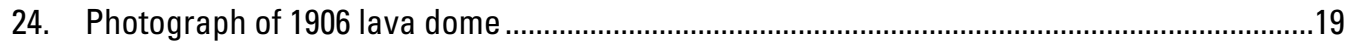

25. Photograph of upper part of 1906 lava dome...................................................................

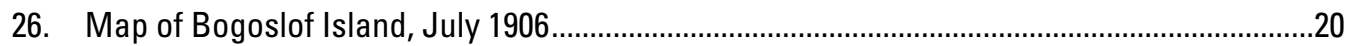

27. Photograph of Old Bogoslof on left, Metcalf Cone in middle, and New Bogoslof on right

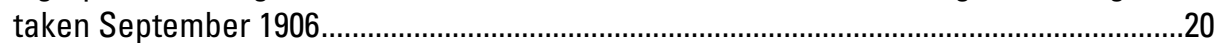

28. Photograph of the Bogoslof area taken July 4, 1907 .........................................................21

29. Photograph of the Bogoslof area taken August 7, 1907, showing four lava accumulations and the names used in various publications describing them.......................................21

30. A 1907 map of the Bogoslof area showing the four main volcanic vents at the time .............22 
31. Photograph of partly destroyed Metcalf Cone and McCulloch Peak, August 7, 1907 ...........22

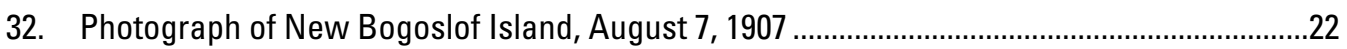

33. Photograph of New Bogoslof, Metcalf Cone, and Old Bogoslof, October 15, 1907 ...............23

34. Photograph of Bogoslof Island taken July 1908 showing Old and New Bogoslof and the approximate locations of Metcalf Cone and McCulloch Peak, both of which were removed by explosive eruptive activity September 1907-July 1908.

35. July 1908 map of Bogoslof Island, made by Lieutenant Bernard H. Camden of the Revenue cutter Rush.

36. Sketch map of Bogoslof Island, September 10, 1910, by Lieutenant A.H. Scally, U.S. Rev-

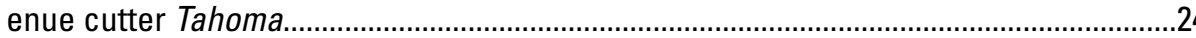

37. Photograph of Bogoslof volcano erupting September 19, 1910

38. Photograph of steaming lava dome on Bogoslof Island, June 28, 1928, view is toward the

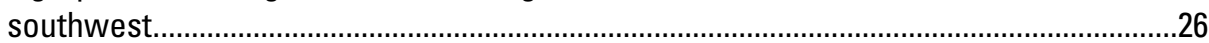

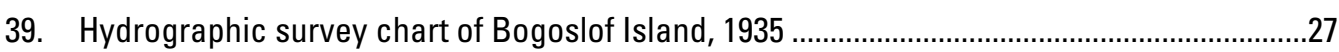

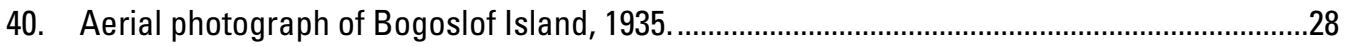

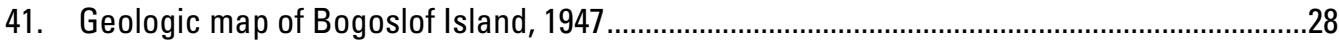

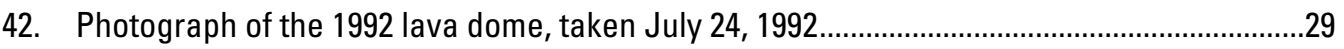

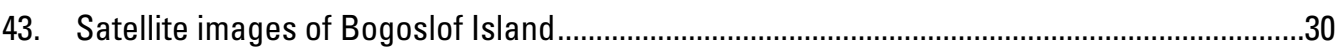

44. Photograph of volcanic eruption cloud at Bogoslof volcano, taken February 19, 2017 .........31

45. Satellite image of steam-rich eruption column and developing base surge at Bogoslof

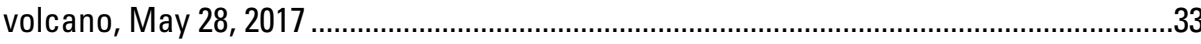

46. Landsat 8 Operational Land Imager natural-color image of Bogoslof, June 5, 2017.............35

47. Photograph of Bogoslof Island, January 10, 2017........................................................36

48. Preliminary hazard map for Bogoslof volcano based on historical eruptive activity .............37

\section{Tables}

1. Summary of observations of eruptive activity and other phenomena at Bogoslof Island,

1795-2017 


\section{Conversion Factors}

U.S. customary units to International System of Units

\begin{tabular}{|c|c|c|}
\hline Multiply & By & To obtain \\
\hline \multicolumn{3}{|c|}{ Length } \\
\hline foot $(\mathrm{ft})$ & 0.3048 & meter $(\mathrm{m})$ \\
\hline mile (mi) & 1.609 & kilometer (km) \\
\hline mile, nautical (nmi) & 1.852 & kilometer (km) \\
\hline yard (yd) & 0.9144 & meter $(\mathrm{m})$ \\
\hline \multicolumn{3}{|c|}{ Area } \\
\hline acre & 4,047 & square meter $\left(\mathrm{m}^{2}\right)$ \\
\hline acre & 0.004047 & square kilometer $\left(\mathrm{km}^{2}\right)$ \\
\hline square foot $\left(\mathrm{ft}^{2}\right)$ & 929.0 & square centimeter $\left(\mathrm{cm}^{2}\right)$ \\
\hline square foot $\left(\mathrm{ft}^{2}\right)$ & 0.09290 & square meter $\left(\mathrm{m}^{2}\right)$ \\
\hline square mile $\left(\mathrm{mi}^{2}\right)$ & 2.590 & square kilometer $\left(\mathrm{km}^{2}\right)$ \\
\hline \multicolumn{3}{|c|}{ Volume } \\
\hline gallon (gal) & 0.003785 & cubic meter $\left(\mathrm{m}^{3}\right)$ \\
\hline million gallons (Mgal) & 3,785 & cubic meter $\left(\mathrm{m}^{3}\right)$ \\
\hline cubic foot $\left(\mathrm{ft}^{3}\right)$ & 0.02832 & cubic meter $\left(\mathrm{m}^{3}\right)$ \\
\hline cubic yard $\left(\mathrm{yd}^{3}\right)$ & 0.7646 & cubic meter $\left(\mathrm{m}^{3}\right)$ \\
\hline cubic mile $\left(\mathrm{mi}^{3}\right)$ & 4.168 & cubic kilometer $\left(\mathrm{km}^{3}\right)$ \\
\hline acre-foot (acre-ft) & 1,233 & cubic meter $\left(\mathrm{m}^{3}\right)$ \\
\hline \multicolumn{3}{|c|}{ Flow rate } \\
\hline foot per second $(\mathrm{ft} / \mathrm{s})$ & 0.3048 & meter per second $(\mathrm{m} / \mathrm{s})$ \\
\hline cubic foot per second $\left(\mathrm{ft}^{3} / \mathrm{s}\right)$ & 0.02832 & cubic meter per second $\left(\mathrm{m}^{3} / \mathrm{s}\right)$ \\
\hline
\end{tabular}

Temperature in degrees Celsius $\left({ }^{\circ} \mathrm{C}\right)$ may be converted to degrees Fahrenheit ( ${ }^{\circ} \mathrm{F}$ ) as follows: ${ }^{\circ} \mathrm{F}=\left(1.8 \times{ }^{\circ} \mathrm{C}\right)+32$.

Temperature in degrees Fahrenheit $\left({ }^{\circ} \mathrm{F}\right)$ may be converted to degrees Celsius $\left({ }^{\circ} \mathrm{C}\right)$ as follows: ${ }^{\circ} \mathrm{C}=\left({ }^{\circ} \mathrm{F}-32\right) / 1.8$.

\section{Abbreviations}

$\begin{array}{ll}\text { AVO } & \text { Alaska Volcano Observatory } \\ \text { USGS } & \text { U.S. Geological Survey }\end{array}$





\title{
Historical Eruptions and Hazards at Bogoslof Volcano, Alaska
}

\author{
By Christopher F. Waythomas ${ }^{1}$ and Cheryl E. Cameron ${ }^{2,3}$
}

\section{Introduction}

Bogoslof volcano is a submarine volcano in the southern Bering Sea $\left(53.9272^{\circ} \mathrm{N}, 168.0344^{\circ} \mathrm{W}\right)$, located 100 kilometers $(\mathrm{km})$ west of Dutch Harbor/Unalaska, and $40 \mathrm{~km}$ north of Umnak Island. The volcano has a relatively long history of scientific investigation and several of its historical eruptions have been documented during brief visits to the area since the late $1700 \mathrm{~s}$. The purpose of this report is to provide a modern volcanological perspective on past eruptions of Bogoslof and to readdress some of the eruptive phenomena described in historical documents and reports. We also present for the first time a brief analysis of the hazards posed by Bogoslof eruptions. While this report was being prepared, Bogoslof volcano was in an ongoing state of eruptive activity that began in mid-December 2016. Detectable eruptive activity ended in late August 2017 and the volcano has remained quiet since then. Because we have not yet visited Bogoslof Island and have only a few distal tephra samples from two eruptive events, we will not discuss in detail the 2016-17 eruptive sequence, but will provide some information for comparative purposes. When more detailed data has been collected, a more extensive review of the 2016-17 Bogoslof eruption should be the subject of future reports.

\section{Geologic Setting}

Bogoslof volcano is a submarine volcano roughly 130 cubic kilometers $\left(\mathrm{km}^{3}\right)$ in volume located about $50 \mathrm{~km}$ north of the main Aleutian arc volcanic front (figs. 1 and 2). The volcano is considered a back-arc feature because of its location north of, or behind, the Aleutian arc. Bogoslof is one of several volcanoes situated north of the volcanic front, the others being Amak volcano, which is located north of Cold Bay (Marsh and Leitz, 1979), and several volcanoes and volcanic edifices in the Katmai region (Hildreth and others, 2007). Two modern islands, Bogoslof Island and Fire Island,

\footnotetext{
${ }^{1}$ U.S. Geological Survey.

${ }^{2}$ Alaska Division of Geological and Geophysical Surveys.

${ }^{3}$ Alaska Volcano Observatory.
}

make up the subaerial part of the volcano (fig. 3). The submarine edifice of Bogoslof volcano has $\sim 1,800$ meters $(\mathrm{m})$ of relief (fig. 2), but the highest points on Bogoslof Island are currently $<100 \mathrm{~m}$ above sea level. Subaerial accumulations of lava are variously shaped. For example, the 1926-27 lavas are dome shaped in appearance (fig. 3), whereas Castle Rock and the 1992 lavas have an angular, spine-like shape, similar to lava spines described elsewhere (Sherrod and others, 2008). The subaerial lava flows have been referred to as lava domes in some previous studies (Byers, 1959, 1961), but the lava morphology probably has as much to do with the postemplacement weathering and marine erosion of the rock as it does with lava composition, rheology, and cooling history. For the purposes of this report we consider all mounds of volcanic rock that have accumulated around a volcanic vent as lava domes following the terminology described in Calder and others (2015). We use the term lava dome in a morphologic sense only and make no implications about whether Bogoslof is a dome-building volcano and thus susceptible to the effects of cyptodome intrusion and flank instability commonly associated with volcanoes that produce lava domes.

Bogoslof volcano is situated just south of the Bering Shelf, in the extreme southeast corner of the Aleutian Basin (fig. 1; Scholl and others, 1975). The volcano is flanked by structurally controlled submarine canyons on the north side of the Aleutian Ridge and is about $50 \mathrm{~km}$ east of the Umnak Plateau, a major bathymetric rise in the Aleutian Basin (Scholl and others, 1968, 1970). Umnak Plateau is a triangular shaped surface between 1,800 to $1,900 \mathrm{~m}$ below sea level at the intersection of the southwest trending Aleutian Ridge and the northwest trending Bering Shelf continental slope (Scholl and others, 1968; Ben-Avraham and Cooper, 1981). The relation between the location of these structures and Bogoslof volcano is unclear. The center points of the lava domes produced during historical eruptions form a linear alignment that is oriented roughly $\mathrm{N} 5^{\circ} \mathrm{W}\left(355^{\circ}\right.$;fig. 4$)$ and approximately parallel to the direction of plate convergence in this part of the Aleutian arc (Engebretson and others, 1985; Tibaldi and Bonali, 2017).

The Aleutian arc extends westward from Cook Inlet in the east (approximately $61^{\circ} \mathrm{N}, 152^{\circ} \mathrm{W}$ ) to Attu Island $\left(52^{\circ} 56.9970^{\prime} \mathrm{N}, 172^{\circ} 35.3310^{\prime} \mathrm{E}\right)$. Buldir Island, about $200 \mathrm{~km}$ east of Attu (fig. 1), is the westernmost island with known subaerial Holocene volcanism (Wood and Kienle, 


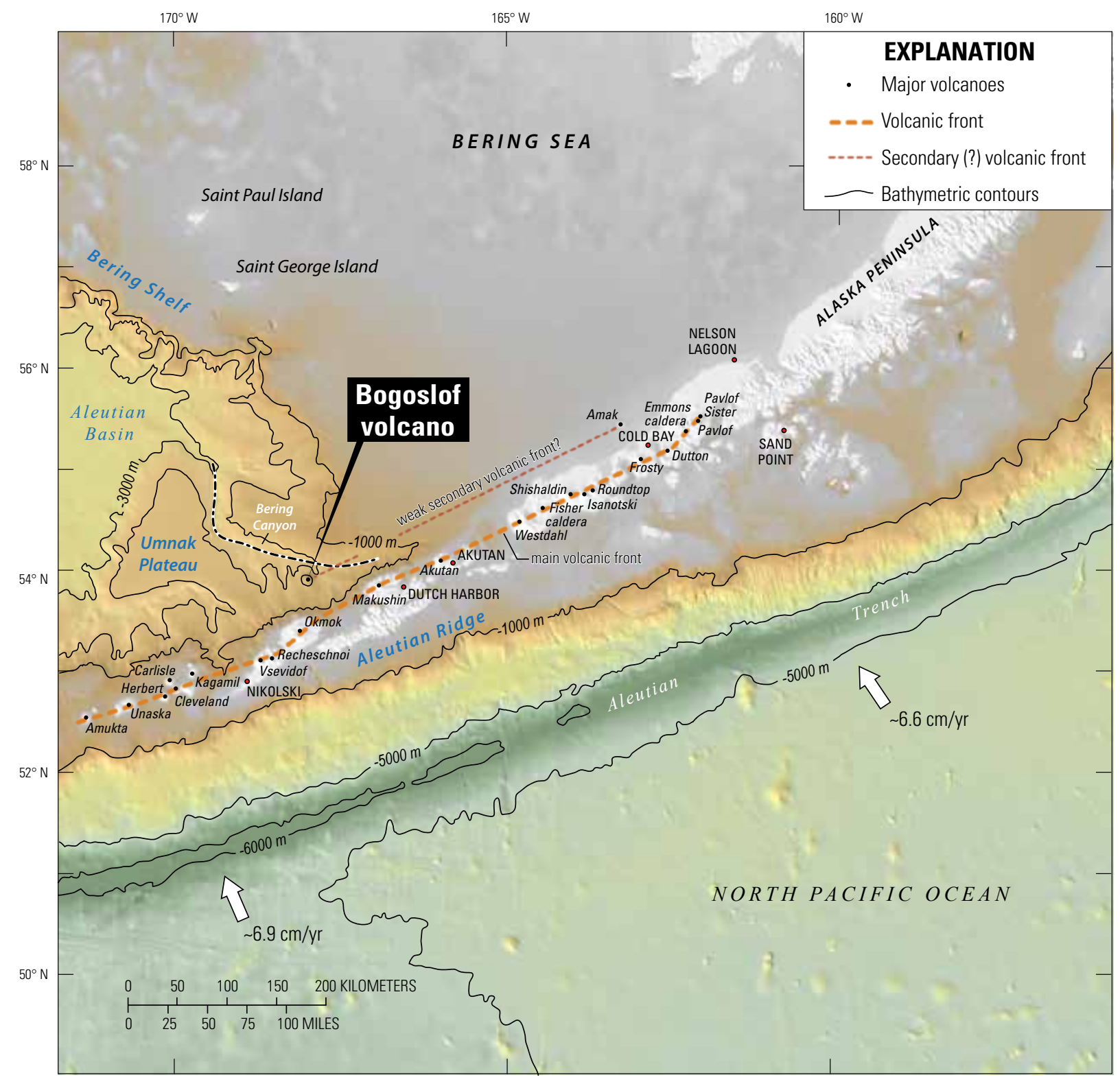

Bathymetric data from GEBCO 2104 global 30 arc-second interval grid.

Shaded relief imagery from ETOPO1 1 arc-minute global relief model

Figure 1. Location maps of Bogoslof volcano with respect to local bathymetric features and regional volcanoes and volcanic centers. $\mathrm{M}$, meters; $\mathrm{cm} / \mathrm{yr}$, centimeters per year.

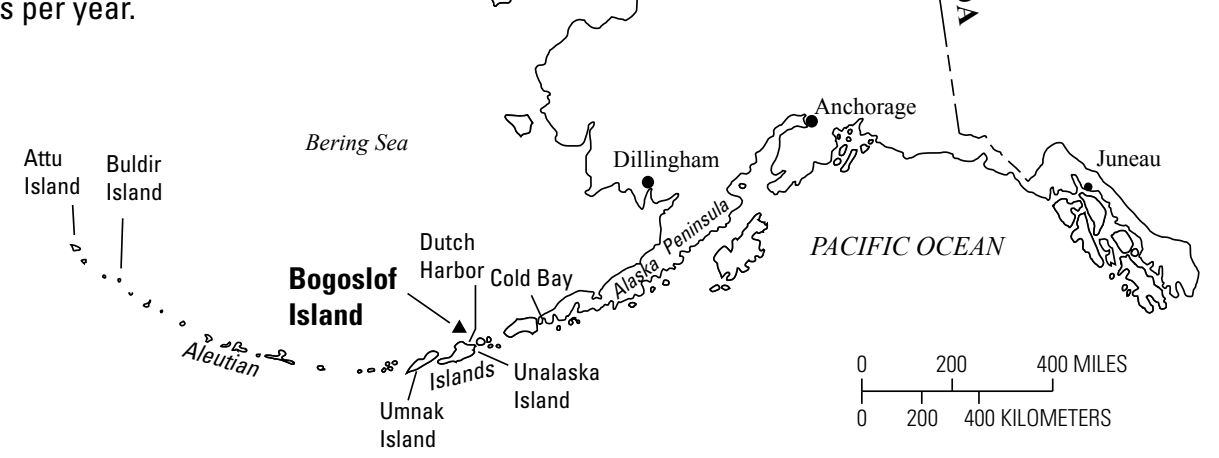




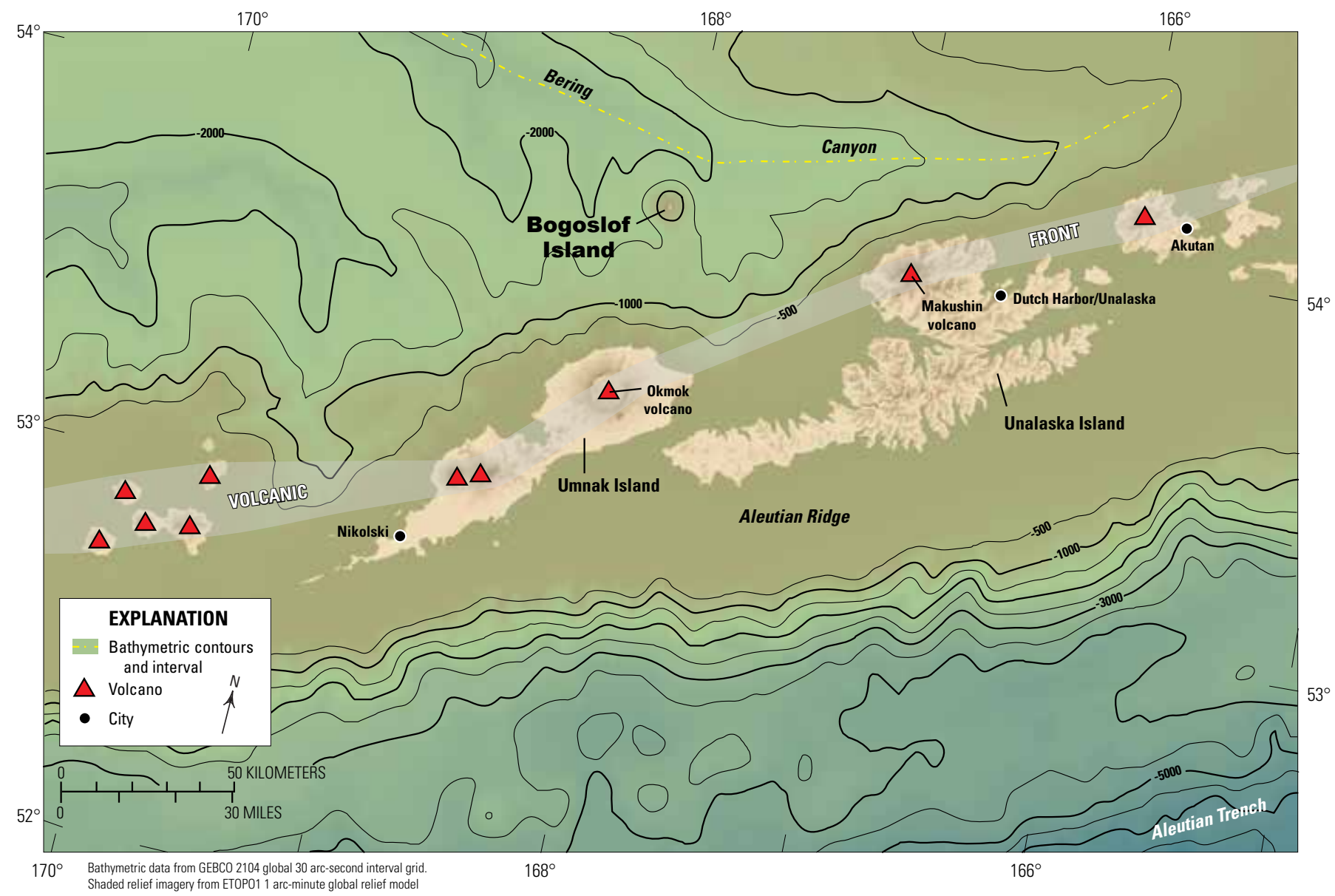

Figure 2. Location map of Bogoslof Island with respect to other nearby active Aleutian arc volcanoes (red triangles) in the region. Bogoslof volcano is an example of a back-arc volcano because it is situated north of, or behind the main volcanic front.

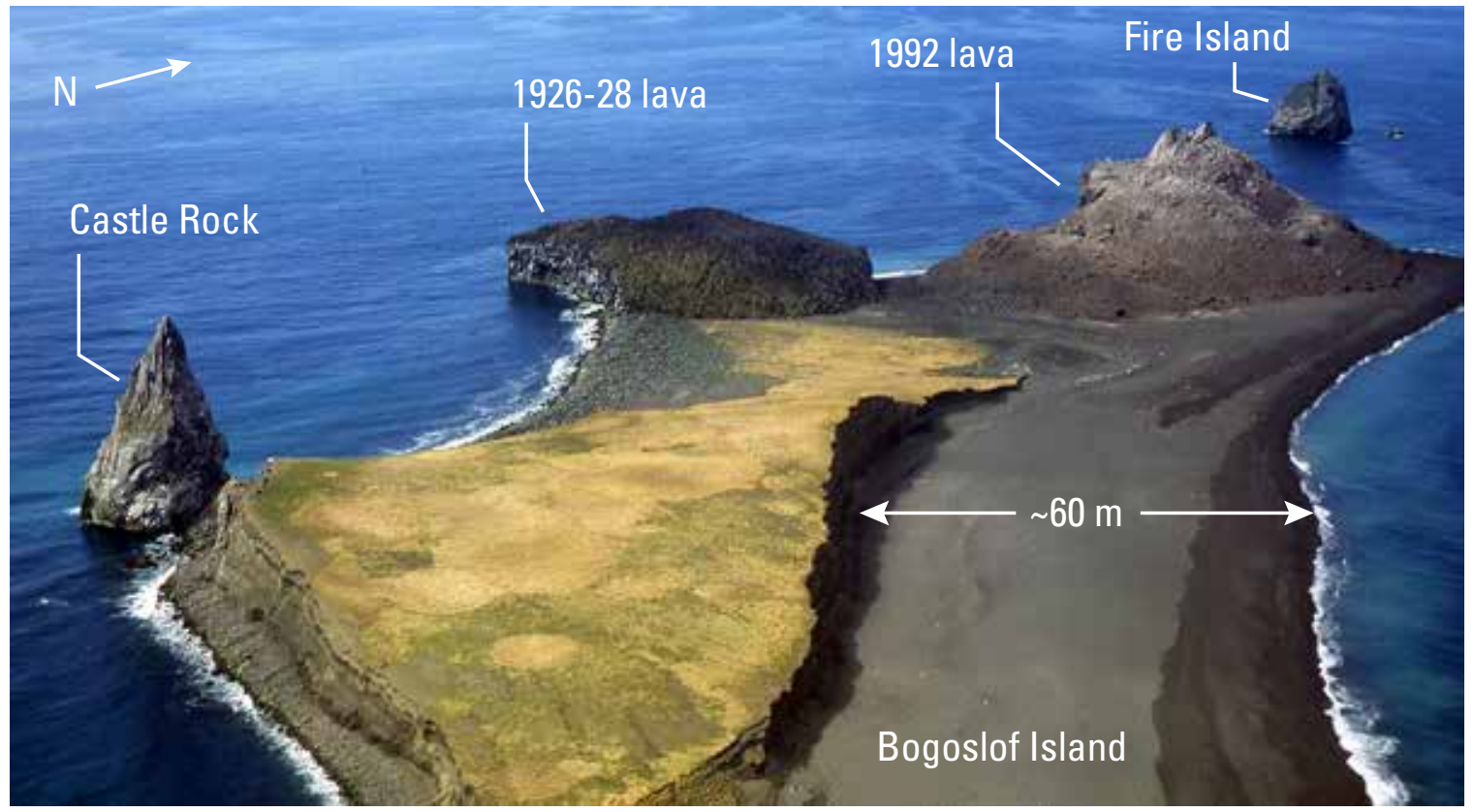

Figure 3. Aerial photograph of Bogoslof and Fire Islands taken May 10, 1994, showing four subaerial outcrops of lava emplaced during historical eruptions. Photograph by Chris Nye, Alaska Division of Geological and Geophysical Surveys and Alaska Volcano Observatory. M, meters. 


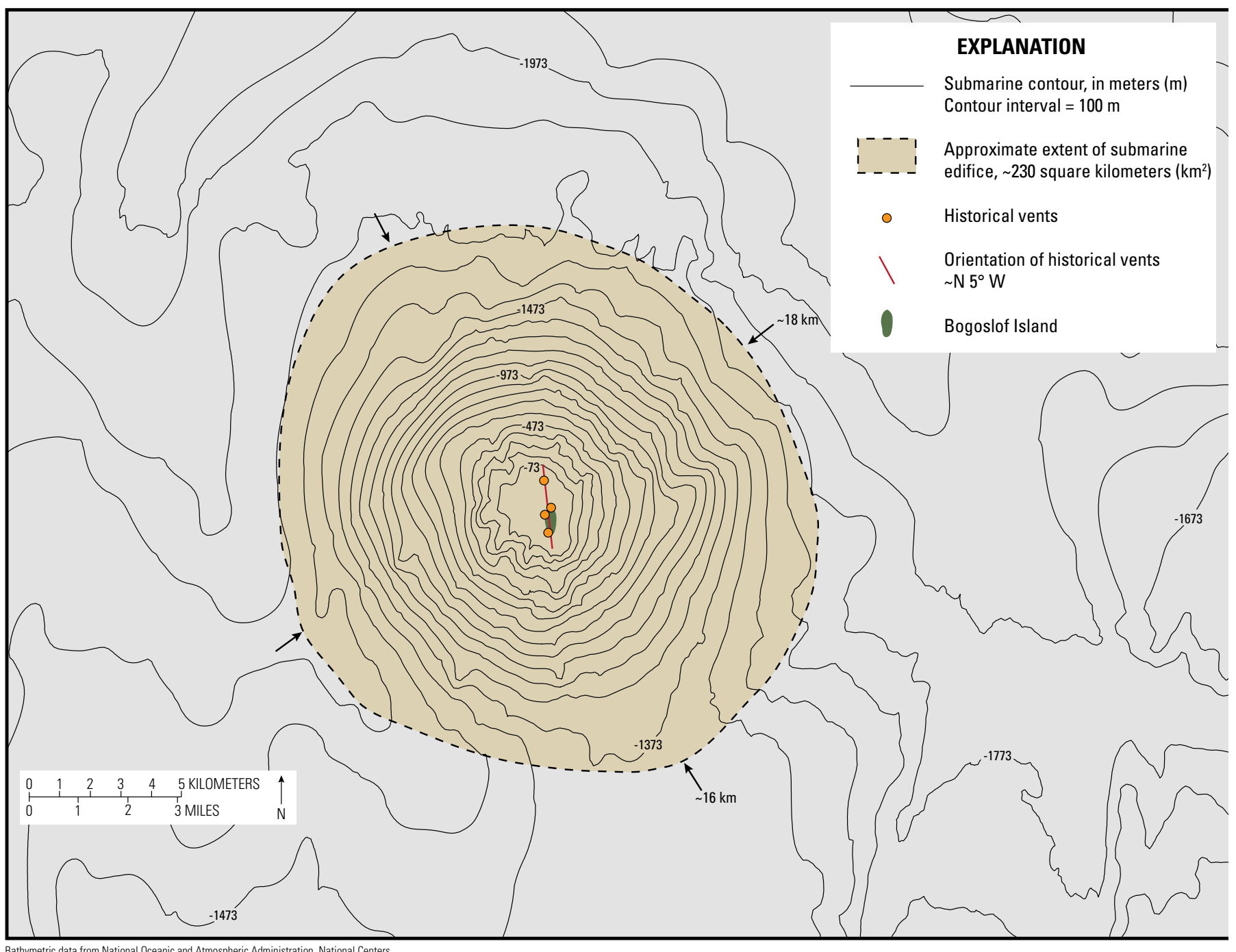

Figure 4. Bathymetric map of the Bogoslof volcano edifice showing location of Bogoslof Island and the locations of historically active vents, which are aligned along a N $5^{\circ} \mathrm{W}\left(355^{\circ}\right)$ orientation. The vents from north to south are Fire Island, 1992 lava, 1926-28 lava, and Castle Rock. See figure 2 for oblique view of these features.

1990). In the eastern part of the arc, the plate convergence vector is approximately 90 degrees to the trench axis and convergence rates are about 7.5 centimeters per year $(\mathrm{cm} / \mathrm{yr})$. To the west, the convergence vector becomes more oblique and convergence rates decline to about $2.5 \mathrm{~cm} / \mathrm{yr}$ and eventually all of the motion in the western part of the arc becomes strike-slip (Engebretson and others, 1985). In the eastern part of the arc, volcanoes have developed on continental crust and are situated $300-500 \mathrm{~km}$ north of the trench (Jacob and others, 1977).

Volcanoes in the central to western part of the arc (including Bogoslof) grew from largely submarine environments within $200 \mathrm{~km}$ of the trench. Bogoslof volcano is located in the central part of the Aleutian arc and is about $215 \mathrm{~km}$ northwest of the trench (figs. 1 and 2). In general, the central part of the arc is the area of greatest magmatic output as indicated by volcano volume and frequency of historical eruptions (Fournelle and others, 1994). The two volcanoes closest to Bogoslof, Okmok and Akutan, are very active centers and have had numerous historical eruptions (www.avo.alaska.edu).

\section{Historical Accounts and Observations}

The first map depiction of an island in the vicinity of modern day Bogoslof Island is the 1772 map of the Krenitsyn and Levashev voyage (Shavanov, 1772) from Kamchatka to the Fox Islands between 1768 and 1769 (fig. 5). Pyotr Kuzmich Krenitsyn and Mikhail Levashev were officers and explorers in the Russian Navy who were dispatched to explore the northern Pacific Ocean and Bering Strait region by the Russian Empress Catherine II. The map of their voyage shows a small angular shaped island surrounded by cross marks in roughly the present location of Bogoslof Island (fig. 5). The cross marks are not described on the map explanation, but are 
a common symbol long-used on maritime maps that represent rocks, reefs, or shoalwater that are hazards to navigation (Larkin, 1998). On October 29, 1778, Captain James Cook described a tower-like rock outcrop in roughly the same location as that depicted on the Krenitsyn and Levashev map (Cook, 1785). Although the outcrop appears on the Chart of the N.W. Coast of America and the N.E. Coast of Asia (Roberts, 1794) and Cook refers to the Krenitsyn and Levashev map, he does not use a specific name for the outcrop. However, the name "Ship Rock" is attributed to Cook by Dall (1884). The Russian Orthodox Missionary Priest Ivan Veniaminov described an island that "rose from the sea" near the present location of Bogoslof Island in early May 1796 around the day known as the feast day of Pope St. John I (Wynne, 1913) or St. John's Day and thus the island received the name "Joanna Bogoslova" or John the Theologian's Island (Baker, 1906).

There are various indigenous names for Bogoslof Island including Agashagok (Grewingk, 1850), Agasaagux (newborn), and Tanaxsidaagux (newly made island; Bergsland, 1994). The name "Ostrov Ioanna Bogoslova" appears on a map published by Sarichev in 1826 and the name "Ostrova Bogoslova" was used in documents published by Captain Tebenkov in 1852. In the present context, Bogoslof volcano is an informal name that refers to the submarine edifice and its surface expression that today includes both Bogoslof Island and Fire Island.

\section{5-1806 Eruptive Period}

After the observations by Cook in 1778, nothing more about Bogoslof Island appeared in written reports until Georg Heinrich von Langsdorff, a German physician, scientist, and naturalist visited the region between 1804 and 1806. In his 1817 monograph, von Langsdorff described an "insulated rock" that was known by local Aleuts as a place with abundant "sea dogs" (seals) and sea lions suggesting that rock outcrops in the vicinity of present day Bogoslof Island were well known by local inhabitants (von Langsdorff, 1817). The apparently large numbers of marine mammals suggest that the island was more than an isolated rock outcrop. It is possible that the island included a larger, low relief section, which was suitable for supporting what may have been a large population of seals and sea lions.

People living on Unalaska and Umnak Islands remarked that sometime during 1795 a persistent layer of "fog" appeared over the Bogoslof area that did not disperse regardless of meteorological conditions (von Langsdorff, 1817). The fog described was so uncommon and consistent that people became afraid and would not approach the area by boat.

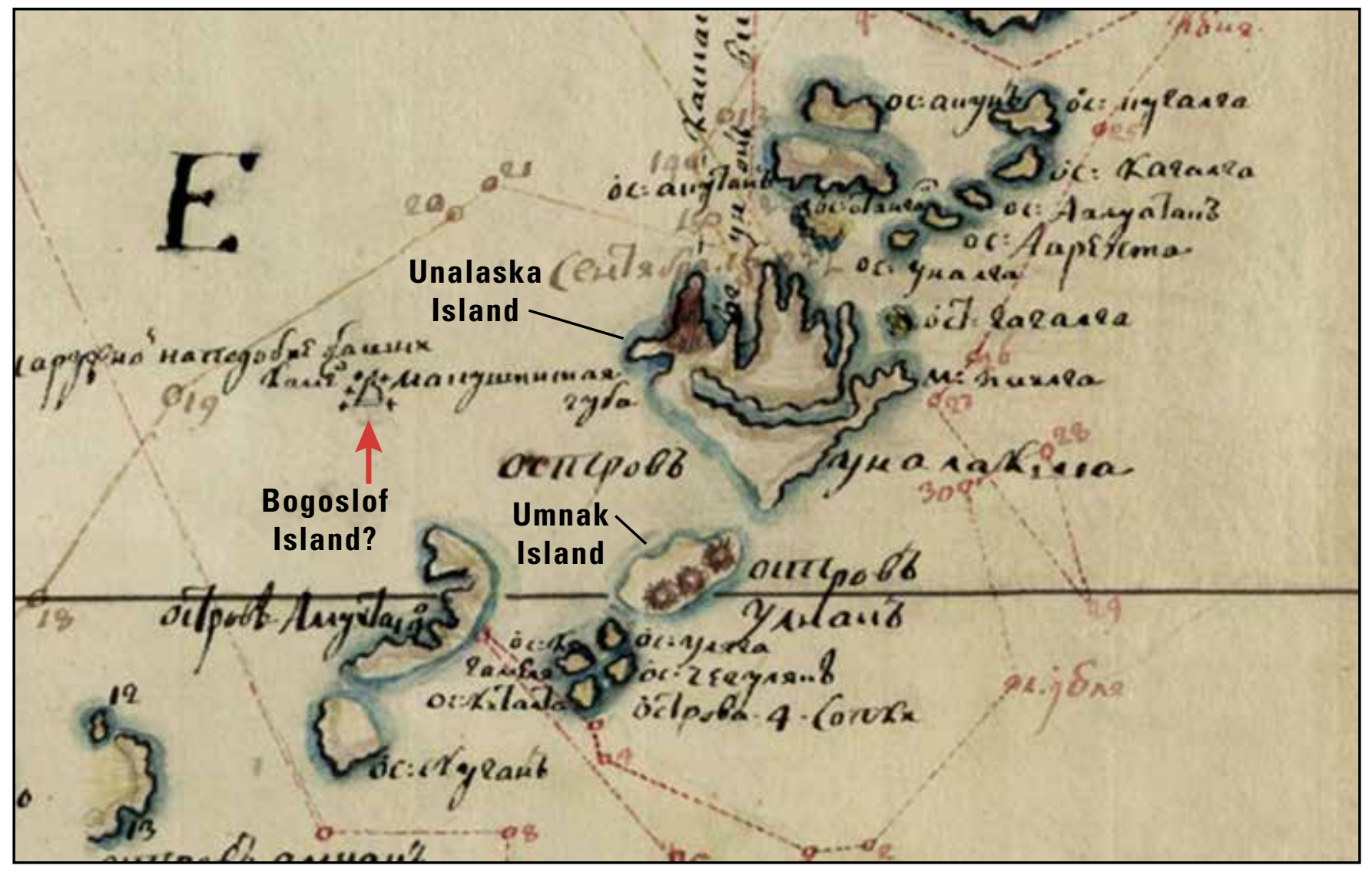

Figure 5. Portion of the 1772 map of the Krenitsyn and Levashev voyage (1768-69) showing the first known map depiction of an island in the vicinity of the present day Bogoslof Island. From the University of Alaska Fairbanks, Elmer E. Rasmuson Library. 
Eventually, a local Aleut ventured out to the insulated rock intent on harvesting some sea lions. The man returned "in the utmost terror and astonishment" and reported that the sea in the vicinity of the rock was boiling and that the fog was the "smoke or vapor" rising from the hot seawater. These observations suggest that magmatic heat, likely associated with shallow magma, was generating hot water and steam during 1795 , but it is not known if eruptive activity occurred as well. According to von Langsdorff (1817), the fog persisted for about 5 years, obscuring any clear views of the area, but when the fog eventually cleared, the insulated rock was no longer discernable and had been replaced by a larger island "resembling a chimney" that was emitting "fire and smoke".

Reports of eruptive activity at Bogoslof in early May 1796 were described to Otto von Kotzebue in 1816 by Ivan Kriukov (von Kotzebue, 1821) who was the manager of the Russian-America Company in Unalaska from 1813-21 (Hudson and Mason, 2014). Kriukov was on a hunting expedition with several others to Umnak Island and sometime between May 1-8, 1796, after several days of poor weather, he observed "a column of black smoke rising from the sea" northwest of his location (von Kotzebue, 1821). Kriukov also described a small, dark, low-relief object below the column of smoke (probably an island) and into the evening of May 8, 1796, observed "fire and flames" sustained and high enough to illuminate his location on the north side of Umnak Island. Kriukov also reported that strong earthquakes shook Umnak Island and a "terrible noise" was heard coming from the mountains to the south, which may have been an echo from the eruption of Bogoslof volcano. As the eruption continued, "stones" fell from the air around him and his hunting companions. By the morning of May 9, 1796, the activity had declined significantly and Kriukov and his party saw an island that had the "form of a black pointed cap" (von Kotzebue, 1821). This new island was later given the name "Old Bogoslof" (Jaggar, 1908a) and is known today as Castle Rock (fig. 3). Kriukov visited Umnak Island again in June 1796 and observed that the new island had continued to grow in size relative to its appearance about a month prior. Kriukov also described minor amounts of fire but considerably greater amounts of smoke occurring at the new island than he observed in May and that the shape of the island was variable and had changed since his visit in May. The observations of fire suggests the presence of incandescent rock at the surface or possibly that lava fountaining was occurring and the black smoke must have been sustained ash emissions. According to Kriukov's account, lava fountaining and ash emission continued for 4 years, but it was not until 1804 that anyone visited the island according to von Kotzebue (1821). When visited in 1804, areas of the new island were found to be too hot to stand on and much of the seawater around the island was warm. An unnamed Russian individual who had visited the island told von Kotzebue that the island was 2.5 miles (mi; $4 \mathrm{~km}$ ) in circumference and 350 feet ( $\mathrm{ft} ; 107 \mathrm{~m}$ ) high and that for "three miles around it, the sea was covered with stones" (von Kotzebue, 1821). This suggests that some of the eruptive products from the 1795-1804 eruptive period were low density pumiceous or scoriaceous material that remained floating on the sea. Von Kotzebue ends the narrative of his conversations with Kriukov and other local inhabitants of Unalaska by noting that about 100 fathoms $(\sim 180 \mathrm{~m})$ north of the new island "is a column of rock of considerable height which is mentioned by Cook." The column of rock must be the rock outcrop called Ship Rock that was observed and mapped by Krenitsyn and Levashev in 1768-69 and by Cook in 1778 .

Von Langsdorff (1817) provides an account of observations made during a visit to the new island by inhabitants of Unalaska in 1806. These individuals reported that the island had a circumference of about 30 versts $(19.8 \mathrm{mi}, 33 \mathrm{~km}$; 1 verst $=0.66 \mathrm{mi})$, which is considerably larger than that reported by von Kotzebue (1821). No estimate of the height of the new island was given, but the observers estimated that it would take roughly 5-6 hours to climb to the top. They witnessed an active lava flow on the north side of the island extending into the sea, but the area was too hot so they did not go ashore. The south side of the island was more hospitable and the visitors attempted to climb the lava dome from the south. They managed to climb about half way to the top but were turned around by the temperature of the cooling lava and hot steam emissions issuing from cracks and fissures in the lava dome. As von Langsdorff departed Unalaska, he had clear views of the new island and described it as a steep sided pinnacle. On the northwest side of the island he described four rounded summits that exhibited a step-like appearance.

Grewingk (1850) provides an account of eruptive activity in either 1804 or 1814 derived from Alexander Baranov's narrative of his travels in the Unalaska area. In this narrative, Baranov remarks that local inhabitants went to the Bogoslof area by boat and observed a small island "covered with small rocks, which are continuously expelled from the crater". This description suggests that coarse ejecta was being generated at the time of the visit and the volcano may have been in a state of low-level eruption; emission of ash is not mentioned. It is unclear how Baranov obtained this information as he was on Unalaska Island only in 1790. Grewink (1850) disputes the dates of the observations and favors an 1804 date, which is in agreement with other observations that describe eruptive activity then.

A chart of the Bogoslof area was published by Krusenstern in 1826 (fig. 6). It is unclear when the observations portrayed on the chart were made as Krusenstern did not reach the Bogoslof area during his voyage around the world in 1803-06. It is possible that the observations were made during the von Kotzebue voyage of 1815-18 as von Kotzebue spent considerable time at Unalaska and received numerous reports from local inhabitants about the eruptive activity. Other possible sources of information used to make the chart include von Langsdorff (1817) or Veniaminov (1840) who lived in Unalaska from 1824-34. Krusenstern's map is noteworthy because it shows a number of shallow outcrops and what appear to be as many as four nested lava domes on the southern part of the island south of Ship Rock (fig. 6). The lava dome or dome complex was later named Old Bogoslof by Jaggar (1908a) and is known today as Castle Rock (fig. 3). 

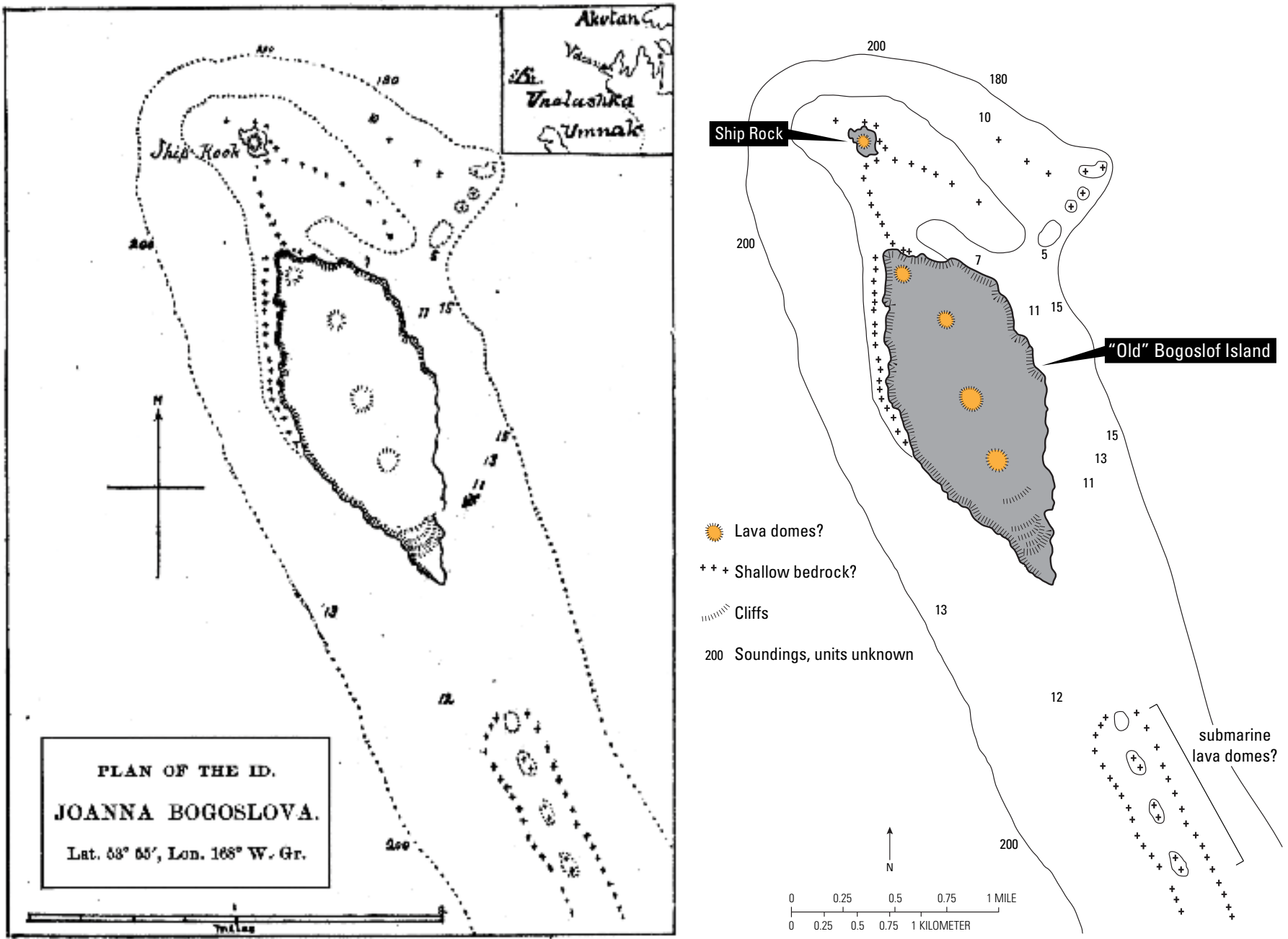

TLAX PROK KROЯRKATERN'B ATLA8, 1826.

Figure 6. Map of Bogoslof Island and Ship Rock, after Krusenstern (1826). Map on left is from Krusensterns Atlas; drawing on right is an interpretive, annotated version of Krusenstern's map. The date of the observations used to make the map are not known, but could be 1915 when von Kotzebue was in the Unalaska area. Note the pronounced northwest-southeast alignment of what appear to be lava domes. The numbers on the maps are probably soundings but the units are unknown. It is likely that the soundings are in fathoms (1 fathom $=6$ feet), which seems reasonable when compared to modern bathymetric data. 
Ship Rock and the dome-like features on Old Bogoslof are aligned to the northwest-southeast, a trend that persists to the present day.

The observations of eruptive activity between 1795 and 1806 (table 1) indicate that the volcano experienced intermittent periods of lava fountaining, ash emission, lava flows, and at least one episode of coarse tephra fall on Umnak Island. This period of eruptive activity was also associated with sustained steam emission and the eventual emplacement of a lava dome or domes (Old Bogoslof/Castle Rock) extending as much as $350 \mathrm{ft}$ above sea level.

Table 1. Summary of observations of eruptive activity and other phenomena at Bogoslof Island, 1795-2017.

[km, kilometer; $\mathrm{m}$, meter; $\mathrm{mm}$, millimeter]

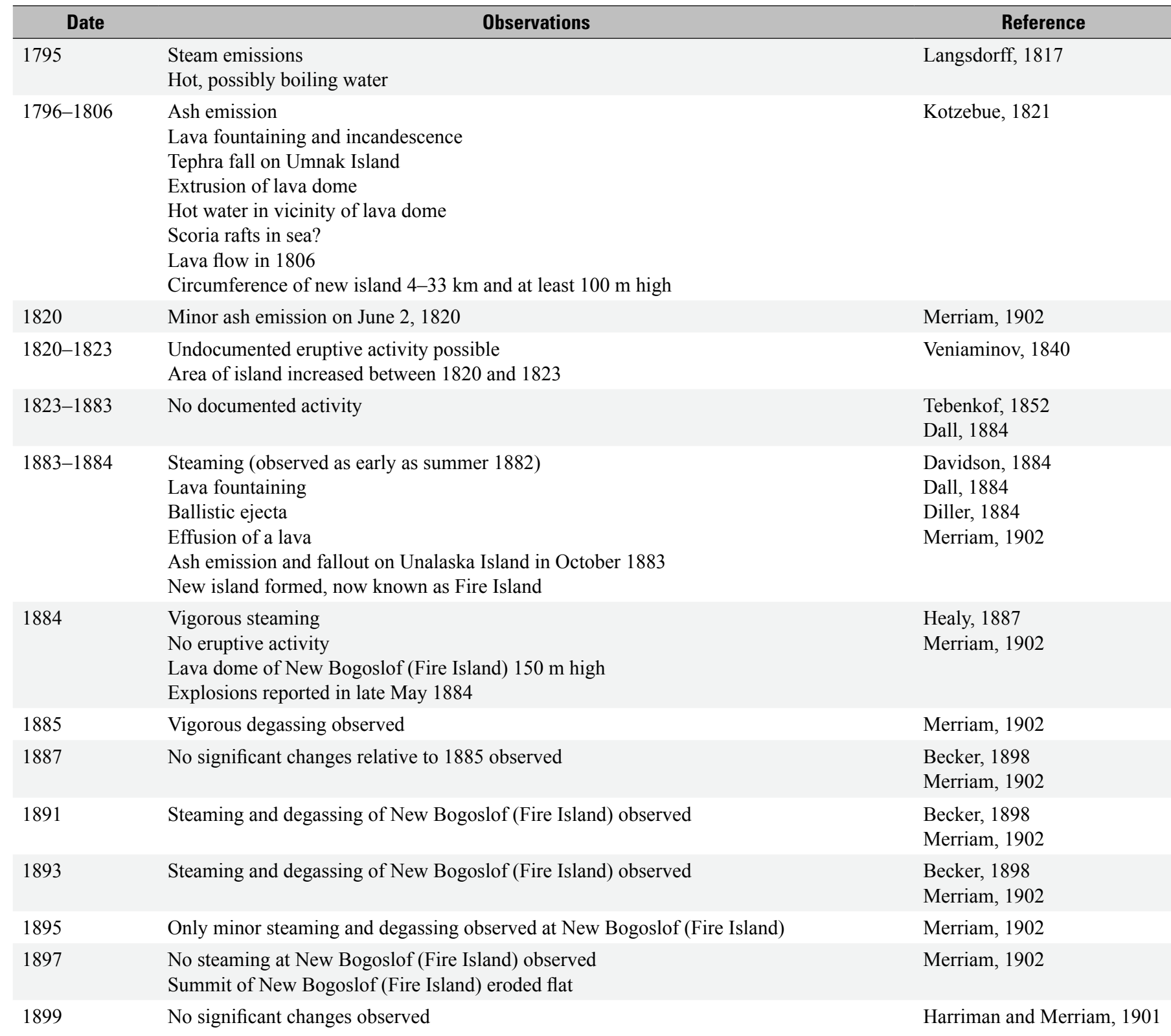




\begin{tabular}{|c|c|c|}
\hline Date & Observations & Reference \\
\hline 1904(?)-1908 & $\begin{array}{l}\text { New lava dome, } 90-120 \mathrm{~m} \text { high, located between Old Bogoslof (Castle Rock) and New } \\
\text { Bogoslof (Fire Island) observed in late May and in late July } 1906 \\
\text { New dome named Metcalf Cone } \\
\text { Dome inadvertently renamed Perry Peak in June } 1906 \\
\text { Local observers report that Metcalf Cone-Perry Peak was present in the winter of 1904-05 } \\
\text { A fourth island reported in spring, 1907, annexed to Metcalf Cone. New island named Mc- } \\
\text { Culloch Peak and about } 137 \text { m high and } 610 \mathrm{~m} \text { in diameter. } \\
\text { Effusion of McCulloch Peak was preceded by explosive destruction of part of Metcalf } \\
\text { Cone. This event or series of events also associated with explosively generated water } \\
\text { waves and ballistic ejecta. } \\
\text { Evidence for } 7.5 \text { m of uplift reported in 1906-07 } \\
\text { 5-6 mm of ash fall on the Dutch Harbor area, September 1, } 1907 \\
\text { McCulloch Peak destroyed by October 15, 1907 } \\
\text { Metcalf cone destroyed between mid-October } 1907 \text { and July } 1908 \\
\text { Possible tuff ring formed between Old and New Bogoslof (Castle Rock and Fire Island) } \\
\text { during September } 1907-\text { July } 1908 \text { activity } \\
\text { Large dome of water, vigorous steaming, ash emission, and lava effusion reported on July } \\
7,1908\end{array}$ & $\begin{array}{l}\text { Jordan and Clark, } 1906 \\
\text { Jaggar, } 1908 \text { b } \\
\text { Dunn, } 1908 \\
\text { Munger, } 1909 \\
\text { Prosser, } 1911\end{array}$ \\
\hline $1909-1910$ & $\begin{array}{l}\text { Lava dome effusion reported in September } 1909 \\
\text { Lava dome, } 54 \text { m high observed on June } 16,1909 \\
\text { New lava dome with crater at summit named Tahoma Peak } \\
\text { Ash emission, lava fountaining, and lightning observed on September 18, } 1910 \\
\text { Heat from the dome felt as far away as } 9.5 \mathrm{~km}\end{array}$ & $\begin{array}{l}\text { Prosser, } 1911 \\
\text { Powers, } 1916\end{array}$ \\
\hline $1911-1926$ & $\begin{array}{l}\text { Unconfirmed report of steam and ash emission in July } 1913 \\
\text { No activity observed in September } 1914 \\
\text { No activity observed in } 1920 \\
\text { Top of Old Bogoslof (Castle Rock) reported to be } 120 \mathrm{~m} \text { above sea level and surrounded } \\
\text { by an uplifted wave-cut platform in September } 1922 \\
\text { No activity observed in July } 1923 \\
\text { No activity observed in late May } 1926\end{array}$ & $\begin{array}{l}\text { Powers, } 1916 \\
\text { Morris, } 1936\end{array}$ \\
\hline 1927 & $\begin{array}{l}\text { Minor lava effusion observed on July } 6,1927 \\
\text { Undocumented eruptive activity, lava effusion and steaming observed in late 1927. New } \\
\text { lava dome located at former site of Metcalf Cone and McCulloch Peak. }\end{array}$ & $\begin{array}{l}\text { Jaggar, } 1927,1930 \\
\text { Morris, } 1936\end{array}$ \\
\hline 1931 & "Fire" at Bogoslof reported on October 31, 1931 & Jaggar, 1932 \\
\hline 1935 & Hydrographic survey completed; no eruptive activity observed & Morris, 1936 \\
\hline 1947 & Geologic investigations by F.M. Byers, Jr.; no eruptive activity observed & Byers, 1959 \\
\hline 1992 & $\begin{array}{l}\text { Steam and ash emissions observed on July } 6,1992 \\
\text { Relatively continuous ash emission observed on July } 14-15,1992 \\
\text { Steam and ash plume observed on July } 20,1992 \text {, reaching as high as } 8 \mathrm{~km} \text { above sea level } \\
\text { Effusion of lava dome on the northeast sector of Bogoslof Island observed on July } 24 \text {, } \\
\text { 1992. }\end{array}$ & McGimsey and others, 1995 \\
\hline 1994 & $\begin{array}{l}\text { Geologic investigations by M. Harbin; No eruptive activity observed. } \\
1992 \text { lava dome estimated to be } 275 \mathrm{~m} \text { in diameter and } 150 \mathrm{~m} \text { high. }\end{array}$ & Harbin, 1994 \\
\hline $2016-17$ & $\begin{array}{l}\text { Steam and ash emissions documented between December 12-14, } 2016 \\
\text { At least } 64 \text { eruptive events between December 14, 2016, and August 30, } 2017\end{array}$ & www.avo.alaska.edu \\
\hline
\end{tabular}




\section{Eruptive Activity}

On June 2, 1820, the Bogoslof area was visited by Captain Shishmaref in command of the Russian sloop Good Intent. Onboard, a Dr. Stein made observations of a column of smoke rising from the highest point of the island, suggesting that minor steam and ash emissions were occurring. No other activity was noted, except that the island was described as "a cold rock that had ceased to grow" (Merriam, 1902).

\section{Observations Between 1820 and 1883}

There are no known observations of eruptive activity after the 1820 report in Merriam (1902) and prior to the eruption of 1883. However, several individuals who were in the region during this period contributed observations. Veniaminov (1840) comments that the island ceased to increase in size until 1823, suggesting that there may have been minor or no eruptive activity occurring between 1820 and 1823 .

A sketch of Bogoslof Island made in 1832 by Captain Mikhail Dmitrievich Tebenkof (fig. 7) was included in a monograph by Count Friedrich Lütke (Lütke, 1836) who was in Unalaska in 1827. Tebenkof was a Russian surveyor who was in the Bering Sea area from 1831 to 1833 . In addition to his sketch of Bogoslof, he produced an atlas of the northwest coasts of America from the Bering Strait to Cape Corrientes and the Aleutian Islands (Tebenkof, 1852). Tebenkof's sketch shows a jagged, pyramid-shaped rock mound and a much smaller isolated pinnacle. The rock mound is probably the lava dome extruded during eruptive activity in 1796 (Old Bogoslof/Castle Rock) and the pinnacle is likely the rock observed and mapped by Krenitsyn and Levashev (Shavanov, 1772) and by Cook (1785) and generally known as Ship Rock. Tebenkof estimated that the larger outcrop was about $457 \mathrm{~m}(1,500 \mathrm{ft})$ high and had a circumference of not more than $3.7 \mathrm{~km}$ (2 nautical miles).
William Healey Dall visited Bogoslof several times, in 1872, 1873, and 1899 as a member of the Harriman Expedition. He provided numerous observations in a series of reports beginning in 1884. Apparently Dall's party attempted to land on the island in both 1872 and 1873 without success. However, Dall made several sketches of the island (Dall, 1884) that show a profile and characteristics similar to that reported by Tebenkof in 1832.

\section{3-84 Eruptive Activity}

Local inhabitants reported that a new eruption at Bogoslof was first noticed in May 1883 although steaming at Bogoslof Island was noted by local observers as early as the summer of 1882 (Merriam, 1902). On September 27, 1883, the schooner Matthew Turner, with Captain Anderson at the helm, passed Bogoslof Island and observers reported that the island was surrounded by "white smoke, like steam" (Davidson, 1884). During the evening of September 27 observers on board the Matthew Turner reported seeing fire on Bogoslof Island from a distance of about $25 \mathrm{mi}$ (Davidson, 1884; Merriam, 1902). They also observed ballistic ejecta, eruption of "large masses of heated rock," and ash and steam emission from "numerous fissures" on the top, sides, and underwater of what was probably a lava dome (Merriam, 1902).

One month later, on October 27, Captain Hague on the steamer Dora passed within a mile of Bogoslof Island and observed "black smoke" resembling burning tar issuing from what he interpreted to be a new island consisting of a steep rocky pinnacle (fig. 8; Davidson, 1884). Captain Hague, after his visit in October 1883 proposed the name New Bogoslof for the volcanic island he observed. Dall (1884) proposed the name Grewingk for the new volcanic island in honor of Constantine Grewingk for his compilation of early observations of Bogoslof (Grewingk, 1850). Both names are used in historical literature.

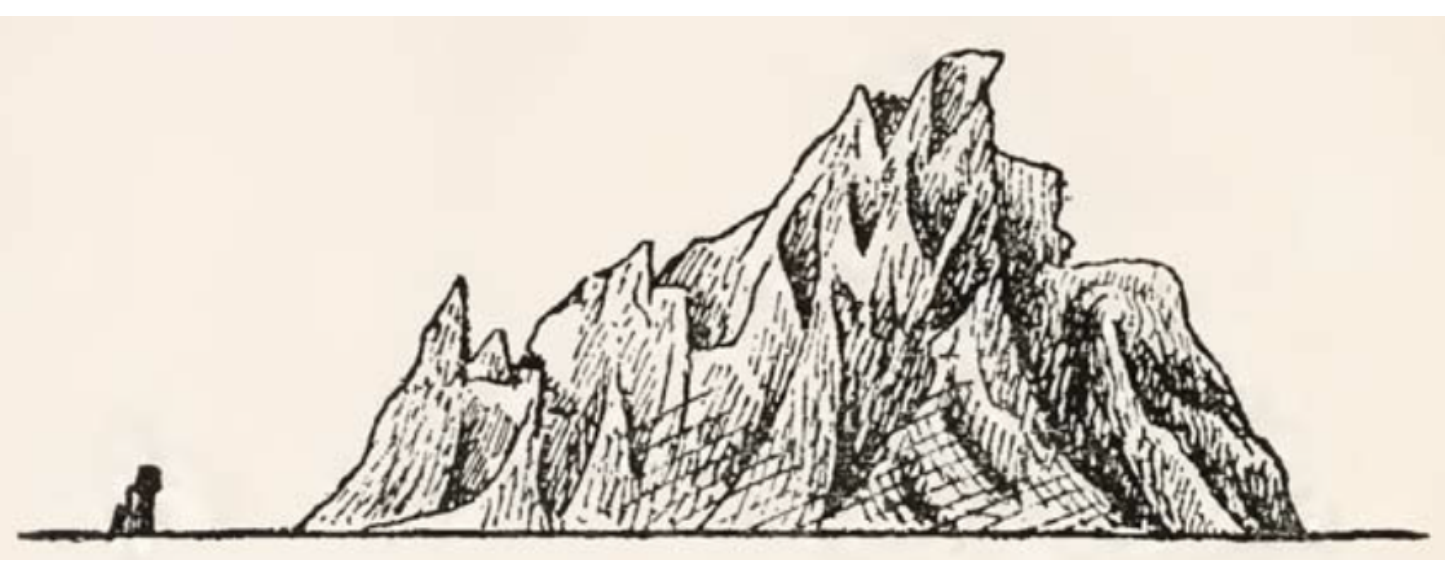

Figure 7. Sketch of Bogoslof Island by M. Tebenkof in 1832 (Lutke, 1836). The larger, jagged-appearing rock outcrop on the right, reported by Tebenkof to be about 1,500 feet high with a circumference of about 2 nautical miles (Lutke, 1836) was likely emplaced during eruptive activity in 1796. The smaller rock pinnacle on the left is probably the outcrop observed by Krenitsyn and Levashev (fig. 5) and also observed by Cook (1778). 


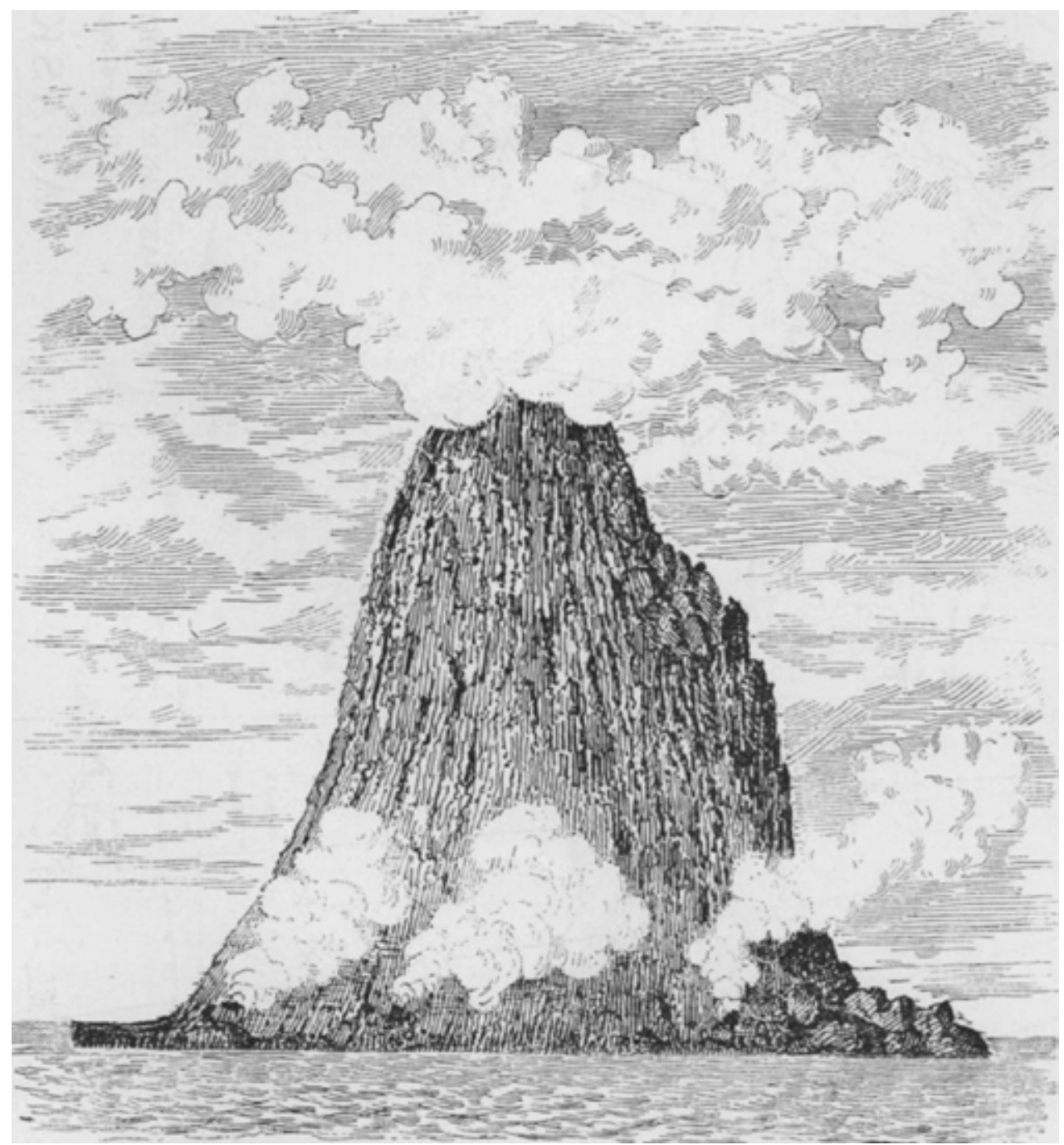

Figure 8. Hand drawn sketch of Bogoslof Island by G. Davidson based on descriptions provided during interviews with Captains Anderson and Hague who observed this feature in September-October 1883 (Davidson, 1884). The height of the rock pinnacle above sea level was estimated to be $800-1,200$ feet (244-366 meters).

Observers on the Dora thought that the island appeared larger than described in previous reports and that the new island located about $0.5 \mathrm{mi}$ north-northwest of the old island (Ship Rock) was irregular in profile, rose 500-800 ft (152-244 $\mathrm{m}$ ) above sea level, and was about $0.75 \mathrm{mi}$ in diameter (Dall, 1884; Davidson, 1884). Observers on the Dora also reported vigorous steaming from the base of the rock pinnacle and remarked that at night the island appeared "on fire," suggesting incandescence or possibly that lava fountaining may have been occurring. Captain Hague further described Bogoslof Island as being enveloped in "smoke and flame" with "red-hot lava issuing from its central portion and great quantities of softer lava running down to the sea" (Dall, 1884). Although the specific timing of eruptive activity is not known, Dall (1884) indicates that the type of activity observed by Hague in October 1883 continued into 1884.

Dall (1884) also reports on the darkening of the sky and the blocking of sunlight by a dark cloud in the sky north of Unalaska on October 16, 1883. He described the fall of ash on Unalaska as a covering of "dull gray cottony ashes of extreme lightness." Dall (1884) also makes reference to another account of ash fall on October 24 but provides no further details. Reports of ash fall were also described in Davidson (1884) who reported that sometime between October 16-20, 1883, inhabitants of Iliuliuk (present day Dutch Harbor/ Unalaska) reported "a shower of ashes."

Diller (1884) provides a slightly more detailed description of the ash fall and indicates that it occurred on October 20, 1883. A Mr. Applegate, the signal-service operator at Unalaska, reported that at about 2:30 p.m. local time, "the air became suddenly darkened, like night; and soon after, a shower of mixed sand and water fell for about ten minutes, covering the ground with a thin layer" (Diller, 1884). In the village of Unalaska, windows were coated with ash thick enough to make it impossible to see out. Diller (1884) received a sample of the ash for analysis and reports that the sand-size ash was mostly crystalline fragments dominated by feldspar crystals. Diller commented that most of the ash particles were irregular, angular "splinters" (fig. 9), but also included euhedral crystals with inclusions as large as about 0.15 millimeter $(\mathrm{mm})$ in diameter (Diller, 1884). Other minerals present in the sample included pale green augite, hornblende, and irregular grains and crystals of magnetite. Clear volcanic glass was rare. A chemical analysis of the ash was made by T.M. Chatard of 
the U.S. Geological Survey who found that the silica content was 52.48 percent (Diller, 1884).

\section{Observations}

On May 21, 1884, the Revenue Marine steamer Corwin under the command of Captain Michael A. Healy visited Bogoslof Island and contributed several observations, including a map and photographs of the island (Healy, 1889). Although vigorous steaming on New Bogoslof (later known as Fire Island) was observed, the volcano did not appear to be actively erupting. A report prepared by Second Lieutenant John C. Cantwell provides descriptions and observations obtained when Cantwell and a reconnaissance party landed on Bogoslof Island by small boat. Cantwell reports that the two masses of rock on the island, Old and New Bogoslof (figs.
10-12), were connected by a narrow, low-relief isthmus composed of "a mixture of fine black sand and small oolitic stone". It is unclear what was meant by the term oolitic stone, but it is possible that Cantwell had observed accretionary lapilli produced during the 1882-84 eruptive period. Cantwell also describes the ash deposits around the island as being crusted on the surface, but soft, loose, and easily lofted below the crust and being "knee deep" (Healy, 1889). Cantwell climbed the lava dome of New Bogoslof and estimated the temperature within a crack near the top of at least $500^{\circ} \mathrm{F}$. He observed sulfur deposits along many of the cracks in the fractured lava dome and vigorous emission of volcanic gasses that produced a "suffocating and nauseating" reaction. Cantwell performed a visual inspection of the ash on Bogoslof Island and compared it to ash samples collected at Unalaska and found the samples to be identical (Healy, 1889).

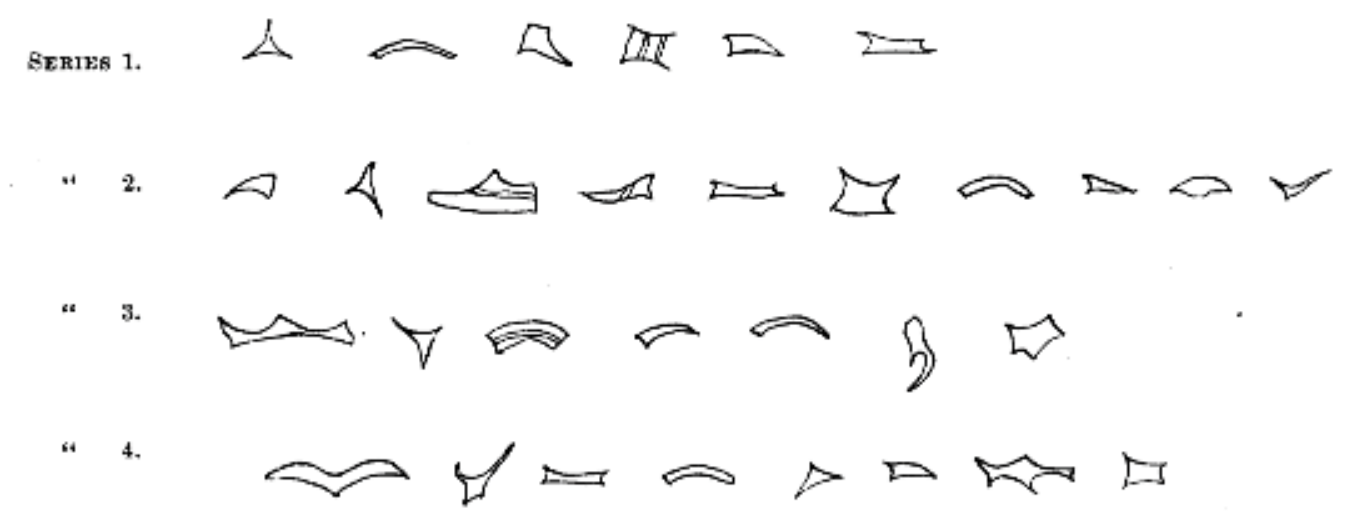

Figure 9. Outlines of sand-sized ash particles from the October 20, 1883, ash fall on Unalaska. From Diller (1884).

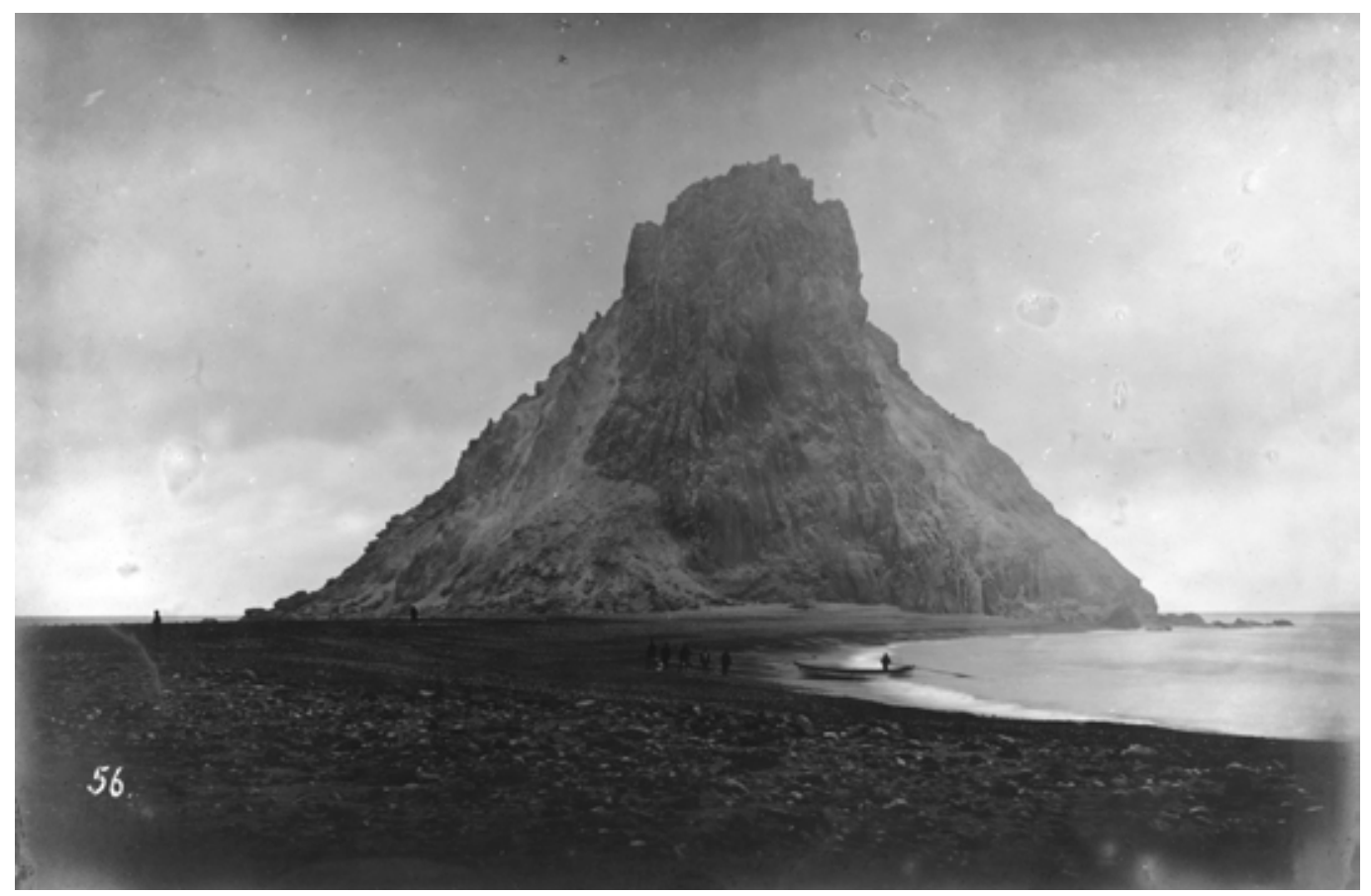

Figure 10. Photograph of Old Bogoslof, May 21, 1884. View is to the southeast from the spit connecting New and Old Bogoslof. Photograph by Lieutenant George H. Doty. 


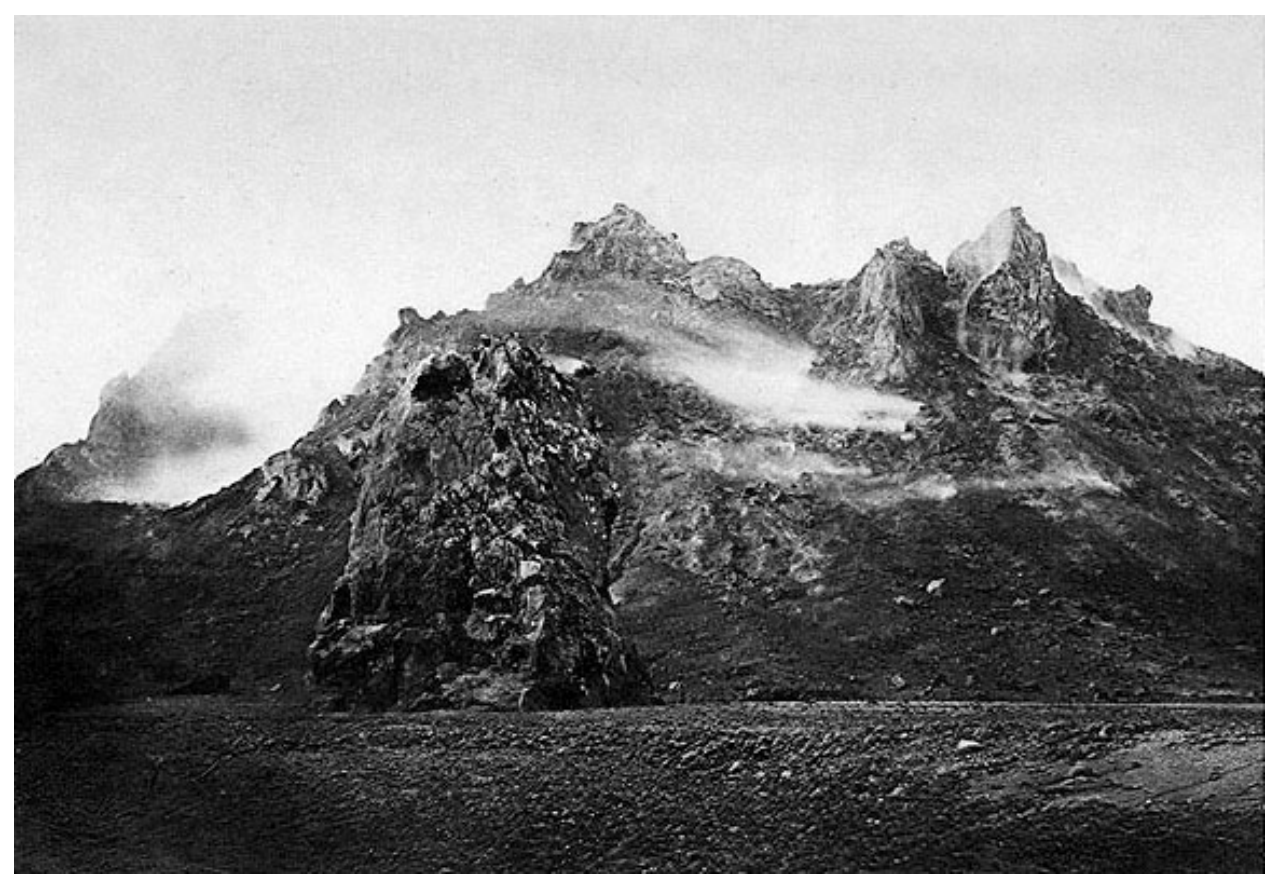

Figure 11. Photograph of New Bogoslof and Ship Rock (in foreground), May 21, 1884. View is toward the northwest. Photograph by Lieutenant George H. Doty.

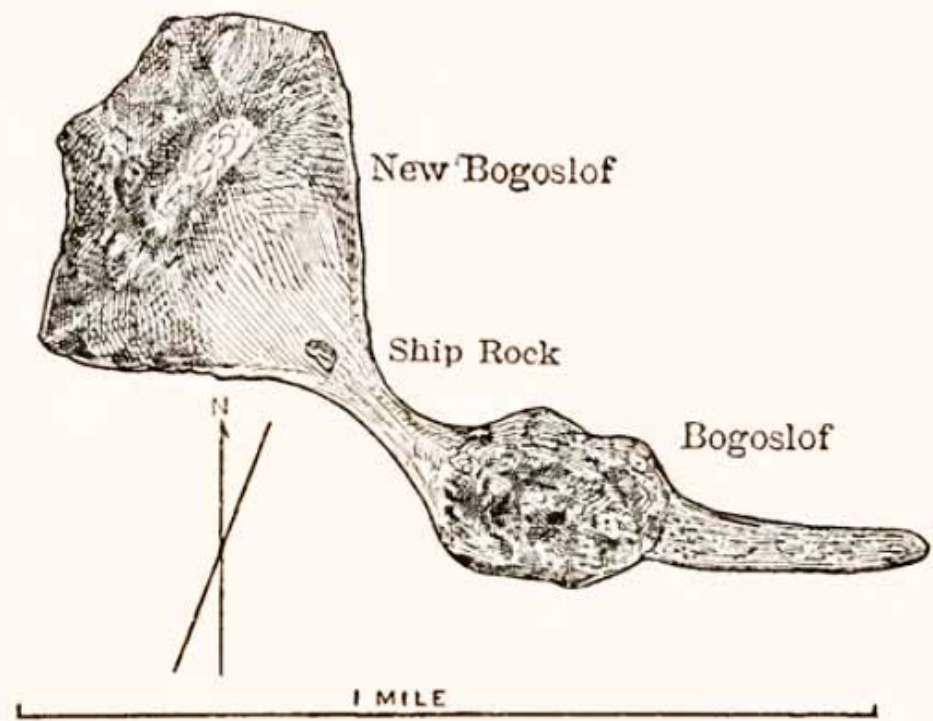

Figure 12. An 1884 map of Bogoslof Island showing Old Bogoslof, Ship Rock, and New Bogoslof, which was a result of eruptive activity between 1882 and 1884 . This map was drawn by Captain Cantwell who was aboard the Revenue Steamer Corwin, which visited the area in 1884 (Merriam, 1902).

In a second report, by H.W. Yemans, a surgeon on board the Corwin, loose volcanic ash deposits are described as covering parts of the lava dome of New Bogoslof (Fire Island), suggesting that the lava dome was emplaced prior to or during an episode of ash emission. Yemans describes some of the dome rock as "aqueo-igneous conglomerate," which may indicate the presence of agglutinate and welded spatter. He also mentions finding "a few fragments of granitoid rock" within the rubble on the dome flank, which may be components of the wall rock within the Bogoslof edifice.
Additional information acquired by the landing party dispatched to Bogoslof from the Corwin, but not included in the Healy (1889) report, was later compiled by Merriam (1902). According to these observations, the height of the New Bogoslof lava dome was estimated at $500 \mathrm{ft}(150 \mathrm{~m})$ above sea level and characterized by a "great fissure" along its upper third, oriented in a northeast-southwest direction. It was not possible for the landing party to reach the fissure because of the high temperature of the lava and the vigorous emission of gasses. Merriam (1902) commented that the feature known as 


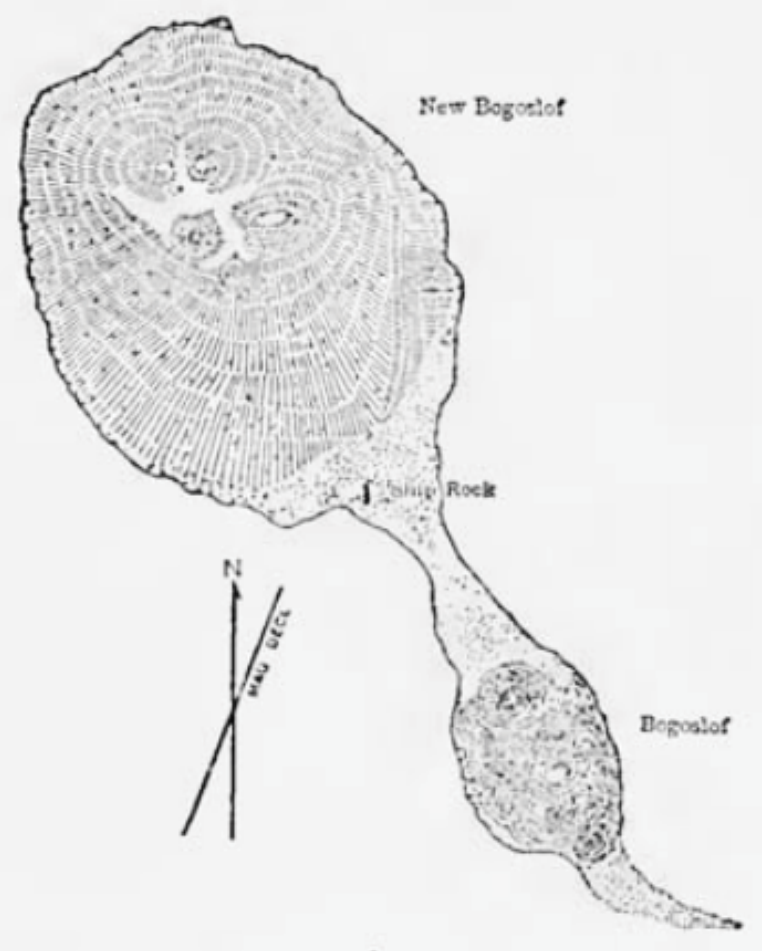

Figure 13. Map of Bogoslof Island made by G.M. Stoney based on observations made in late May 1884. From Merriam (1902).

Ship Rock, and likely the same outcrop observed by Krenitsyn and Levashev, and Cook in the late 1700s, was still present but exhibited water marks and barnacle lines that were more than $20 \mathrm{ft}(6 \mathrm{~m})$ above sea level indicating that the feature had been uplifted relatively recently.

On May 28, 1884, a U.S. Navy hydrographic ship reached Bogoslof and Lieutenant George M. Stoney provided some additional observations and a map of the island (Merriam, 1902; fig. 13). Stoney reported that the temperature of ash deposits just below the surface was $250^{\circ} \mathrm{F}$ and that parts of the lava dome were hot enough to ignite wood (sticks) immediately. Stoney reported that numerous earthquakes were felt, many accompanied by rumbling sounds and occasional explosions, during his 3-day visit to the island (Merriam, 1902). Gas emissions below sea level around New Bogoslof produced a bubbling, boiling appearance, but no elevated water temperatures were observed.

\section{Observations}

On return visits to Bogoslof on June 19 and September 15,1885 , observers on the Corwin reported that vigorous outgassing at the summit of New Bogoslof continued, little changed from the previous year. Views of the summit of New Bogoslof from the north were described as a "bright sulphurous light" emanating from "rifts" in the side of the lava dome
(Merriam, 1902). These observations are suggestive of incandescence of the still hot core of the lava dome.

\section{Observations}

A sketch of Bogoslof Island made by W.C. Greenfield in 1887 (Becker, 1898; Merriam, 1902) shows a configuration similar to that observed in 1884 and 1885. Merriam (1902) comments that based on the Greenfield sketch, Bogoslof appeared to be slightly higher than when observed in $1884-85$, but this could be a result of low tide at the time Greenfield made a sketch of the island.

\section{1 and 1893 Observations}

The U.S. Fish Commission steamer Albatross visited Bogoslof in 1891 and several photographs and sketches were made of both New and Old Bogoslof (Becker, 1898; Merriam, 1902). The photographs are of poor quality and do not show anything noteworthy except that New Bogoslof appears to be steaming in one of the photographs (fig. 14). By 1891, Ship Rock and the low-relief isthmus connecting Old and New Bogoslof had been eroded away (fig. 15; Becker, 1898; Merriam, 1902). In August 1891, C. Hart Merriam and Thomas C. Mendenhall visited Bogoslof Island aboard the Albatross and reported significant steaming and degassing at New Bogoslof, including localized sulfur-laden steam jets. Steaming and degassing were also observed in 1893 by Captain Tanner of the Albatross (Merriam, 1902).

\section{Observations}

George F. Becker, William H. Dall, and Chester W. Purington of the U.S. Geological Survey visited Bogoslof Island in August 1895. Becker (1898) reported that the two islands (Old and New Bogoslof) were separated by about $0.75 \mathrm{mi}(1.2 \mathrm{~km})$ of open ocean and the intensity of steam and gas emissions from New Bogoslof had declined significantly since the 1891 visit by Merriam and Mendenhall (Merriam, 1902). The profile of New Bogoslof (Fire Island) also appeared to have a distinctly plateaulike form (Merriam, 1902). Purington took several photographs of both Old and New Bogoslof, two of which are shown in figures 16 and 17. A sketch map of the area was produced by W.H. Dall (fig. 18).

\section{Observations}

Leonhard Stejneger of the International Fur Seal Commission was in the Bogoslof area in 1897 and took several photographs of Bogoslof Island. Sketches made from these photographs appear as figures 30 and 31 in Merriam (1902). There is no indication of steaming or gas emissions in these sketches (fig. 19). 


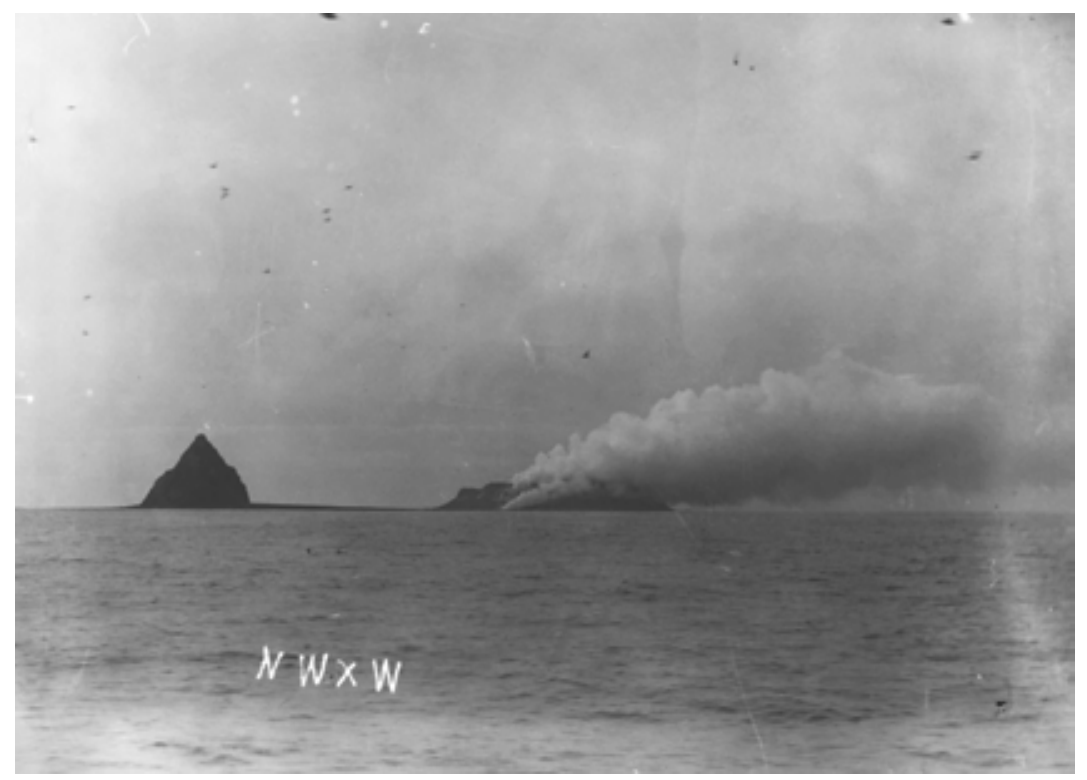

Figure 14. Photograph of steam emissions from New Bogoslof Island, August 11, 1891. Old Bogoslof Island on left. Photograph by C. Hart Merriam.

Figure 15. Sketch map of Old and New Bogoslof Islands in 1891 by C. Hart Merriam, showing new spit extending northwest of Old Bogoslof and absence of spit connecting Old and New Bogoslof; compare with figures 12 and 13. From Merriam (1902).

Figure 16. Photograph of Old Bogoslof Island, August 13, 1895. View is toward the northwest; see figure 18 for approximate orientation. The material in the middle foreground is stratified and may be tephra fall and flow deposits associated with the 1882-84 eruptive activity that formed New Bogoslof. Photograph by C.W. Purington, U.S. Geological Survey. 


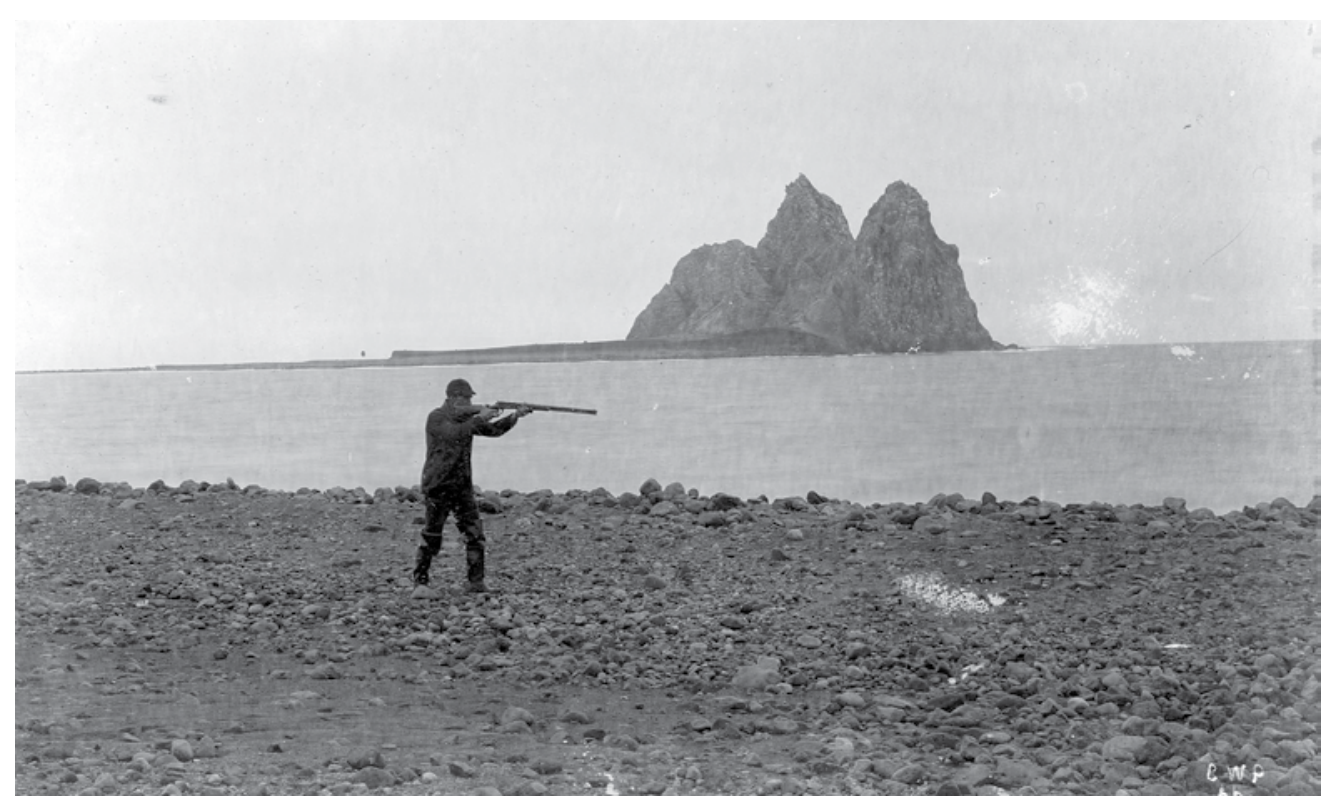

Figure 17. Photograph of Old Bogoslof, August 13, 1895. View is toward the southeast from New Bogoslof; see figure 18 for approximate orientation. Wedge of dark material at the base of the outcrop are probably tephra and pyroclastic flow deposits associated with the 1882-84 eruptive activity that formed New Bogoslof. Photograph by C.W. Purington, U.S. Geological Survey.

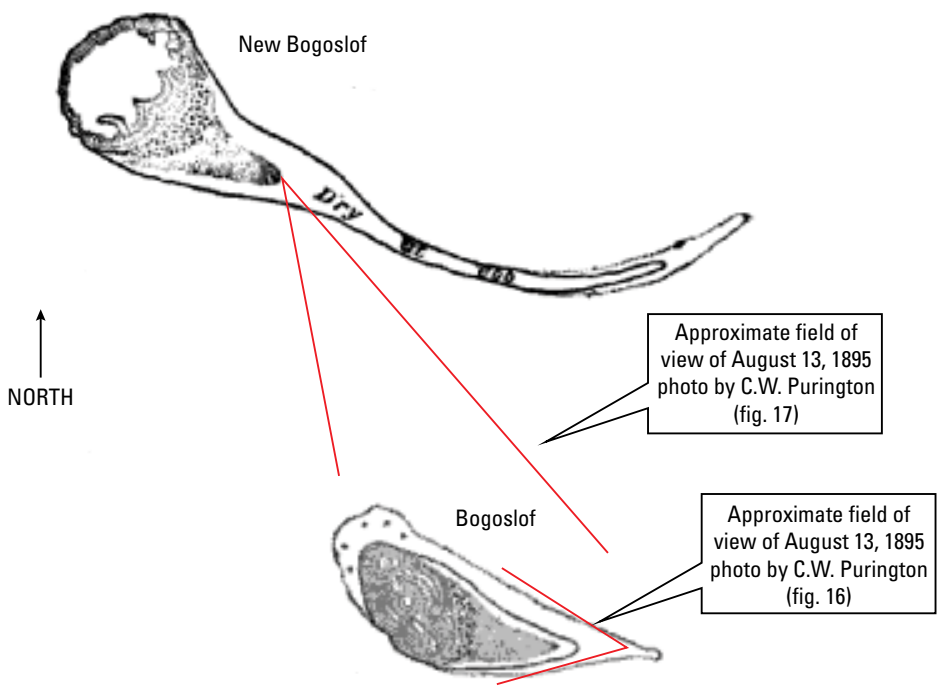

0

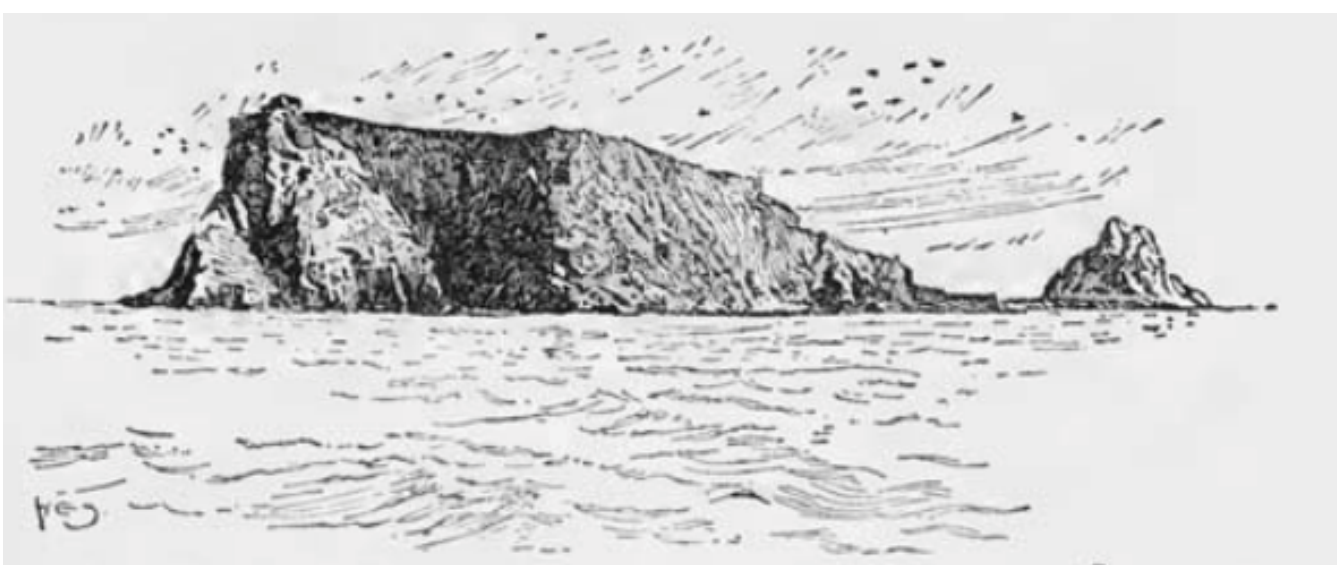

Figure 18. Sketch map of Old and New Bogoslof Islands, made in 1895 by W.H. Dall. From Merriam (1902).
Figure 19. Sketch of New Bogoslof (on left) and Old Bogoslof (on right) made from photograph taken by L. Stejneger, June 30, 1897. Note the level, plateau-like form of New Bogoslof, which presumably resulted from surface erosion of the outcrop. From Merriam (1902). 


\section{Observations}

The Bogoslof area was visited in July 1899 by the Harriman Expedition to Alaska and is described in Harriman and Merriam (1901). Although members of the expedition were not able to land on any part of Bogoslof Island, photographs (fig. 20) and observations made indicate that the island had changed little from the previous several years.

\section{4(?)-08 Eruptive Activity}

On May 29, 1906, the U.S. Bureau of Fisheries steamer Albatross reached Bogoslof Island and Lieutenant Commander LeRoy M. Garrett reported that a new volcanic island had developed between Old and New Bogoslof, was conical in form, and steaming profusely (Jaggar, 1908b). He also described a rock spire or "horn" at the summit of the lava cone. Garrett proposed the name Metcalf Cone for the new island in honor of Victor H. Metcalf, the U.S. Secretary of Commerce and Labor. Dr. Charles H. Gilbert of Stanford University was also aboard the steamer Albatross and reported that the new cone was about $300 \mathrm{ft}$ high and consisted of jagged, sulfur encrusted lava (Jordan and Clark, 1906).

In June 1906 the U.S. Revenue cutter Perry reached the Bogoslof area (Munger, 1909). Observers on board also reported that a new island had formed and named it Perry Peak (fig. 21), not knowing that Lieutenant Commander Garrett had already proposed the name Metcalf Cone. On July 10, 1906, the U.S. Revenue cutter Thetis was in the vicinity of Bogoslof Island and observers on board reported thick vapor emissions from the new island between Old and New Bogoslof (fig. 22).

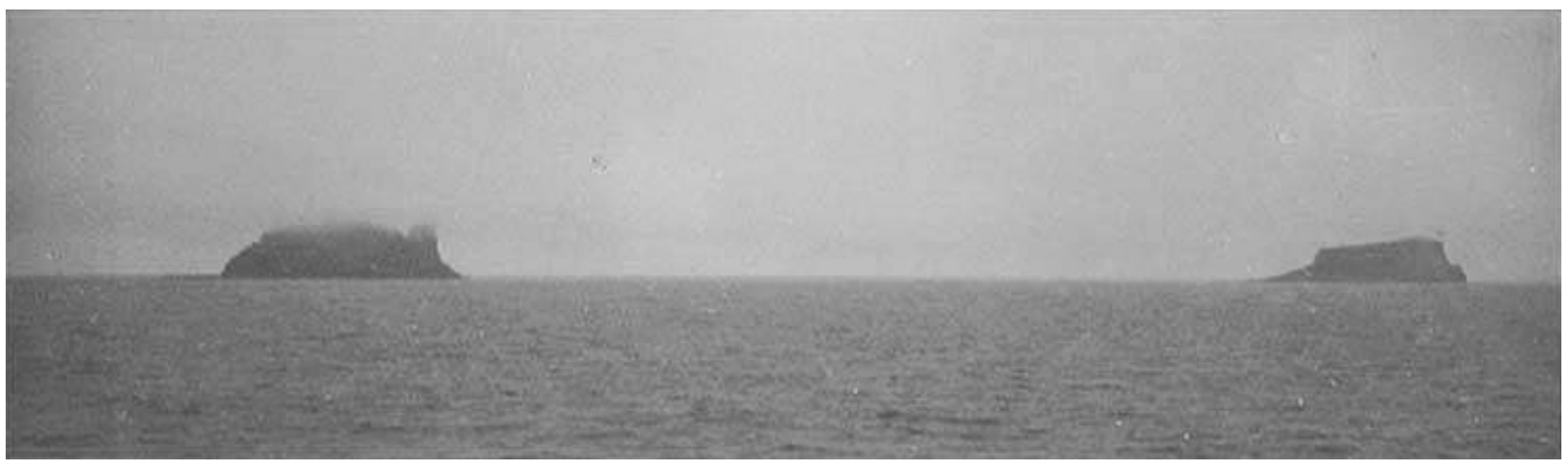

Figure 20. Photograph of Old Bogoslof (on left) and New Bogoslof (on right), July 8, 1899. The distinctive plateau-like form of New Bogoslof is also apparent in this photograph. In this view, New Bogoslof appears smaller than Old Bogoslof, which may mean that it is was eroding more rapidly than Old Bogoslof. Compare with figure 18. Photograph by W.B. Devereux.

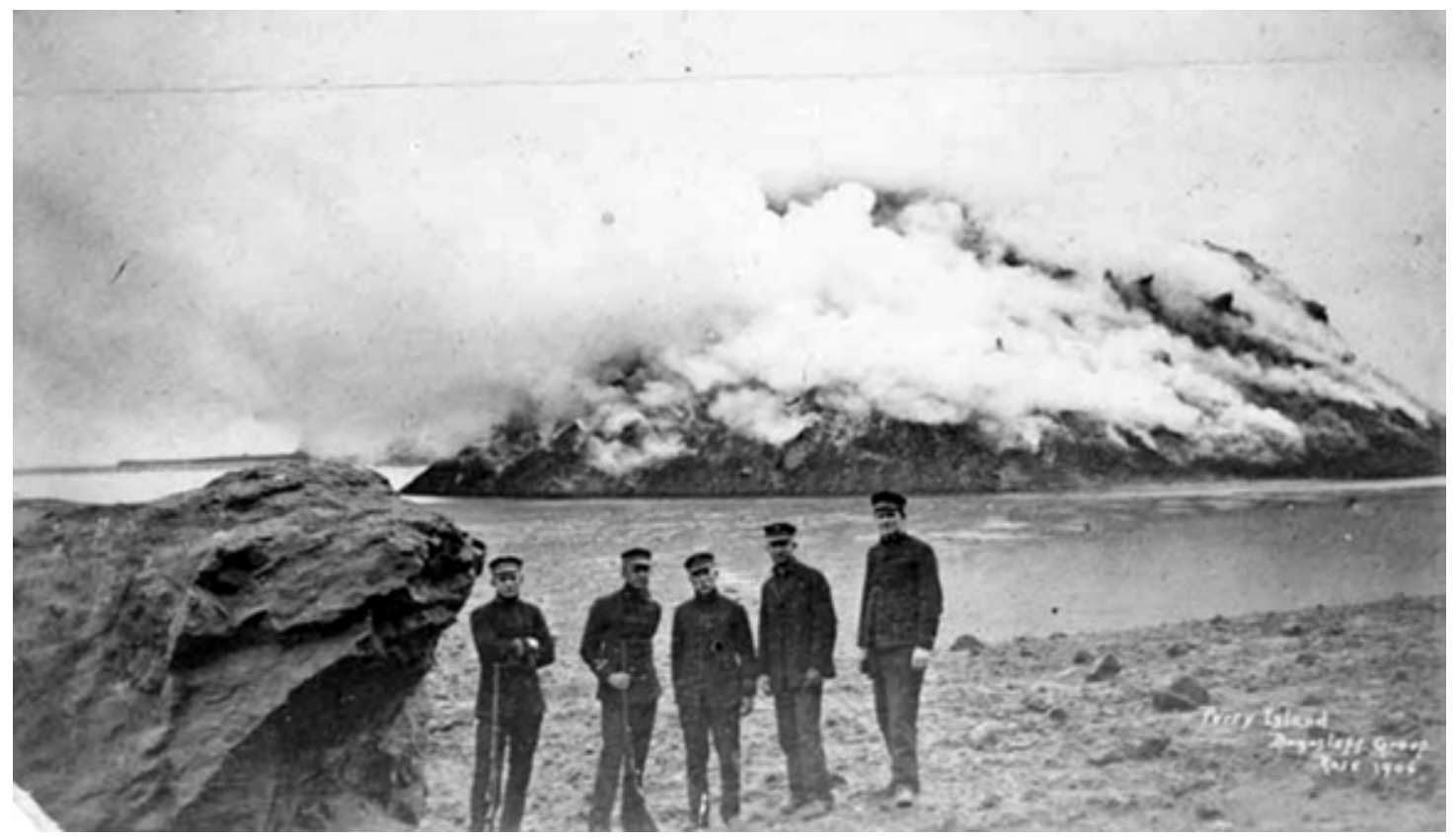

Figure 21. Photograph of 1906 lava dome from New Bogoslof when visited by crewmen of the U.S. Revenue steamer Perry, July 29, 1906. View is toward the south and New Bogoslof is in front of the five sailors. Photograph by Captain F.M. Munger. 


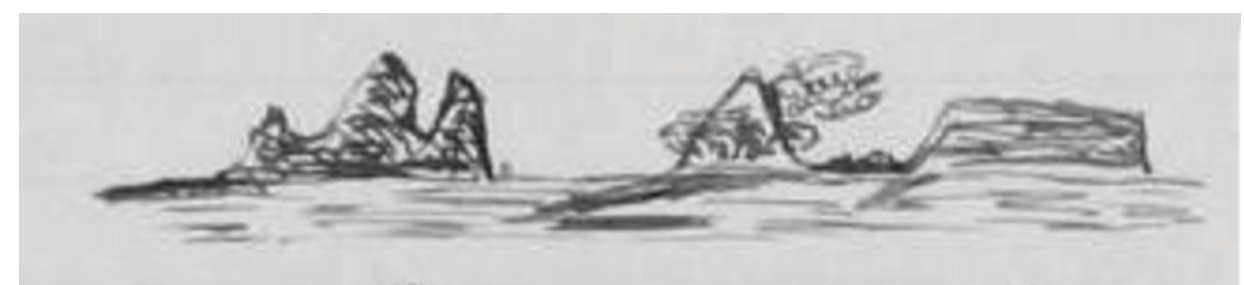

Old Bogoslof

1906 lava

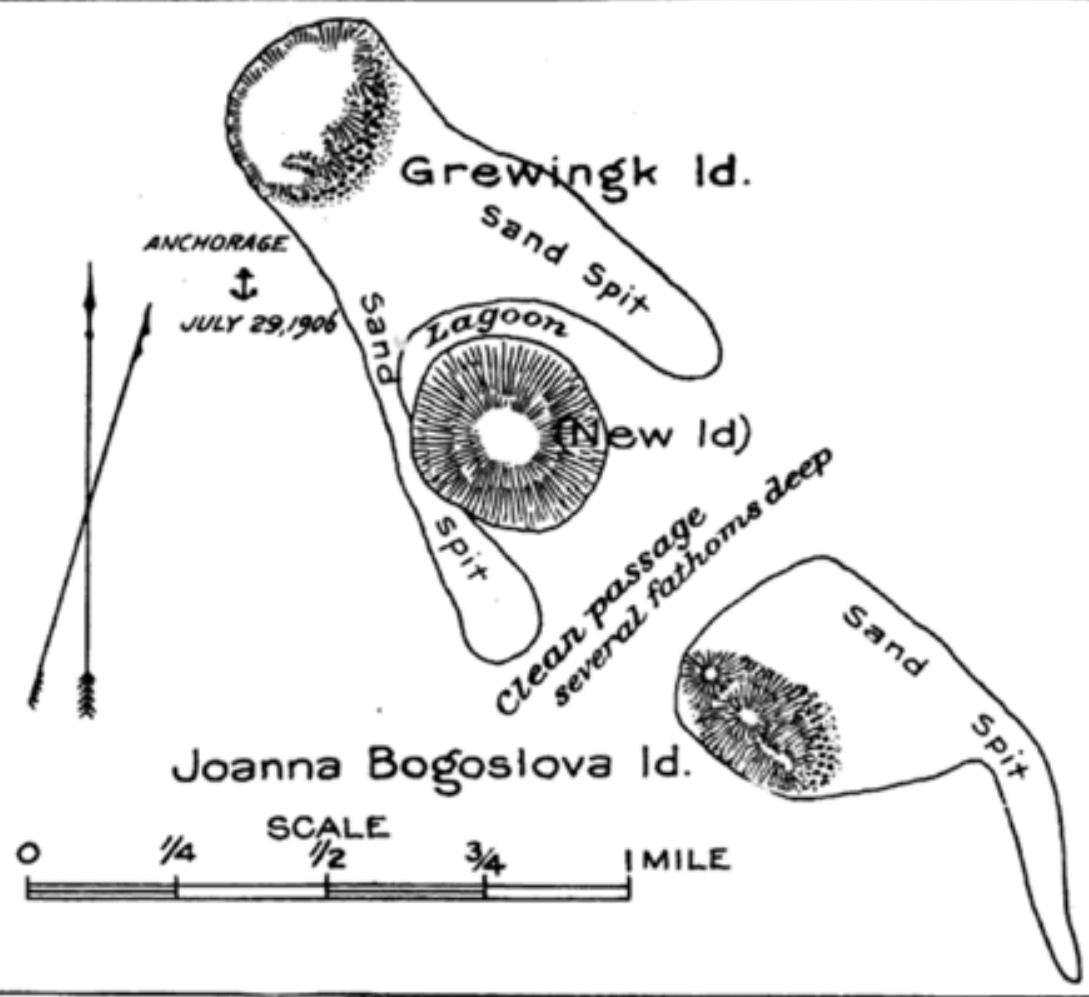

Figure 22. Sketch of lava dome erupted in 1906 as observed by sailors on board the Revenue cutter Thetis, July 10,1906 . This sketch is from the ship's logbook (http://oldweather. s3.amazonaws.com/ow3/final/USS\%20 Thetis/vol610/vol610_040_1.jpg).
Figure 23. Sketch map of the Bogoslof Island area July 29, 1906, by Robert Dunn (Dunn, 1908). Grewingk Id. is the same as New Bogoslof, and Joanna Bogoslova Id. is the same as Old Bogoslof in previous figures. Dunn reported warm water (approximately $92^{\circ} \mathrm{F}$ ) in the lagoon surrounding the new island.
On July 29, 1906, Mr. Robert Dunn, aboard the schooner Bear, reached Bogoslof Island. Dunn described the new third island situated between Old and New Bogoslof (fig. 23; Dunn, 1908). Dunn reports that this new island was observed by local inhabitants as early as the winter of 1904-05, although this report was contradicted by a local hunter who was in the vicinity of Bogoslof Island in spring 1905 and saw nothing unusual and no third island (Dunn, 1908). According to Dunn, in late March 1906, Mr. Ed Lee, the Captain of the schooner Bear, observed "violent and persistent" snow squalls in the vicinity of Bogoslof Island that appeared unusual to him given the clear weather in the region (Dunn, 1908). Hunters on the north side of Umnak Island also reported seeing dense steam emissions at Bogoslof in late March 1906. On April 20, 1906, the schooner Bear passed by Bogoslof Island and those onboard reported seeing steam emissions but no new island (Dunn, 1908). Dunn reached the new volcanic island on July 29, 1906, and climbed to the top of the cooling lava, which he remarked "was as stable as chocolate fudge." Dunn estimated that the lava dome was about $400 \mathrm{ft}$ high and had the profile of "the beak of a parrot with head in air" (fig. 24). He described a spire within the lava dome as "almost sheer, and smooth as a billiard ball, as if tempered and polished in its hot excursion up from Hades" (fig. 25). Dunn described the volcanic island as a whole as "a pudding of slag fresh from that great furnace of the unknown."

Information from the logbook of the U.S. Revenue steamer Perry on July 29, 1906, indicated that the new island had "ceased smoking" but a "small spot of fire" was visible on the "near side." Lieutenant William T. Stromberg of the steamer Perry produced a sketch map of the area (fig. 26; reproduced in Jaggar, 1908a) that corroborates the observations made by Dunn (1908). A September 1906 photograph by H.G. Ebert of the steamer Perry shows steam rising from Metcalf Cone (fig. 27).

According to Jaggar (1908b), an Unalaska area sea captain, Henry Dirks, observed a fourth new island in the Bogoslof area in the spring of 1907 that rose adjacent to Metcalf Cone. Munger (1909) reports that this island was nested against Metcalf Cone, forming a single island (fig. 28) and 


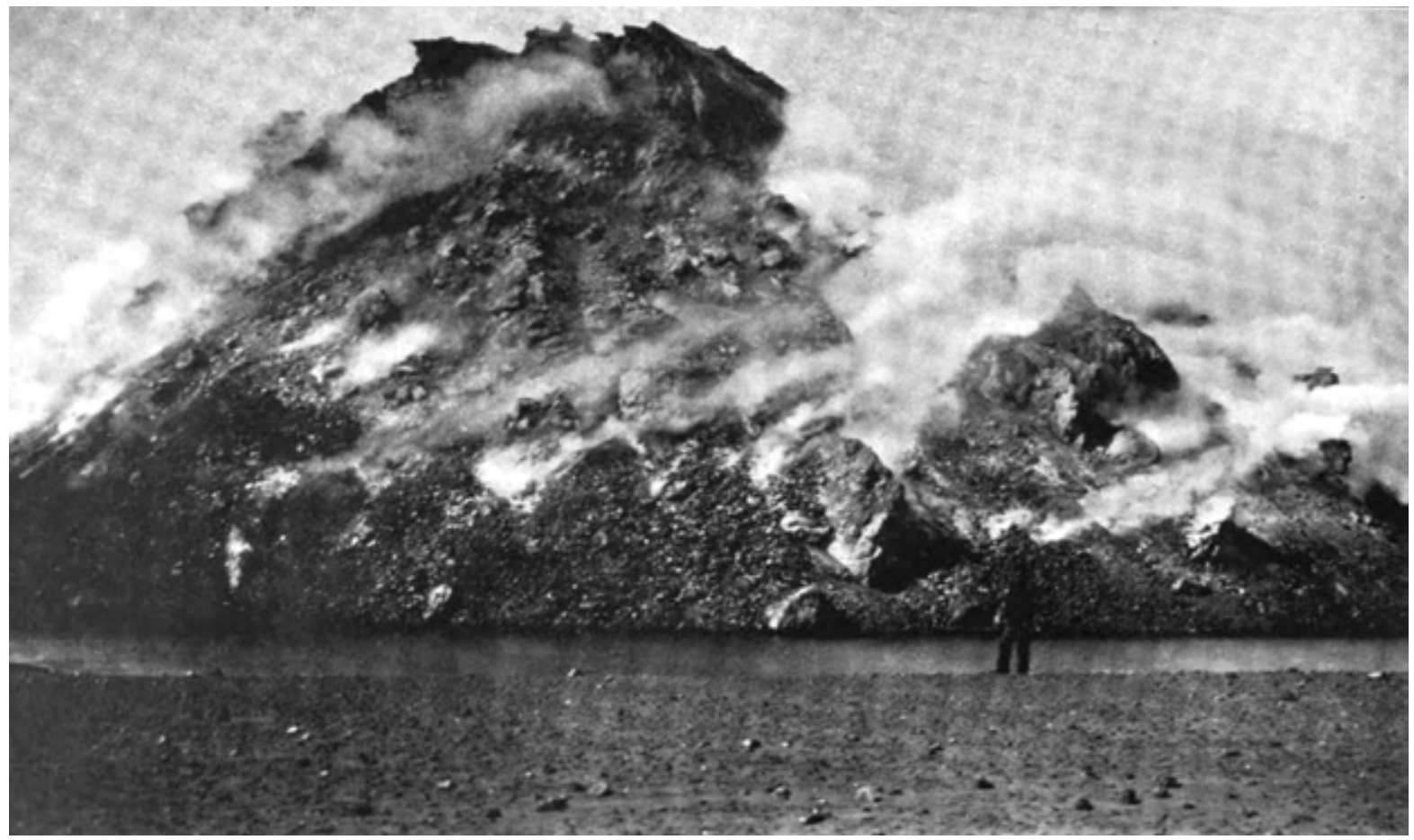

Figure 24. Photograph of 1906 lava dome. Estimated height of the lava dome was about 400 feet (Dunn, 1908). Photograph by Robert Dunn, July 29, 1906.

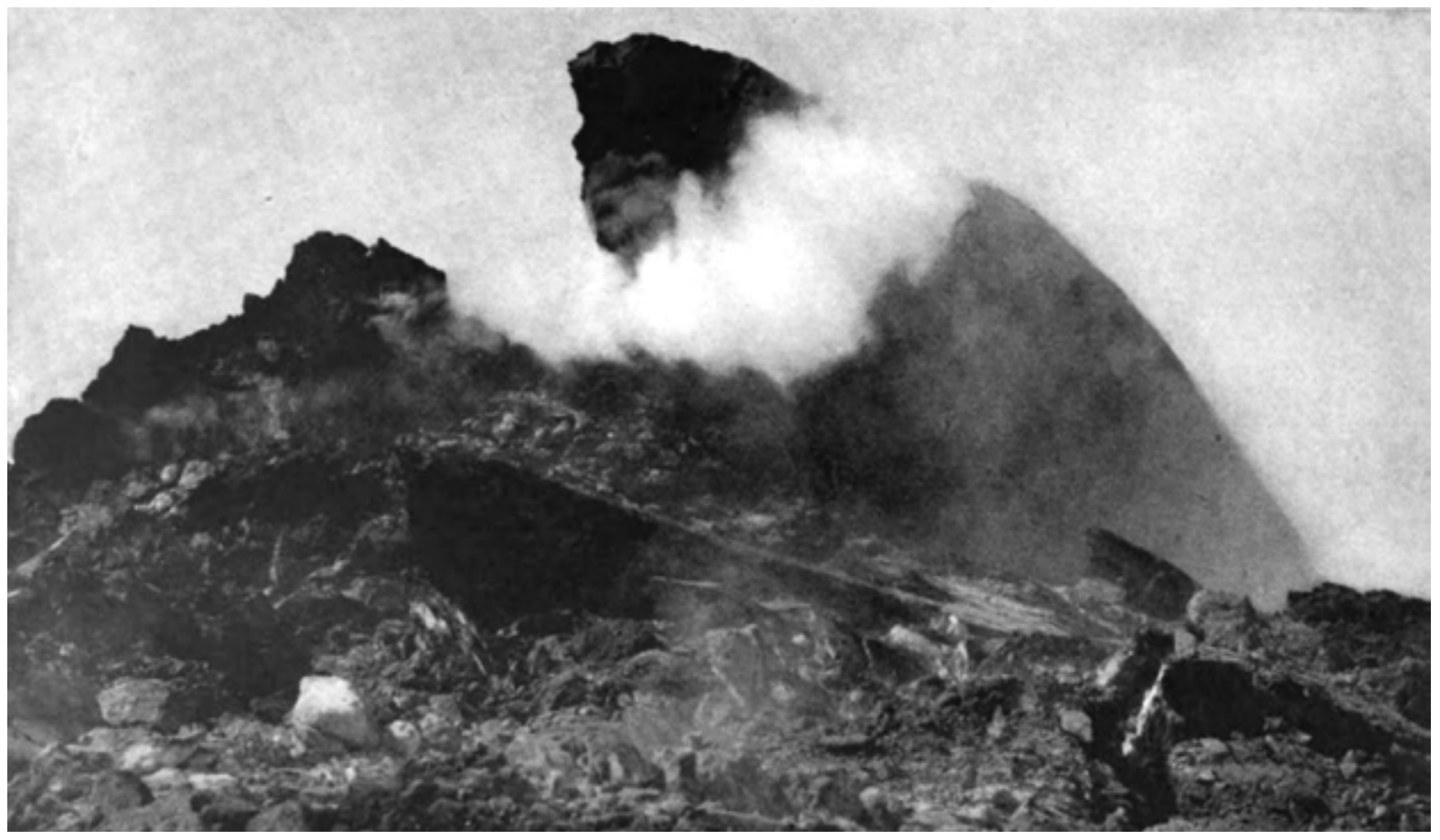

Figure 25. Photograph of upper part of 1906 lava dome. Estimated length of the whaleback spire was about 40 feet from base to top (Dunn, 1908). Photograph by Robert Dunn, July 29, 1906. 


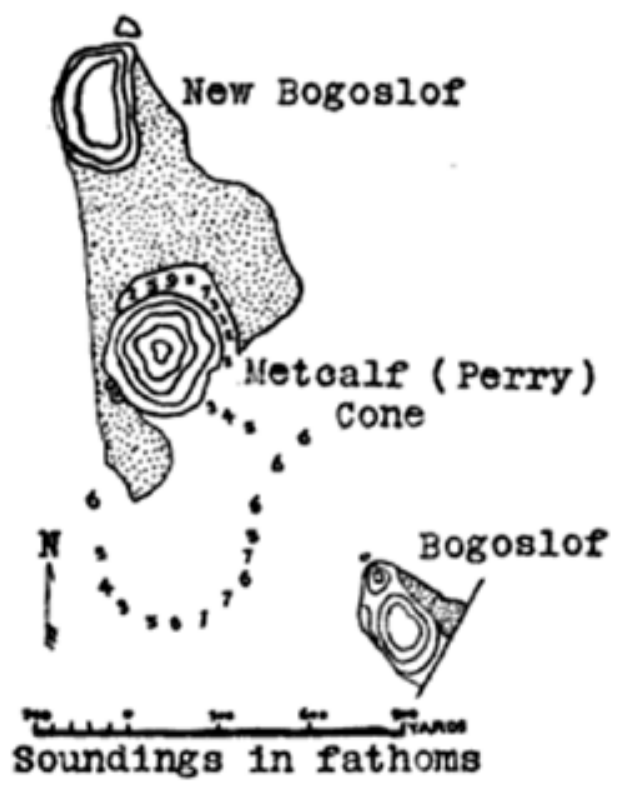

Figure 26. Map of Bogoslof Island, July 1906. Map by Lieutenant W.T. Stromberg (Jaggar, 1908a). may have developed over the winter of 1906-07, but does not cite a source for this assertion. In July 1907 the Revenue cutter McCulloch visited the Bogoslof area and observers onboard confirmed that a new volcanic island had developed, but that about half of Metcalf Cone was gone with the steaming "McCulloch Peak" in its place (Jaggar, 1908b). Jaggar (1908b) remarks that a "violent explosion broke Metcalf Cone in twain" and suggests that "the marks of flood waves and bombs and pumice" on Old Bogoslof are evidence of explosive destruction of Metcalf Cone.

Thomas A. Jaggar visited Bogoslof on August 7, 1907, and provided observations, photographs, and a sketch map of the volcanic islands (figs. 29-32). He estimated that about $25 \mathrm{ft}$ of uplift of Old Bogoslof had occurred between 1906 and the time of his visit in August 1907 based on the difference in the position of features recognizable in 1906 photographs and his observations in 1907 (Jaggar, 1908b). Jaggar estimated the summit of McCulloch Peak to be about $450 \mathrm{ft}$ above sea level and the diameter of the nearly circular lava dome at about 2,000 ft. McCulloch Peak was partly surrounded by a salt-water lagoon with a temperature of $90^{\circ} \mathrm{F}$ (Jaggar, 1908b).

Arthur S. Eakle also visited Bogoslof Island on August 7, 1907, and described Castle Rock (Old Bogoslof) as being "cold" and observed no evidence of "fire" or steam at Fire Island (New Bogoslof) (Eakle, 1908). According to Eakle, both Metcalf and McCulloch peaks were hot and actively steaming and the lagoon surrounding McCulloch peak was boiling. Eakle described Metcalf and McCulloch domes as being composed of hornblende andesite, basalt, basaltic agglomerate, and pumice (Eakle, 1908).

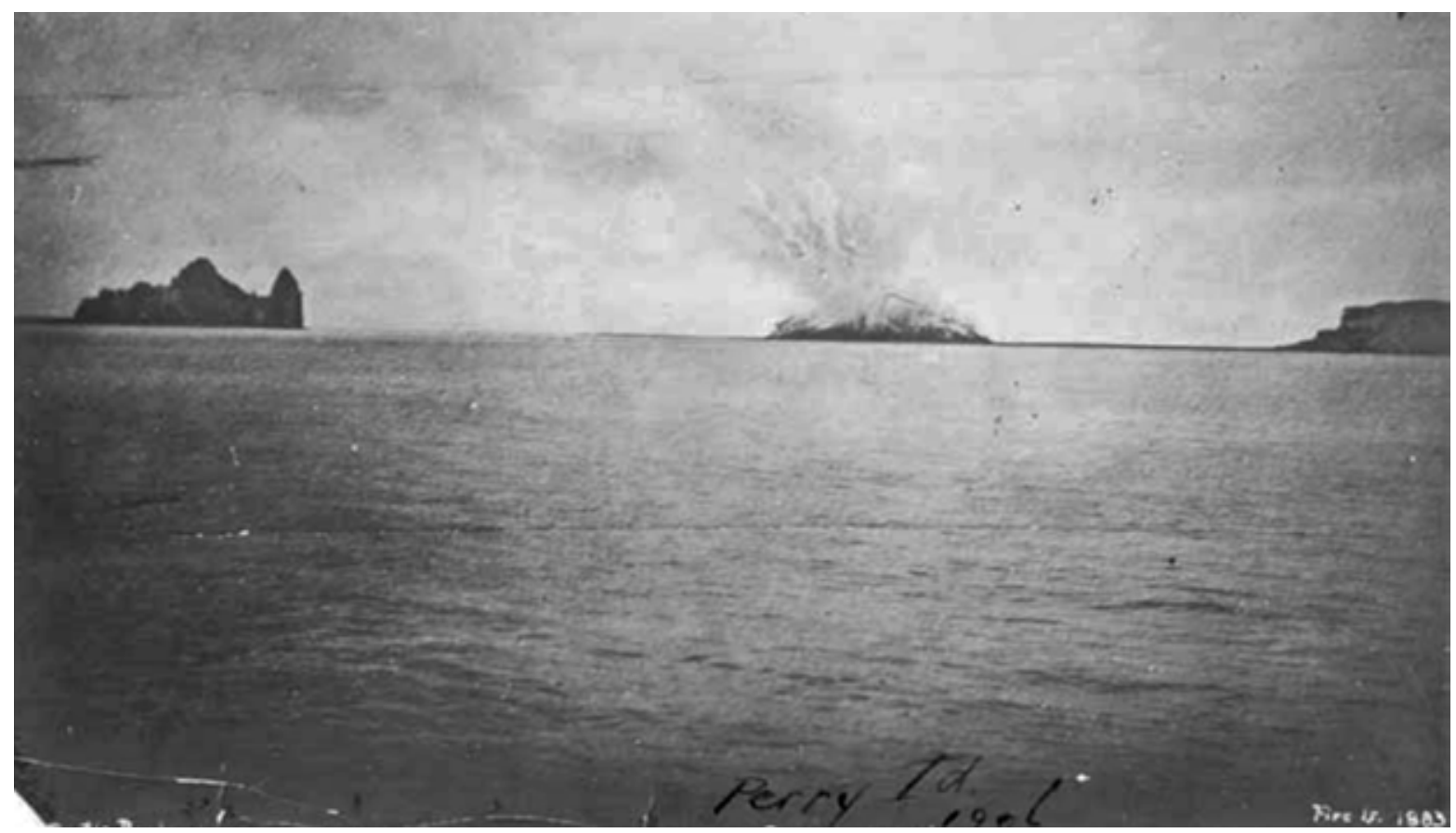

Figure 27. Photograph of Old Bogoslof (also known as Castle Rock) on left, Metcalf Cone (also known as Perry Island or Perry Peak) in middle, and New Bogoslof (also known as Grewingk or Fire Island) on right taken September 1906. Photograph by H.G. Ebert, surgeon aboard the Revenue steamer Perry. 
A

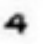

3
1

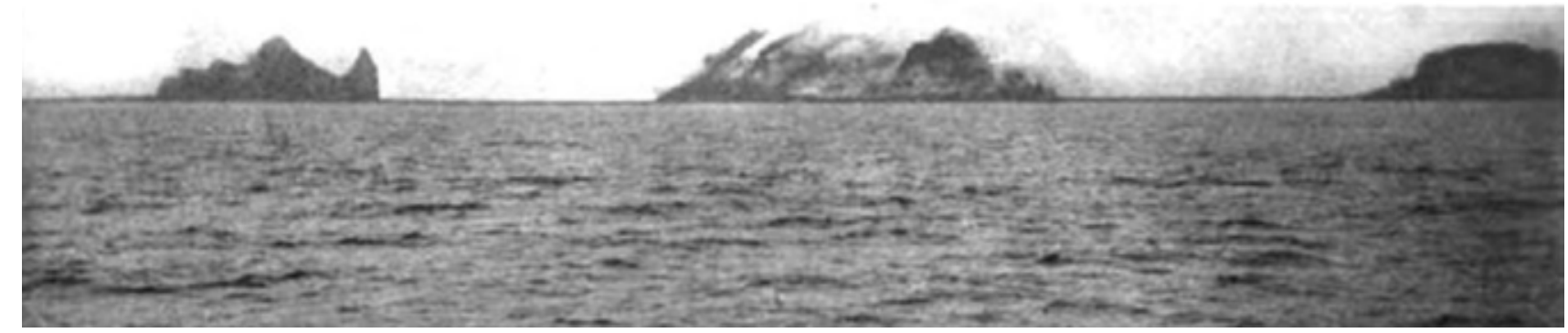

Figure 28. Photograph of the Bogoslof area taken July 4, 1907. Feature labelled 1 is New Bogoslof (also known as Fire Island and Grewingk), 2 is Metcalf Cone (also known as Perry Peak or Perry Cone), 3 is McCulloch Peak, and 4 is Old Bogoslof (also known as Castle Island or Castle Rock). View is toward the west. Photograph by Captain F.M. Munger.

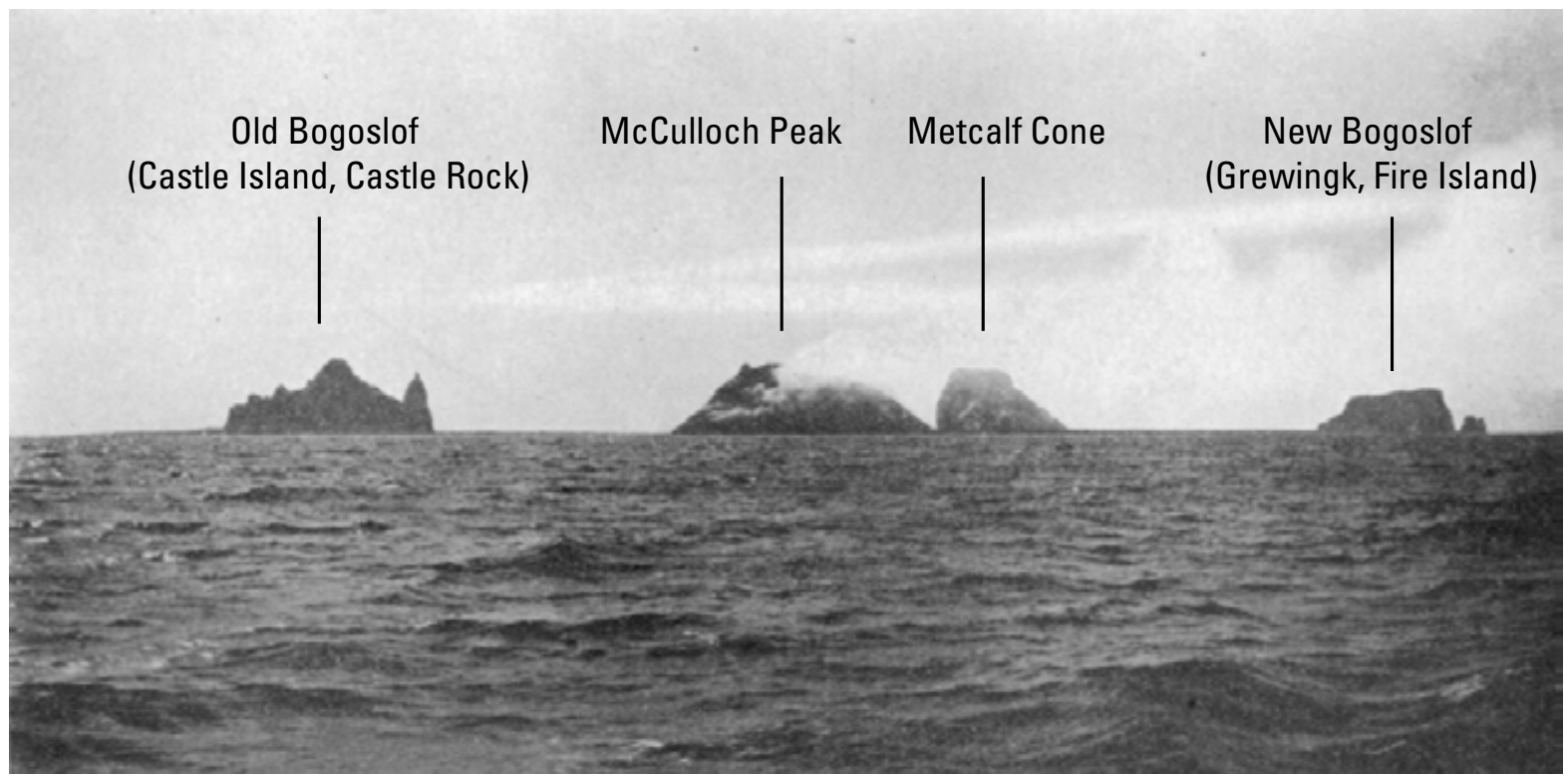

Figure 29. Photograph of the Bogoslof area taken August 7, 1907, showing four lava accumulations and the names used in various publications describing them. Old Bogoslof formed between 1796 and 1804, McCulloch Peak formed in 1907, Metcalf Cone formed in 1906, and New Bogoslof formed in 1883. View is toward the west From Jaggar (1908b).

On September 1, 1907, at about 5 p.m. local time, a dark black cloud was observed passing over Unalaska Island (Eakle, 1908; Munger, 1909). Sandy ash fall, 0.187-0.25 inches $(\sim 5-6 \mathrm{~mm})$ thick was reported at the village of Iliuliuk, near present day Unalaska (Eakle, 1908; Jaggar, 1908b; Munger, 1909). Eakle (1908) described the ash from the September 1,1907 , eruption as "gray pumiceous ash, containing occasional hornblende crystals" and presumably "finely shattered hornblende andesite." The Revenue cutter McCulloch reached Bogoslof on October 15, 1907, and observers on board reported that McCulloch Peak had been destroyed (fig. 33; Munger, 1909). A portion of Metcalf Cone remained and "was standing in grim silence as a headstone at the grave of the departed peak" (Jaggar, 1908b). The profile of the island in
October 1907 from Metcalf Cone to New Bogoslof appeared smoothed over by the accumulation of pyroclastic debris (Jaggar, 1908b). Jaggar (1908b) reports that a deep bay occupied the former site of McCulloch Peak and in October 1907 steam was rising "in considerable quantities from the surface of the water." It is likely that the main phase of the eruption that destroyed McCulloch Peak occurred on or around September 1, 1907, producing the ash cloud observed on Unalaska Island. There were no other reports of ash clouds during that period.

The Revenue cutter Rush visited the Bogoslof area in July 1908 and officers on board observed that the remnant of Metcalf Cone was no longer present (fig. 34), having been destroyed by eruptive activity sometime between October 15, 1907, and July 1908 (Munger, 1909). Jaggar (1908b) 


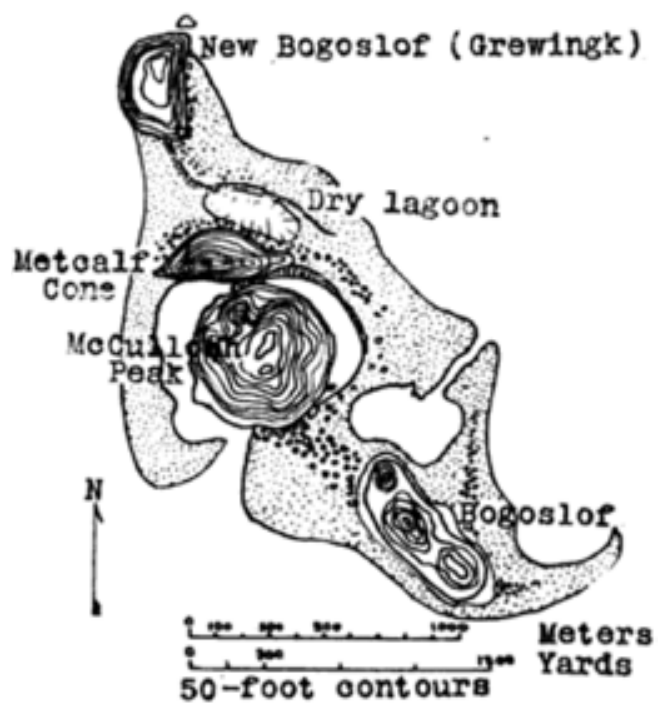

Figure 30. A 1907 map of the Bogoslof area showing the four main volcanic vents at the time. From Jaggar (1908b). speculates that a new cone may have developed over the winter of 1907-08 and then was explosively destroyed possibly before June 1908. However, there are no corroborating reports of activity or ash emission and thus the mechanism and timing of the destruction of what remained of Metcalf Cone is not known. During the July 1908 visit to Bogoslof (Munger, 1909), observers on board the Rush noted that a high ridge of land, as high as $300 \mathrm{ft}(90 \mathrm{~m})$ above sea level, extended from Fire Island (New Bogoslof or Grewingk) to Castle Rock (Old Bogoslof) (fig. 34). A September 1908 map, made by Lieutenant Bernard Camden on board the Revenue cutter $\mathrm{McCulloch}$, shows a large embayment open to the southwest, about $1 \mathrm{mi}$ $(1.6 \mathrm{~km})$ wide and as much as 25 fathoms (45 m) deep, in the middle part of the island (fig. 35). The ridge connecting New Bogoslof and Old Bogoslof was likely a tuff ring and the embayment was likely the vent area for the eruption that destroyed the remaining part of Metcalf Cone. During the September 1908 visit observers reported that the southwestern part of the island was smoking (steaming?) and patches of discolored water were present on the north-northwest sides of the island, probably a result of wave erosion of pyroclastic deposits.

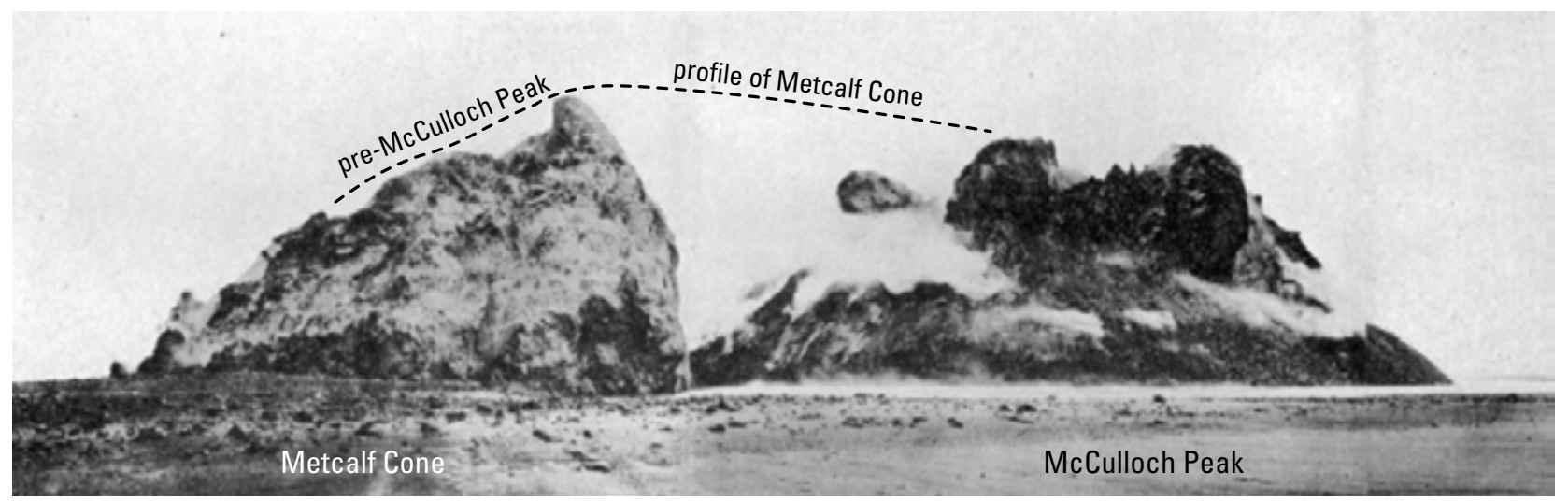

Figure 31. Photograph of partly destroyed Metcalf Cone and McCulloch Peak, August 7, 1907. View is to the southeast. From Jaggar (1908b).

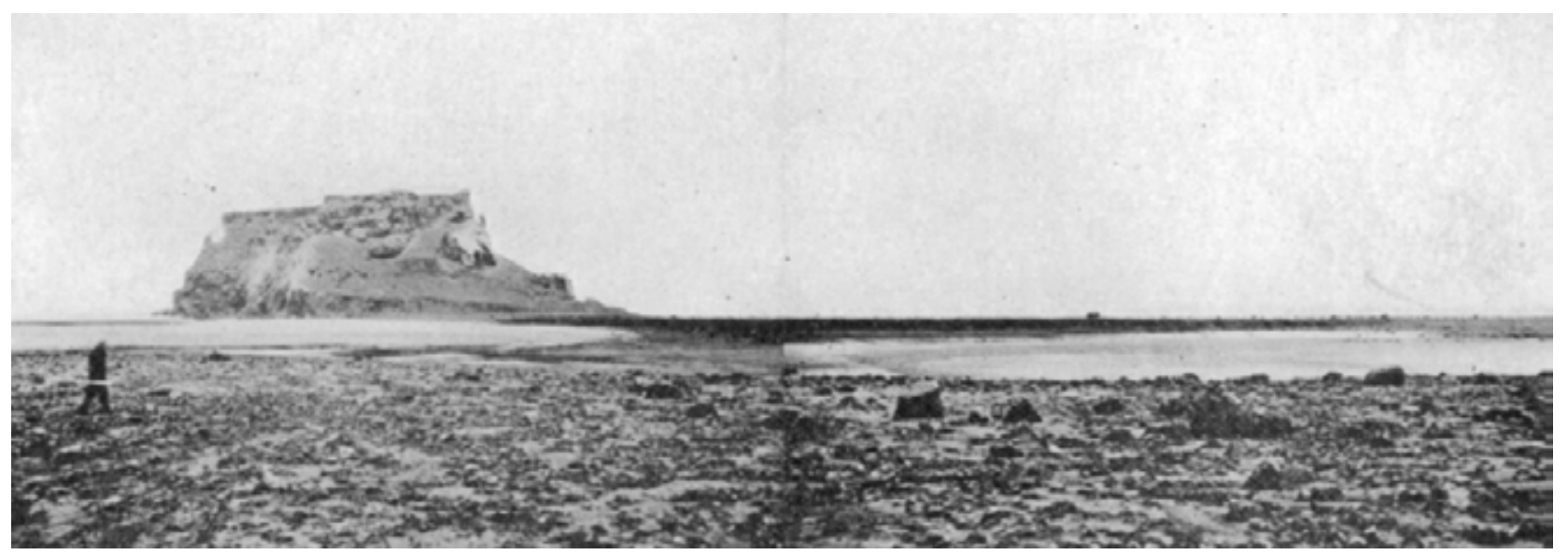

Figure 32. Photograph of New Bogoslof Island, August 7, 1907. Note the flat, gradually sloping surface of New Bogoslof. This is unusual relative to the more dome-shaped appearance of the other lava accumulations at Bogoslof. It is unclear why the summit of New Bogoslof in this photograph has a flat surface. It is possible that deflation of the Bogoslof edifice allowed for wave erosion of the top of New Bogoslof and later inflation brought the feature to its 1907 position. This would require 30 meters or more of vertical motion of the Bogoslof edifice which may be implausible. From Jaggar (1908b). 


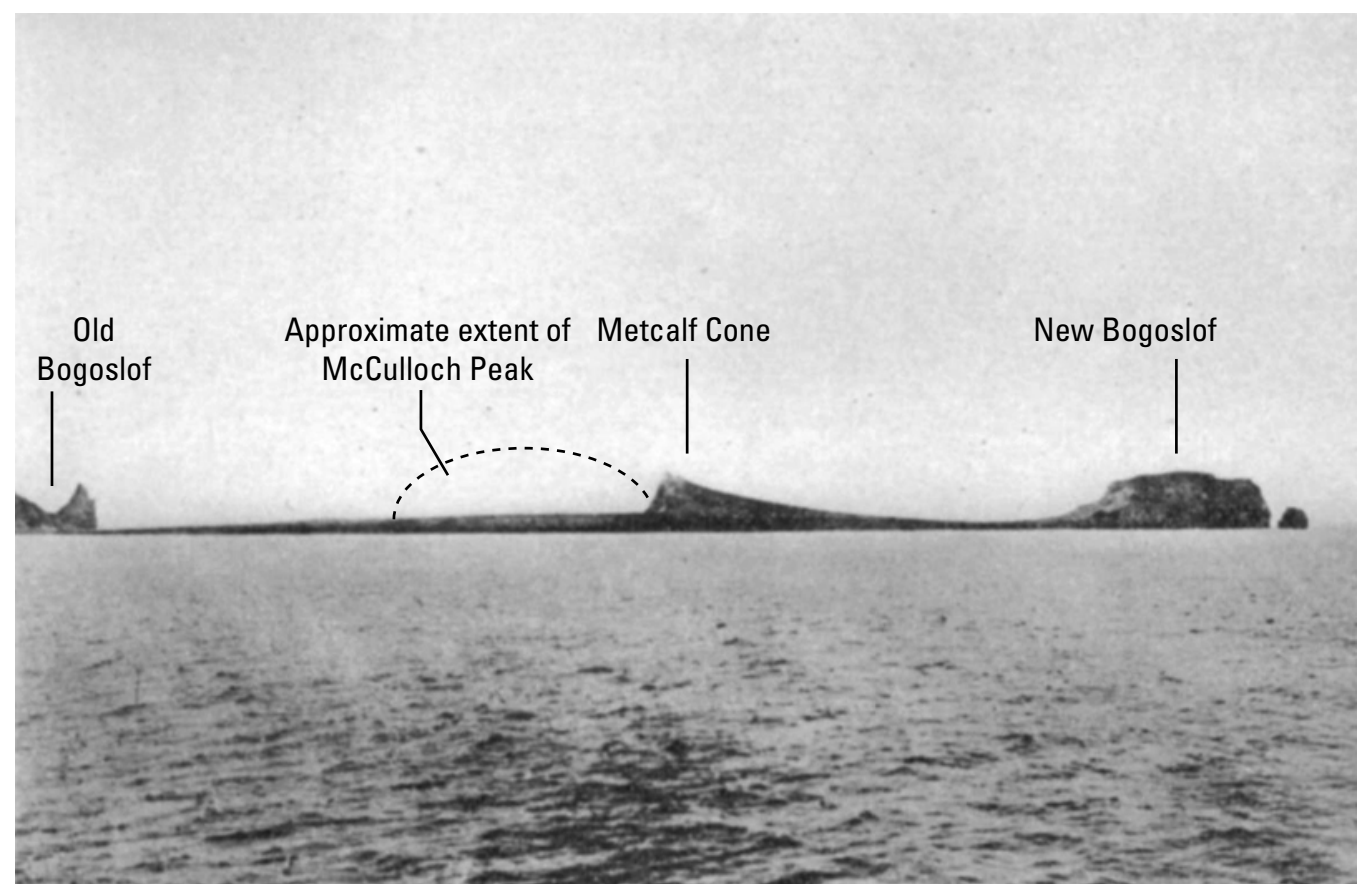

Figure 33. Photograph of New Bogoslof, Metcalf Cone, and Old Bogoslof, October 15,1907 . View is toward the southwest. Eruptive activity on or around September 1, 1907, destroyed McCulloch Peak and part of the remaining Metcalf Cone. Photograph by F.M. Munger.

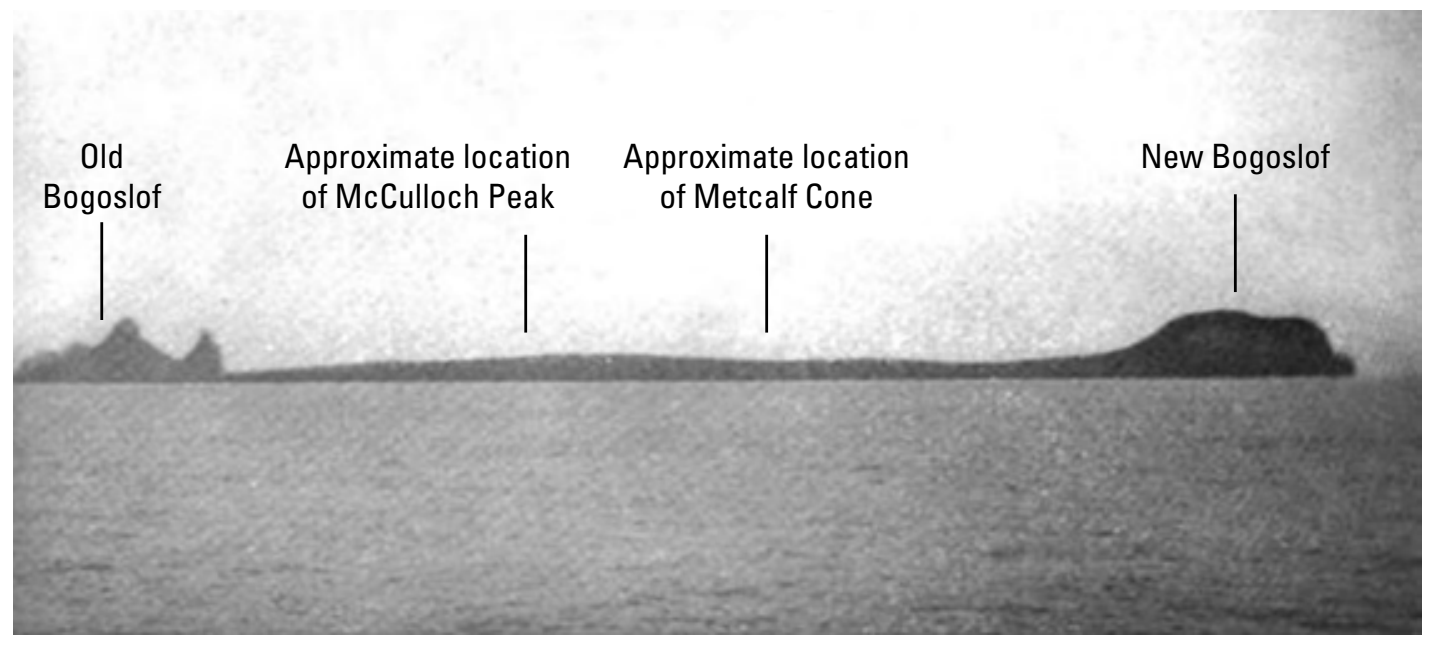

Figure 34. Photograph of Bogoslof Island taken July 1908 showing Old and New Bogoslof and the approximate locations of Metcalf Cone and McCulloch Peak, both of which were removed by explosive eruptive activity September 1907-July 1908. The land area between New and Old Bogoslof is probably pyroclastic debris generated by the eruptions that destroyed McCulloch Peak and Metcalf Cone. Photograph by F.M. Munger.

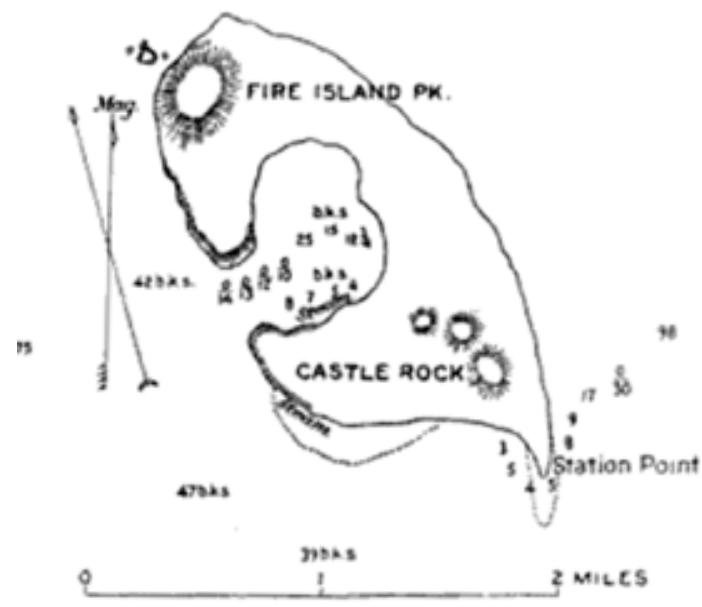

Figure 35. July 1908 map of Bogoslof Island, made by Lieutenant Bernard H. Camden of the Revenue cutter Rush. The large circular embayment in the center of the island that opens to the southwest was the approximate location of Metcalf Cone and McCulloch Peak. Fire Island Peak is also known as New Bogoslof and Grewingk. Castle Rock is also known as Old Bogoslof. From Munger (1909). 
Additional unrest at Bogoslof in 1908 is described in a report by Prosser (1911) and a generalized article by Hunnicutt (1943). Hunnicutt (1943) mentions that the steamer Albatross was in the Bogoslof area in 1908 and crewmembers observed multiple dome-like rises of the ocean surface, like "a colossal soap bubble," associated with gas emissions and "gigantic clouds of smoke and steam." Based on this report, it is unclear if the crew of the Albatross observed an actual eruption, or witnessed upwelling of hot water and steam emissions. The source of this information was not given, but a report by Prosser (1911) is the likely source. Prosser (1911) describes a visit to Bogoslof on July 7, 1908, by the Albatross with observations by crew members of "a gigantic dome-like swelling" of the water, "as large as the dome of the capital at Washington" that subsided and rose again. Each episode of subsidence was preceded by a noticeable emission of gas "like a huge bubble pushing its way through the water" (Prosser, 1911). This was followed by the emission of "great clouds of smoke and steam" significant enough to frighten the observers on the Albatross. In addition to these emissions, the crew of the Albatross described "fire, smoke, and white hot lava" that streamed from a sea level volcanic crater (Prosser, 1911). According to the officers of the Albatross, the volcanic cloud generated on July 7 reached a diameter of $3 \mathrm{mi}(4.8 \mathrm{~km})$.
Sometime after the visit to Bogoslof by the Albatross (but prior to the arrival of the cutter Tahoma in September 1910), the Revenue cutter Perry reached the area and observers on board saw that a new peak had developed in about the same location as Metcalf Cone (Prosser, 1911). Officers and crew members of the Perry went ashore but reported that the heat from this new cone was so intense that they could only remain on the island a short time (Prosser, 1911).

\section{9-10 Eruptive Activity}

By September 1909 the open embayment observed in 1908 (fig. 35) had been closed off, forming a lagoon (Powers, 1916), probably as a result of wave erosion of the tuff ring that connected Old and New Bogoslof. In addition, two small "islands" were present in the lagoon as of September 1909, one of which was steaming (Powers, 1916). Observations made on June 16, 1910, indicate that the two islands in the lagoon continued to grow and eventually merged to form a single lava dome that stood about $178 \mathrm{ft}(54 \mathrm{~m})$ above sea level (Powers, 1916).

The U.S. Revenue cutter Tahoma reached Bogoslof Island on September 10, 1910, and the volcano appeared

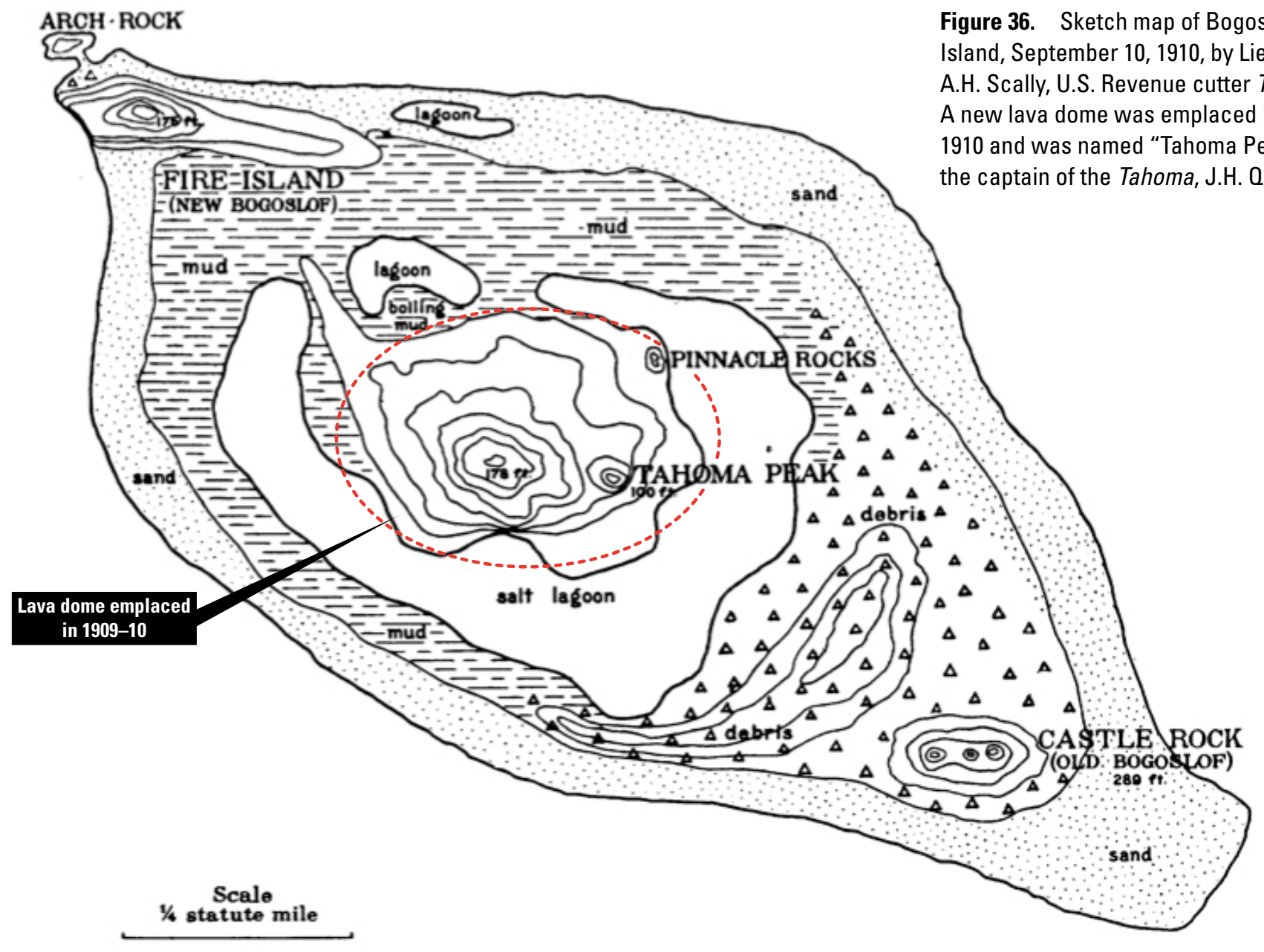


restless but was not erupting (Powers, 1916). The new lava dome that was first observed in the lagoon in September 1909 was named Tahoma Peak by Johnstone H. Quinan, the Captain of the Tahoma, and is shown on figure 36. At the time of the September 10 visit by the Tahoma, steaming was observed at Tahoma Peak and from the surface of the saltwater lagoon surrounding the peak (fig. 36). Geysering, boiling mud, and shallow explosion pits were also observed in the tephra ring deposits around Tahoma Peak (Powers, 1916). Small conical domelets eventually rose into the explosion pits on the northeast side of Tahoma Peak (Powers, 1916).

A landing party from the Tahoma observed a crater, "fifteen hundred feet in diameter, seething with lava, fire, boiling water and steam" (Prosser, 1911). The crater was described as "a huge colander with streams of boiling water spurting upward through the holes and a geyser in the center" (Prosser, 1911).

As the Tahoma again approached Bogoslof on September 18,1910 , the volcano was in a state of vigorous eruption (fig. 37) characterized by at least 3 hours of robust ash emission, lava fountaining and incandescence, several distinct periods of lightning, and base surges (Powers, 1916). The eruption is reported to have taken place from a crater at the summit of Tahoma Peak (Powers, 1916). Lieutenant F.E. Baggar on the Tahoma reported feeling "oppressive heat" when the ship was $6 \mathrm{mi}(9.6 \mathrm{~km})$ from the eruption site. Baggar also described "a column of red hot glowing lava" rising as high as a half mile $(800 \mathrm{~m})$ above sea level and "streams of living fire rose and fell in a pyrotechnic shower" (Prosser, 1911). The eruptive activity was accompanied by a nearly constant roar and thunder-like sounds issuing from the crater (Prosser, 1911).

\section{1-26 Observations}

Observations of Bogoslof during the period from 1911 to 1926 are limited. Powers (1916) gives an unreferenced report of steam and smoke issuing from the crater of Tahoma Peak in July 1913. Arthur A. Nordhoff, a passenger on the steamship Victoria, passed by Bogoslof Island on July 20, 1913, and his diary entry for that day describes it as "steaming and smoking and nothing but a small rock island" (https://ncatablog.wordpress.com/1913/07/20/20-july-1913-bogoslof-island-dutchharbor-unalaska/).

Captain James B. Miller, in command of the Coast and Geodetic Survey steamer Patterson, passed by Bogoslof in September 1914 and reported no signs of unrest or activity (Powers, 1916). The U.S. Coast Guard cutter Bothwell visited Bogoslof Island in 1920 and observers reported that there were two small islands with a shallow passage in between, but no evidence of recent eruptive activity (Morris, 1936).

On September 11, 1922, the Coast Guard cutter Algonquin visited Bogoslof Island and the commanding officer, William T. Stromberg, reported that the top of Old Bogoslof was

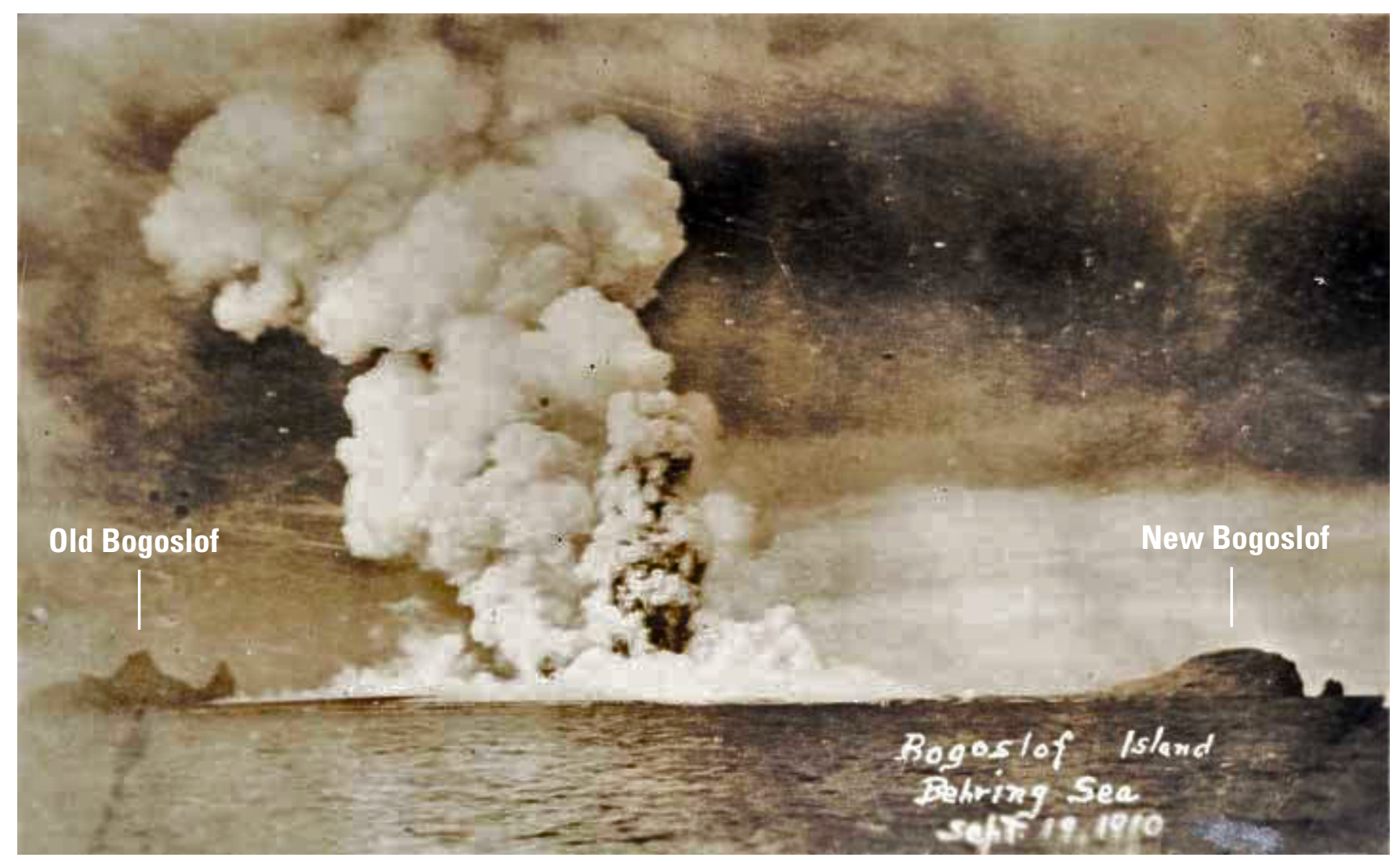

Figure 37. Photograph of Bogoslof volcano erupting September 19, 1910. Photograph taken by Lieutenant F.E. Baggar during a visit to the area by the U.S. Revenue cutter Tahoma. 
$400 \mathrm{ft}$ above sea level and was surrounded by a plateau that he thought was an uplifted part of the sea floor (Morris, 1936). Stromberg also reported that all of the "rocks" on the island appeared cold and there was no sign of volcanic activity.

On July 30, 1923, the Coast Guard cutter Haida reached Bogoslof Island and reported no evidence of volcanic activity. A similar report was provided by crew members of the Coast Guard cutter Unalga when it approached Bogoslof on May 31, 1926.

\section{Eruptive Activity}

On July 24, 1926, the Coast Guard cutter Haida again reached Bogoslof and the commanding officer, W.H. Shea, reported that the open passage between Old Bogoslof and New Bogoslof was now closed off by a low spit (Morris, 1936). Captain Shea also commented that significant volumes of steam were observed issuing from an area at the base of a cliff on the northeast side of Old Bogoslof. No other eruptive activity was noted by observers on the Haida.

Seemingly at odds with these observations are reports of eruptive activity and explosions on July 17 made by local inhabitants (Jaggar, 1930) just seven days before the Coast Guard cutter Haida approached Bogoslof. Jaggar (1930) reports that on July 17 a local whaler observed an explosive eruption and explosions were observed by people on islands near Bogoslof. On August 12, a local whaler reported "black smoke," muddy water near the volcano, and thunder and lightning followed by the emission of a white steam cloud and "fire" at the volcano (Jaggar, 1930). Jaggar (1930) also reports that an explosion occurred in December 1926 and speculates that a lava dome formed subsequent to the explosion.

Byers (1959) reports that submarine explosions occurred between Castle Rock and Fire Island during the summer and fall of 1926 and that a lava dome rose above sea level during the winter of 1926-27. Byers also comments that a ring of explosion debris, about $10 \mathrm{ft}(3.1 \mathrm{~m})$ high, surrounded the dome and connected Fire Island with Castle Rock.

\section{Observations}

Thomas Jaggar visited Bogoslof on July 6, 1927 (Jaggar, 1927, 1930). He observed "a pile of steaming lava rising from a warm lagoon" (fig. 38) and commented that "hot lava was slowly heaving itself from the submerged crater above the seawater" (Jaggar, 1927). Although Jaggar does not give a specific location for the dome he observed, he does relate it to activity observed in 1926 (Jaggar, 1930), so presumably the 1926 and 1927 lava domes are the same feature. According to Jaggar (1930), by July 6, 1927, the lava dome was about $200 \mathrm{ft}$ $(60 \mathrm{~m})$ high and about $1,000 \mathrm{ft}(300 \mathrm{~m})$ across. Jaggar speculated that the lava dome was in the final stages of effusion having been mostly emplaced a short time prior to his 1927 visit (Jaggar, 1930). He also described Bogoslof Island as consisting of the lava dome situated in the "midst of sand banks" and that the dome and the sand banks formed a single island with a "complete ring-shaped salt water lagoon, surrounded in turn by a complete ring of sand permitting no connection with the sea except by seepage" (Jaggar, 1930). Ballistic impact craters containing ' $a$ 'a bombs and "blocks of pumice one to two feet in diameter" were also described during his 1927 visit (Jaggar, 1927, 1930).

Observations of Bogoslof made in late 1927 or early 1928, that were reported in the Coast and Geodetic Survey Letter (Letter 12, for 1928, Daily Memorandum from H.O. dated January 3, 1928; Morris, 1936), indicated that the volcano was in some state of eruption ("great activity") and that a new "mound" had been extruded in about the location of Metcalf Cone and McCulloch Peak (fig. 38) and was steaming profusely. Castle Rock and Fire Island were also observed to be connected by a sand spit (Morris, 1936).

\section{Observations}

Captain Nelson of the Alaska Commercial Company reported that on October 31, 1931, "fire" was observed issuing from Bogoslof Island (Jaggar, 1932). Nelson remarked that the

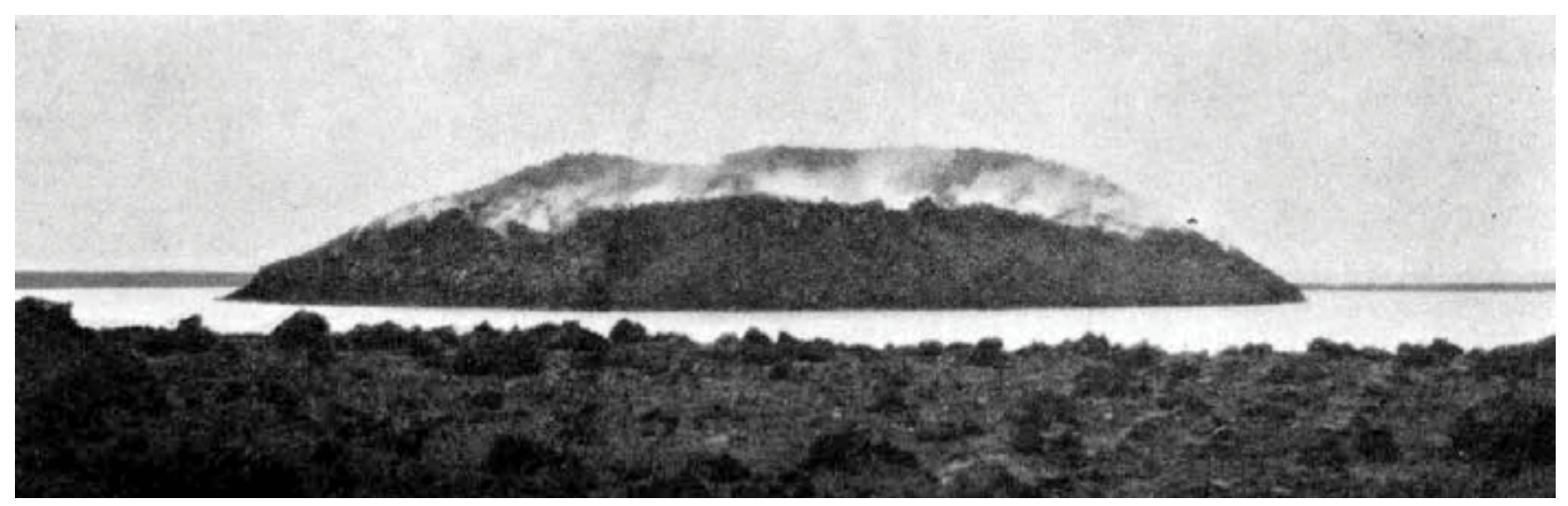

Figure 38. Photograph of steaming lava dome on Bogoslof Island, June 28, 1928, view is toward the southwest. The lava dome is 61 meters (200 feet) high and 305 meters (1,000 feet) wide and the material in the foreground is explosion debris consisting of bombs and blocks (Jaggar, 1930). Photograph by R.A. Wheeler. 
Bogoslof was always "smoking" but observations of fire were unusual.

\section{Observations}

During June-August 1935 a hydrographic survey of Bogoslof Island was completed by the U.S. Coast and Geodetic Survey (Morris, 1936). At that time Bogoslof consisted of a main island that included Castle Rock, a lava platform, and a flat-topped, triangular-shaped accumulation of tephra erupted in 1926-28 (figs. 39, 40). Fire Island was connected to the main island by a shallow rocky bar that was locally exposed during low tide.

\section{Observations}

During the summer of 1947, U.S. Geological Survey geologist F.M. Byers, Jr. made a one-day visit to Bogoslof Island (Byers, 1959). As a result of this visit, Byers produced the first geologic map of Bogoslof (fig. 41) and made a number of important observations. Byers provided petrographic descriptions of the main rock units exposed on Bogoslof Island, including hornblende andesite and vent agglomerate of Castle Rock, hornblende basalt of Fire Island, basaltic ash, agglomerate, and hornblende basalt erupted during the 1926-28 eruptive period (Byers, 1959).

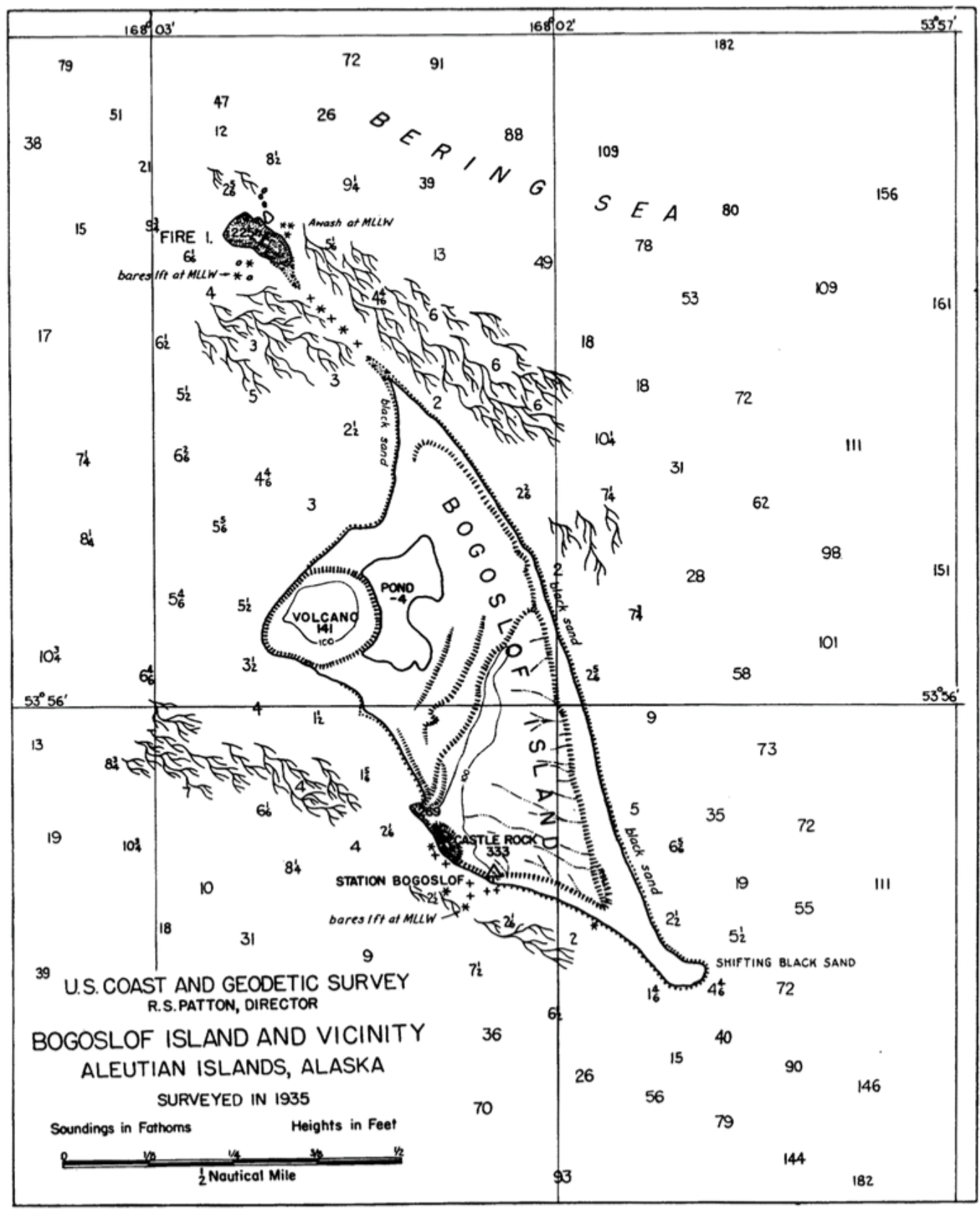

Figure 39. Hydrographic survey chart of Bogoslof Island, 1935. The feature labeled "Volcano 141" is the lava platform erupted during the 1926-28 eruption. From Smith (1937). 


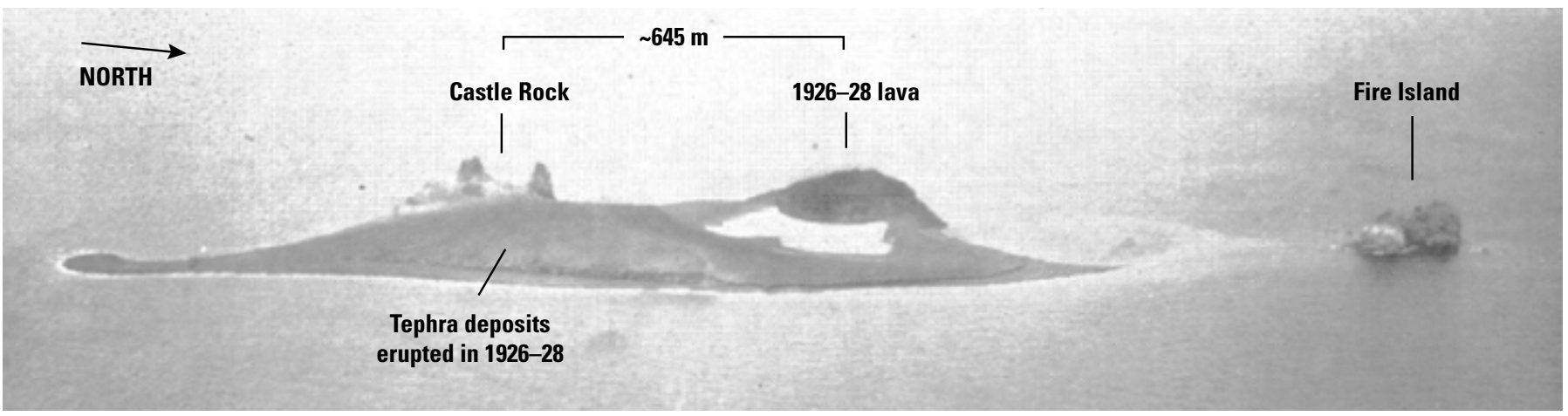

Figure 40. Aerial photograph of Bogoslof Island, 1935. Photograph by U.S. Navy. M, meters.

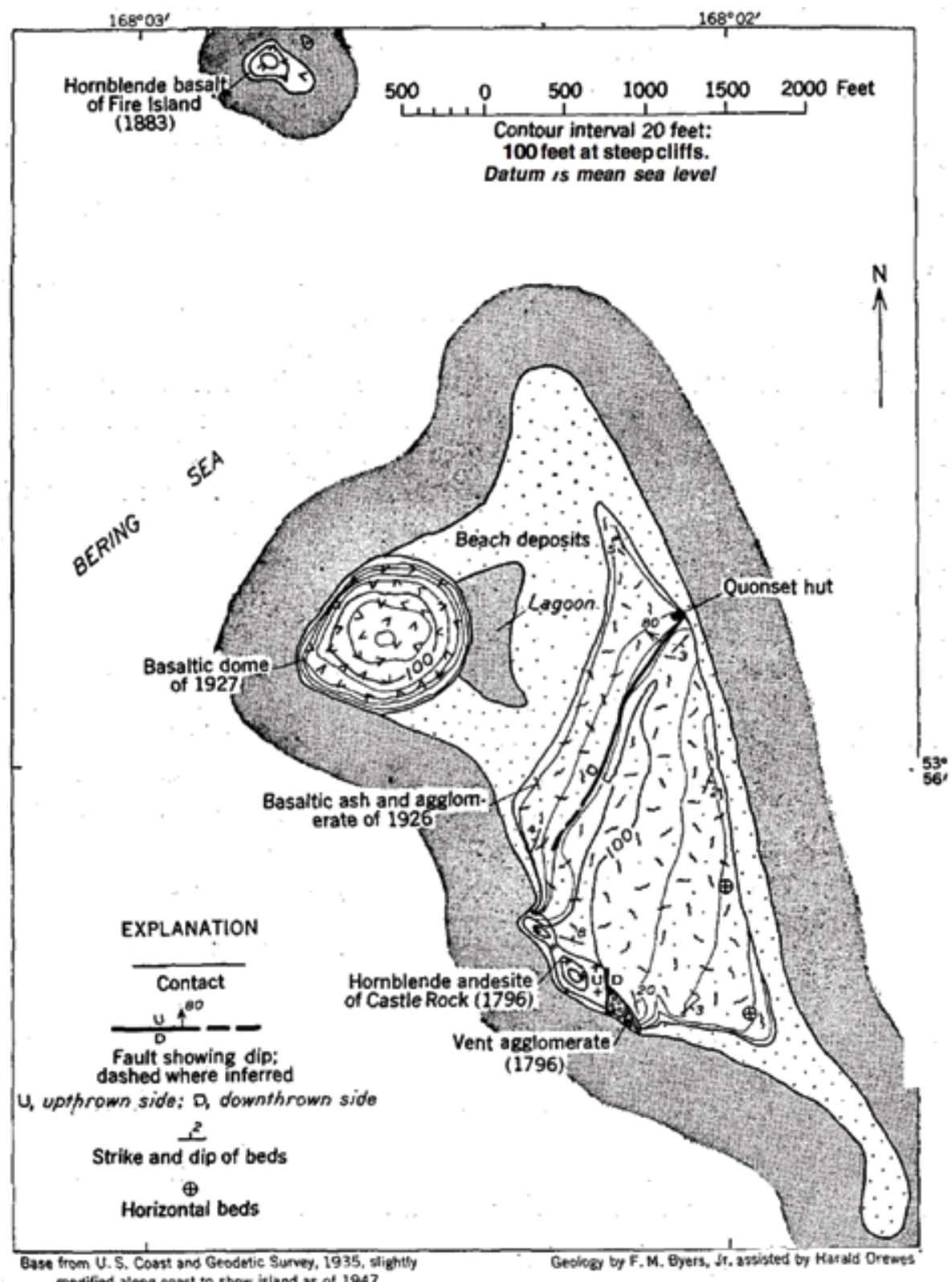

modified along coast to show island as of 1947
Figure 41. Geologic map of Bogoslof Island, 1947. From Byers (1959). 


\section{Eruptive Activity}

After a roughly 64-year period of quiescence, Bogoslof began erupting again in early July 1992. The eruption was first observed in National Oceanic and Atmospheric Administration satellite imagery at about 15:00 Alaska Daylight Time (AKDT) July 6, 1992, and a few hours later was confirmed by pilot reports of a steam and ash cloud over Bogoslof (McGimsey and others, 1995). Intermittent emissions of steam and ash occurred from July 6-13 and was followed by a period of relatively continuous ash emission on July 14 and 15. Steam and ash plumes reaching as high as $18,000 \mathrm{ft}(5.5$ $\mathrm{km})$ above sea level and extending beyond the volcano as far as $62 \mathrm{mi}(100 \mathrm{~km})$ to the southeast were reported during this period. Intermittent activity continued through July 20 and at about 17:00 AKDT on July 20 a vigorous steam and ash emission occurred that produced a volcanic cloud reaching as high as $26,000 \mathrm{ft}(8 \mathrm{~km})$ above sea level (McGimsey and others, 1995).

Observations by local fisherman indicated that a "new island" between Fire Island and Bogoslof Island was present by July 7, 1992 (Global Volcanism Program, 1992). A steaming lava dome was also observed on July 21 and was observed and photographed on July 24 (fig. 42), which was also the last date of any noteworthy emission of steam and ash. An Alaska Volcano Observatory visit to Bogoslof Island in 1994 indicated that the 1992 lava dome was about $900 \mathrm{ft}(275 \mathrm{~m})$ in diameter and $490 \mathrm{ft}(150 \mathrm{~m})$ high (Harbin, 1994). Samples of the lava dome collected in 1994 consist of dark grey to black porphyritic hornblende basaltic andesite (Harbin, 1994).

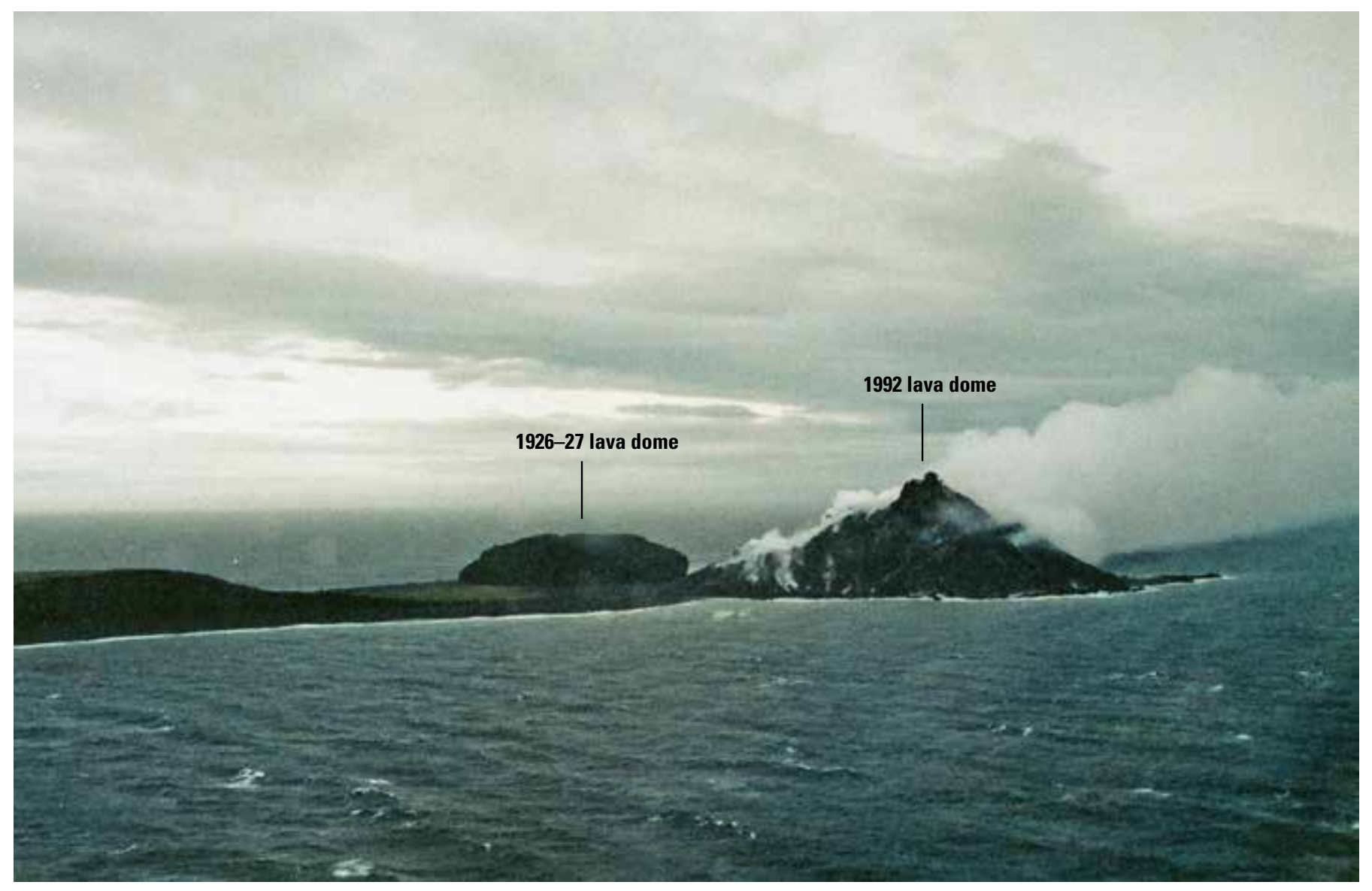

Figure 42. Photograph of the 1992 lava dome, taken July 24, 1992. View is toward the northwest. Photograph by Roy Torres, National Marine Fisheries Service. 


\section{6-17 Eruptive Activity}

After an approximately 24-year period of repose, Bogoslof began erupting sometime between December 12 and 14, 2016. As of late August 2017 there have been at least 64 eruptive episodes detected by some combination of seismicity, infrasound, lightning, and satellite observations. Most of the volcanic clouds generated by explosive eruptive activity have been light colored, suggesting that they are water- and icerich. Maximum cloud heights were 9-14 km above sea level, and trace amounts of ash fall on nearby Unalaska Island have occurred only twice, on January 30-31 and March 8, 2017.

The eruption resulted in some significant changes to the configuration of Bogoslof Island. A broad, low-relief tuff ring developed around the north and east sides of the island and a lava dome was emplaced on the southwest side of the island near Castle Rock (fig. 43). At least two additional subaerial lava domes were produced during the eruption. One was emplaced and destroyed in early June 2017, a second lava dome emerged August 18, 2017, and was destroyed by explosive activity in late August.

\section{Hazards Associated with Bogoslof Eruptions}

The majority of eruptions from Bogoslof volcano have occurred from shallow submarine vents and the resulting eruptive products reflect the complex interactions that can occur between magma, seawater, and water-saturated debris in a shallow submarine setting. Based on the observations of historical eruptions, as well as the information obtained thus far from the 2016-17 eruption, it is possible to describe some of the potential volcanic hazards associated with eruptions of Bogoslof volcano. The most important hazards include volcanic clouds and ash fallout, pyroclastic base surge, ballistic ejecta, mud rain, and floating volcanic debris. Other potential hazards include submarine slope failures and sector collapse of the volcanic edifice, explosively generated water waves, and expulsion of hot water. Although Bogoslof Island is not populated, these hazards may impact aircraft, visitors to Bogoslof, nearby communities of Dutch Harbor/Unalaska, and marine life.
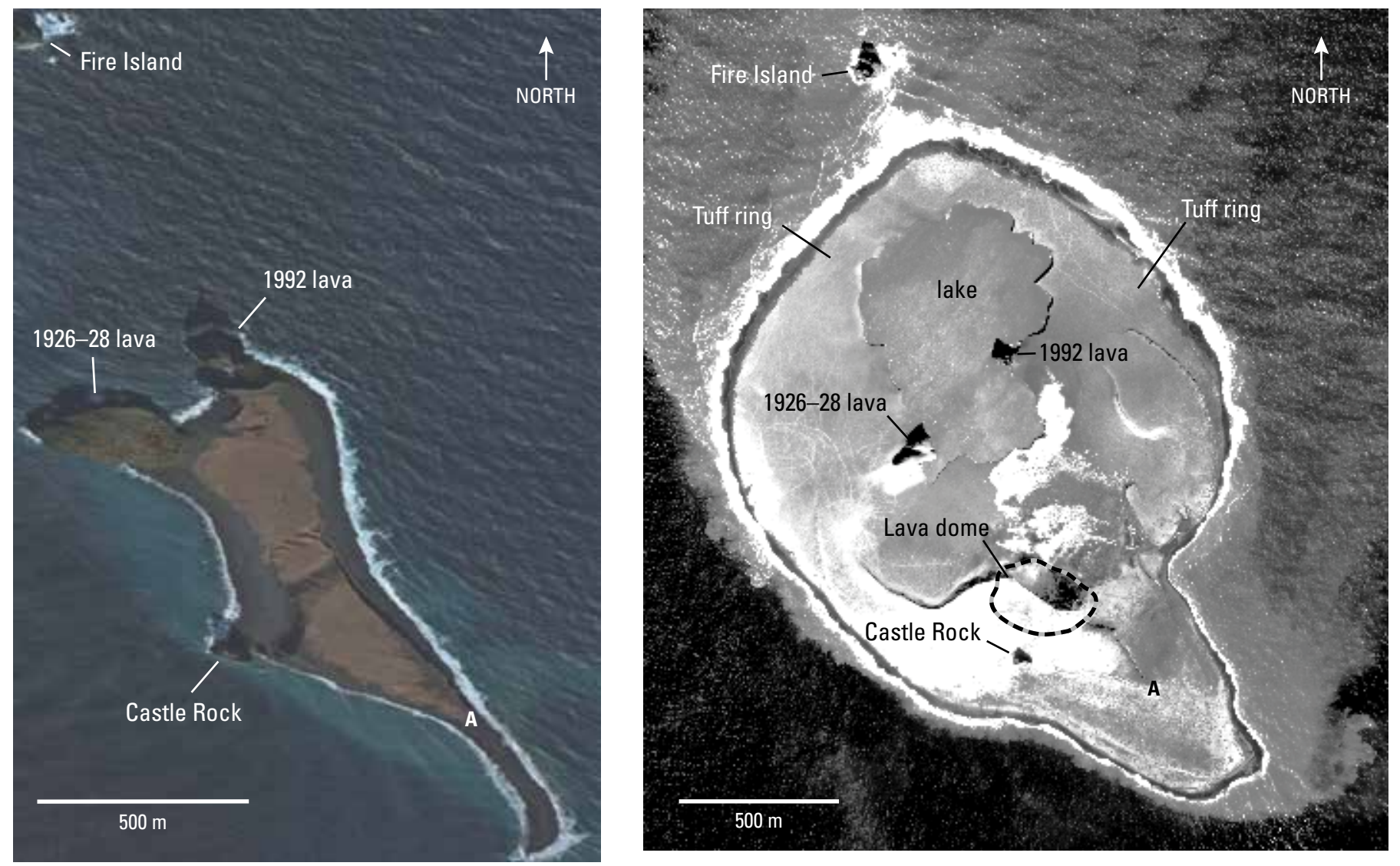

Figure 43. Satellite images of Bogoslof Island. Image on left from March 19, 2015; image on right from August 13, 2017. The feature labeled $A$ in both images is the same. The plan-view area of the island in the 2015 image is 0.28 square kilometers $\left(\mathrm{km}^{2}\right)$ and for the August 13, 2017, image the island area is $1.6 \mathrm{~km}^{2}$. Image data acquired with the DigitalGlobe NextView License. 


\section{Volcanic Clouds and Ash Fallout}

Historical eruptions of Bogoslof volcano appear similar in that most of them originated from eruptive vents that were at or below sea level. As a result, explosively generated eruption columns entrained unknown quantities of water that was heated and entirely or partly turned to steam. As the eruption cloud rose and cooled, liquid water in the plume formed ice particles. Satellite data and eyewitness observations of volcanic clouds associated with the 2016-17 eruption show that several volcanic clouds were characterized by a bright appearing top and a darker, possibly more ash rich base (fig. 44). The ice- and water-vapor-rich composition of the cloud likely inhibits ash fallout and as a result, significant ash fall has not been a reported characteristic of the 2016-17 eruption or any of the historical Bogoslof eruptions.

Ashfall was reported on Umnak Island during the 1796 eruption (von Kotzebue, 1821). Ash fallout on or near Unalaska Island (primarily the Dutch Harbor area) was reported in October 1882 (trace amounts), on September 1, 1907 (5-6 mm), on January 30-31, 2017 (trace amounts), and on March 8, 2017 (trace amounts in Dutch Harbor; minor ash fall on a boat about $50 \mathrm{~km}$ southeast of Bogoslof near Unalaska Island).

Drifting volcanic clouds generated by Bogoslof eruptions pose hazards to aircraft in the vicinity of the volcano. During the 2016-17 eruption, discrete ash-bearing volcanic clouds were identified in satellite imagery for distances of several hundred kilometers downwind of the volcano before dissipating and no longer being identifiable in satellite data.

Ash fall on towns and villages downwind of Bogoslof Island, such as Dutch Harbor/Unalaska and Nikolski, could disrupt air travel, impair drinking water supplies, and cause respiratory problems for sensitive individuals. Thicker accumulations of ash can create problems for machinery and electronic equipment. Additional information about potential hazards associated with ash fall can be found at https://volcanoes.usgs.gov/volcanic_ash/.

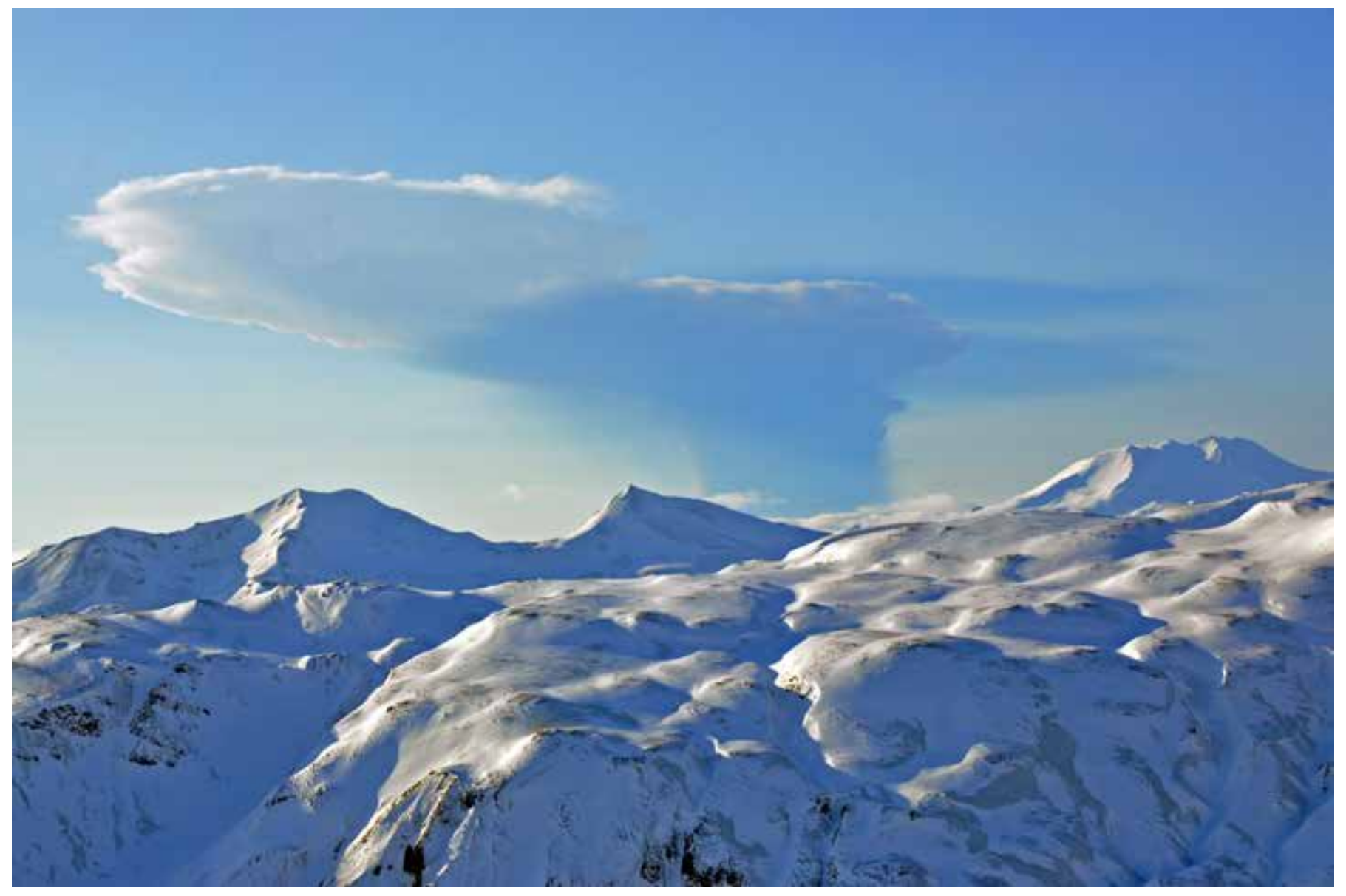

Figure 44. Photograph of volcanic eruption cloud at Bogoslof volcano, taken February 19, 2017. View is toward the northwest from Unalaska Island. This volcanic cloud is typical of the volcanic clouds generated during the 2016-17 eruption of Bogoslof volcano. Note the white ice- and water-vapor-rich portion of the cloud in the upper left and the darker, possibly more ash rich part of the cloud in the center of the photograph. Nearly all of the eruptive activity in 2016-17 was from a submarine vent and involved the evacuation of shallow seawater above the vent. Thus, the initial volcanic cloud of an eruptive sequence was commonly water rich, and subsequent emissions commonly appeared darker and slightly more ash rich, suggesting that the vent had dried out somewhat. The height of this particular cloud is not known, but is in the range of 9-12 kilometers $(30,000-40,000$ feet) above sea level. Photograph by Janet Schaefer, Alaska Division of Geological and Geophysical Surveys and Alaska Volcano Observatory. 


\section{Pyroclastic Base Surge}

Explosive, shallow submarine eruptions commonly generate vertically rising, cylindrical eruption columns with a ring-like, doughnut-shaped, horizontally moving basal cloud known as a base surge (Moore, 1967). Similar appearing clouds have been observed during shallow thermonuclear explosions and the term base surge was first applied to describe the radially moving basal clouds associated with these explosions (Glasstone, 1950; Glasstone and Dolan, 1977). Studies of the base surge associated with the Bikini Atoll submarine nuclear test indicated that the base surge developed near the crest of a large solitary wave adjacent to the seawater explosion crater as a result of expanding gases radiating from the explosion site (Young, 1965). Waterjets moving outward from the top of the solitary wave rapidly collapsed, forming spray that transformed to base surge. The main base surge developed before wholesale subsidence of the explosion column occurred, suggesting that the primary base surge was not associated with column collapse (Young, 1965). A secondary, but smaller, base surge developed subsequently and was apparently initiated by subsidence of the explosion column (Young, 1965). Phreatomagmatic eruptions at shallow submarine vents are undoubtedly more complex than single thermonuclear explosions and observations of phreatomagmatic submarine eruptions bear this out (Waters and Fisher, 1971). A plausible eruptive sequence for base surge development based on observations of the Capelinhos (Azores) and Taal (Philippines) eruptions (Moore, 1967; Waters and Fisher, 1971) involves the eruption of an unsteady debris-laden column with a basal, steam-rich, radially propagating collar, which is eventually overtaken by, and mixes with, eruption fall-back debris. The outward propagation of the steamcharged surge leads to the formation of a tuff ring.

Figure 37 shows a base surge in progress during the September 19, 1910, eruption of Bogoslof that looks remarkably similar to the base surges associated with eruptions of Taal Volcano and Capelinhos Volcano (Moore, 1967, fig. 8). A WorldView-3 satellite image of the May 28, 2017, eruption in progress is shown in figure 45 . The May 28 image shows new deposits of medium-grey (base surge?) material draping the tuff ring and extending into the sea on the southwest and east sides of Bogoslof Island, clear evidence that deposits were emplaced by pyroclastic flows (likely base surges) over the existing tuff ring during the May 28 eruption. Also apparent in the image are white, linear, ground-hugging clouds that extend radially from the turbulent, upward rising eruption column. The clouds have geometric characteristics that are similar to pyroclastic surges and may represent developing base surges associated with hydrovolcanic activity at Bogoslof on May 28. Similar appearing clouds have been observed during a number of "wet" eruptions at volcanoes with shallow submarine or subglacial vents (Moore, 1967; Waters and Fisher, 1971; Németh and others, 2006). It is possible that the linear clouds are related to the updraft and entrainment of ambient air surrounding the eruption column. It is unclear if linear clouds could form as cool air surrounding the eruption column is drawn over warm pyroclastic deposits on the tuff ring at Bogoslof. Although observations of base surge at Bogoslof are limited to these few images, it is clear from the images, the setting of the volcano, and some of the features and deposits formed during the 2016-17 eruption that this phenomenon can occur during Bogoslof eruptions.

Satellite images of Bogoslof Island obtained during the 2016-17 eruption show the progressive development of a tuff ring on the north, east, and southeast sectors of the island (Waythomas and others, 2017). Tuff rings are most commonly associated with strong phreatic and phreatomagmatic eruptions that generate highly inflated surge clouds (Wholetz and Sheridan, 1983; Sohn, 1996). Distinctive surface dunes with wavelengths of 1-5 m are arranged concentrically about presumed Bogoslof vents and are present in many of the satellite images from the 2016-17 eruption (Waythomas and others, 2017). These bedforms are characteristic features of pyroclastic surges formed during phreatic and phreatomagmatic eruptions (Moore, 1967; Waters and Fisher, 1971).

Studies of base surges generated by eruptions at Taal Volcano and Capelinhos Volcano indicate that soon after eruption onset, solid particles from the eruption column combine with the radially flowing steam-rich base surge to form wet, particle-laden density currents moving at hurricane speeds ( $>33$ meters per second $[\mathrm{m} / \mathrm{s}]$; Moore, 1967; Waters and Fisher, 1971). Although studies of base surges associated with thermonuclear explosions have concluded that eruption column collapse may play a secondary role in feeding the base surge (Young, 1965; Glasstone and Dolan, 1977), observations of phreatomagmatic eruptions in shallow marine environments indicate that fall-back of debris in the collapsing eruption column may be a significant mechanism for contributing mass and energy to the propagating base surge (Mastin and Witter, 2000).

Experimental explosion tests in gravel substrates have shown that optimum conditions for large, far-travelling base surges are large, discrete explosions at shallow explosion depths (Rohrer, 1965; Mastin and Witter, 2000). For example, a 1-kiloton terrestrial explosion at $10-15 \mathrm{~m}$ depth results in a base surge with a maximum run-out distance of $\sim 2.4 \mathrm{~km}$ (Rohrer, 1965). Base surges associated with the 1965 Taal eruption reached $6 \mathrm{~km}$ beyond the vent, which is the maximum known run-out distance of a modern base surge (Moore and others, 1966; Mastin and Witter, 2000). The run-out distance of a base surge is primarily a function of the size (or yield) of the submarine volcanic explosion and is roughly proportional to the 0.3 power of the yield for an explosion occurring at the optimal depth (Rohrer, 1965). The base surge that developed during the Baker submarine nuclear test attained a maximum speed of about $27 \mathrm{~m} / \mathrm{s}$ and after about 4 minutes traveled $\sim 2.8 \mathrm{~km}(11.6 \mathrm{~m} / \mathrm{s}$; Glasstone and Dolan, 1977). At this latter rate, it would take a comparably sized base surge about 9 minutes to travel $6 \mathrm{~km}$.

The kinetic energy per unit volume of a fluid in motion is known as the dynamic pressure (and can be expressed as 
Figure 45. Satellite image of steam-rich eruption column and developing base surge at Bogoslof volcano, May 28, 2017. Image data acquired with the DigitalGlobe NextView License.

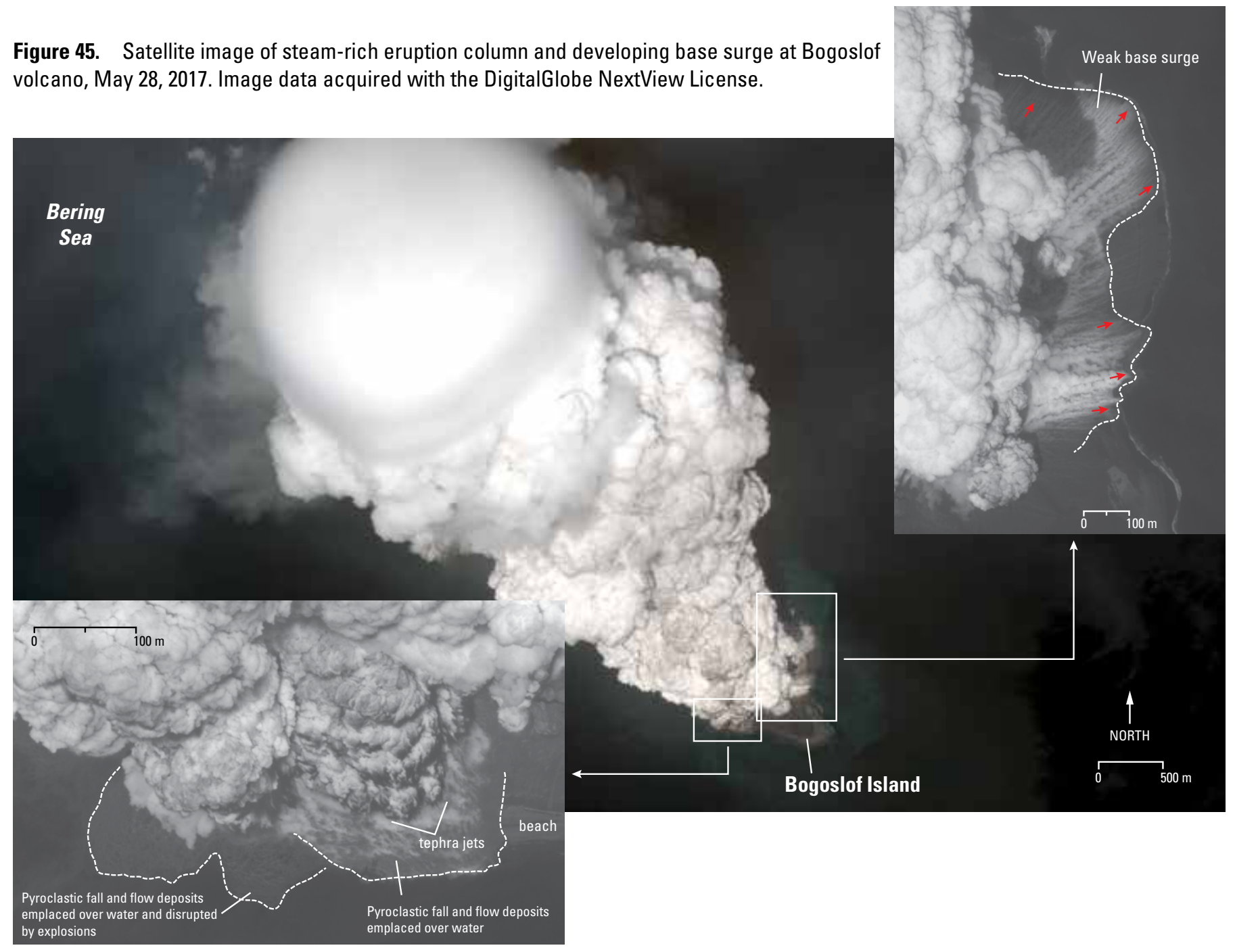

$$
p_{d y n}=\frac{1}{2} \rho v^{2}
$$

where $\rho$ is the fluid density and $v$ is the velocity of the fluid. A base surge can be considered a dilute pyroclastic density current as it consists mostly of water vapor and fine sediment (Waters and Fisher, 1971). Pyroclastic density currents have dynamic pressures of $1-10^{4}$ kiloPascals $(\mathrm{kPa}$; Valentine, 1998) and base surges likely have values toward the lower end of this range. For a base surge with a run-out distance in the range of 4-6 km (similar to the base surges generated by the 1965 Taal eruption) values for $P_{d y n}$ are $>35 \mathrm{kPa}$ as far as about $2.5 \mathrm{~km}$ from the eruption site (Brand and others, 2014). Although the specific effects of base surges this large on boats and ships is not known, studies of the effects of pyroclastic density currents on buildings and infrastructure indicate that total devastation results when $P_{d y n}>25 \mathrm{kPa}$ (Baxter and others, 2005). A base surge reaching $6 \mathrm{~km}$ beyond the vent would have an associated $P_{d y n}$ of roughly $5 \mathrm{kPa}$ (Brand and others, 2014), which is still considerable and could be sufficient to shatter window glass.

\section{Mud Rain}

The combined effects of seawater entrained by base surges, the evolving eruption column, and ambient moisture in the surrounding atmosphere can promote the development of wet ash fall in proximal areas around the volcano. The scavenging of ash by falling water drops or moisture-driven accretion may result in the development of mud rain (McKee and others, 1985; Gilbert and Lane, 1994). Wet compacted ash has a density of 1,000-2,000 kilograms per cubic meter $\left(\mathrm{kg} / \mathrm{m}^{3}\right)$ whereas dry uncompacted ash has a density of $500-1,300 \mathrm{~kg} / \mathrm{m}^{3}$ (Johnston, 1997). Thus, depending on the water content of the ash, a wet ash fall would pose a greater hazard to boats than a dry ash fall.

The extent of mud rain is difficult to predict. During very large shallow submarine eruptions with associated pyroclastic flows and surges that travelled over water, mud rain was reported as far as $80 \mathrm{~km}$ from the volcano, but was closely associated with the run-out of co-ignimbrite ash plumes 
(Carey and others, 1996). This suggests that the extent of significant mud rain may be roughly comparable to the extent of co-ignimbrite ash fallout. At Bogoslof, the mud rain zone may be roughly equivalent to the extent of pyroclastic base surges, or roughly $6-10 \mathrm{~km}$.

\section{Ballistic Ejecta}

Examination of high resolution satellite images of Bogoslof Island obtained throughout the 2016-17 eruption and observations made during other historical eruptions (table 1), have revealed that ejection of rock debris during explosive eruptive activity is a common process. Although the specific mechanism for producing the explosions required to fragment and eject rock debris from the vent(s) at Bogoslof is not known conclusively, magma-water interaction, and vulcanian and strombolian explosions, or some combination thereof, are the most likely processes. A vulcanian explosion brought about by the mechanical failure of a gas-impermeable plug of lava in the upper part of the magma column is a well-known mechanism for generating ballistic ejecta (Clarke and others, 2015). Such explosions are capable of launching particles as large as $50 \mathrm{~cm}$ in diameter $3-6 \mathrm{~km}$ from the vent and can have initial velocities of 40-400 m/s (Blong, 1996; Izgett and others, 2017). Ballistic projectiles generated during explosive eruptions are implicated as the cause of numerous fatalities and as many as 76 deaths have occurred worldwide between 1993 and 2017 (Fitzgerald and others, 2017).

\section{Floating Volcanic Debris}

Low-density volcanic material, such as pumice or scoria, generated during submarine eruptions may form floating accumulations or rafts (Simkin and Fiske, 1983; Jutzeler and others, 2014). Such rafts can remain intact and drift in the ocean more than $20,000 \mathrm{~km}$ from their source over months to years before they become waterlogged and sink or become dispersed by wind and wave action (Bryan and others, 2012). For example, the 2012 submarine eruption of Havre volcano in the Kermadec arc in the southwest Pacific Ocean produced a $>400$ square kilometer $\left(\mathrm{km}^{2}\right)$ pumice raft in about 1 day that was visible in satellite imagery for about 4 months after emplacement (Jutzeler and others, 2014). Rafts of volcanic debris produced by eruptions of Bogoslof volcano have the potential to disrupt maritime activities in the southern Bering Sea region. The seas surrounding Bogoslof are a major shipping route for transoceanic vessels and thousands of ships transit this area annually. The southern Bering Sea area in the vicinity of Bogoslof Island is also an important fishery and the area is utilized year round by the Bering Sea fishing fleet.

Floating volcanic material at Bogoslof was described in a report by von Kotzebue (1821) where "floating stones" extending for 3 miles $(5 \mathrm{~km})$ around the island were observed. Zones of discolored water of unknown composition have been observed numerous times during the 2016-17 eruption.
Some of these sediment plumes are visible in satellite data and extend as far as $20 \mathrm{~km}$ beyond Bogoslof Island (fig. 46). The general circulation of the upper part of the water column $(<40 \mathrm{~m})$ in the Bogoslof region of the southern Bering Sea is a counter-clockwise gyre roughly situated over the Umnak Plateau-Bering Canyon area (fig. 1; Stabeno and Reed, 1994; Stabeno and others, 1999). This circulation pattern suggests that floating volcanic debris could become trapped within the gyre and remain in the southeastern Bering Sea area until the material becomes water saturated and sinks.

\section{Submarine Slope Failures and Sector Collapse}

The shape, volume, and known eruptive products of Bogoslof volcano suggest that it is a stratovolcano edifice, which likely contains lava flows interbedded with unconsolidated pyroclastic-flow and fall deposits, and various submarine mass-wasting deposits. Volcanoes configured like this are known to be potentially gravitationally unstable and susceptible to collapse (Siebert, 1984). Flank collapse results in the formation of a debris avalanche and such deposits can be identified in bathymetric data. Many oceanic island volcanoes in Alaska exhibit features and deposits on their submarine flanks that are indicative of large subaerial to submarine slope failures (Waythomas and others, 2006; Coombs and others, 2007; Montanaro and Beget, 2011).

The available bathymetric data for the region surrounding Bogoslof Island shows no obvious evidence for large submarine slope failures and the telltale hummocky topography associated with debris avalanche deposits is apparently absent (fig. 4). Based on the morphology of the submarine flanks of the volcano, it does not appear that a large flank collapse has occurred throughout the history of the volcano. Given the present state of knowledge about the geology of Bogoslof volcano, it would be difficult to develop a rigorous assessment of the potential for flank collapse because nothing is known about the structure or prehistoric eruptive history of the volcano. Because other oceanic island volcanoes in Alaska exhibit evidence for flank collapse, we cannot completely discount the possibility of edifice failure at Bogoslof volcano. However, the available information indicates that this phenomenon has not occurred at any time in the history of the volcano.

\section{Explosively Generated Water Waves}

Submarine volcanic explosions at Bogoslof volcano involve thermomechanical interactions with the surrounding ocean. Shallow water $(<100 \mathrm{~m})$ volcanic explosions and sustained eruptive activity at Bogoslof are expected to disturb the water surface and thus could potentially generate associated water waves. Impulsively generated water waves at volcanoes are known as volcanic tsunamis (Latter, 1981) and depending on the magnitude of the source mechanism, could constitute a plausible hazard to coastal infrastructure in the Aleutian Islands southwest-southeast of the island. 


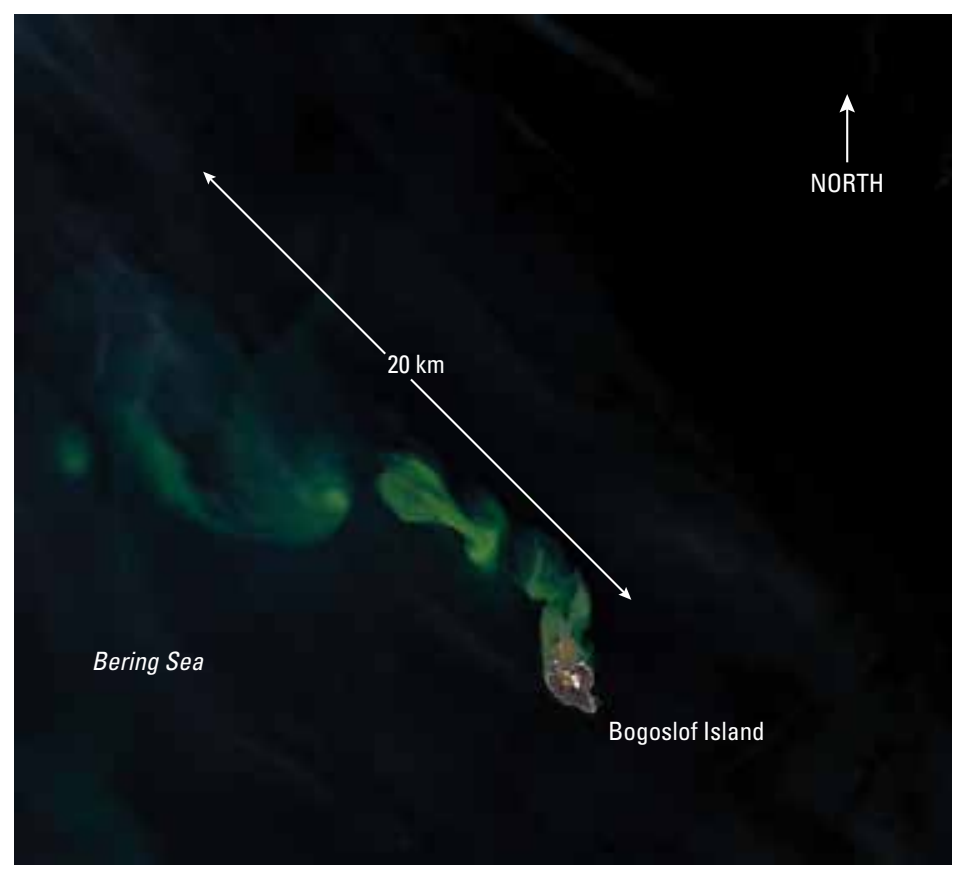

Figure 46. Landsat 8 Operational Land Imager natural-color image of Bogoslof, June 5, 2017. The green area is a near surface sediment plume of unknown composition that extends about 20 kilometers beyond Bogoslof Island to the northwest.

The explosive eruption that destroyed Metcalf Cone in 1907 may have initiated a small tsunami and the high-water marks of "flood waves" were described by Jaggar (1908b). A large, eruption-related dome of water was observed at Bogoslof on July 7, 1908 (Prosser, 1911). An apparently similar dome of water was observed during a 1952 submarine eruption of Myojin Reef volcano (Japan) that collapsed and formed a nearfield tsunami with a wave amplitude of $2 \mathrm{~m}$ and a wavelength of $50 \mathrm{~m}$ (Miyoshi, 1955). Other submarine-explosion-generated tsunamis occurred throughout the 1952-53 Myojin eruption and at least one of them resulted in tsunami waves with amplitudes of $1 \mathrm{~m}$ at distances of up to $130 \mathrm{~km}$ from the eruption site (Mirchina and Pelinovsky, 1988).

The explosive power of phreatomagmatic eruptions in shallow marine environments is difficult to determine; one approach is to calculate the energy source based on the resulting tsunami parameters (Le Mehaute, 1971; Mirchina and Pelinovsky, 1988). This approach was used for the largest events of the 1952-53 Myojin eruption, and the eruption energy was estimated in the range of $10^{15}-10^{16}$ joules (Mirchina and Pelinovsky, 1988), which is comparable to the yield of some of the most powerful nuclear bombs. The explosivity and attendant hazards of shallow submarine eruptions were tragically illustrated during a September 1952 event at Myojin Reef volcano. A hydrographic survey ship with 31 people on board approached the volcano to investigate the ongoing eruption and was destroyed and all aboard killed by an explosive burst from the volcano (Minakami, 1956). This example highlights the need to maintain a strict hazard zonation around Bogoslof Island while the volcano is restless and could potentially erupt.

\section{Expulsion of Hot Water}

There are numerous reports of warm to hot water in lagoons, shallow lakes, and local seawater associated with shallow magma and subaerial lava domes at Bogoslof (table 1). Observations made on January 10, 2017, show convective upwelling of water within a lagoon at Bogoslof likely driven by magmatic heat beneath the lagoon (fig. 47). Although not directly observed during the 2016-17 eruption, we suspect that there have been numerous episodes of low-level, geyser-like jets of water, mud, and ash associated with minor eruptive events. Such phenomena have been observed at Karymskoye Lake (Belousov and Belousova, 2001) and from within the crater lake at Ruapehu volcano (Kilgour, and others, 2010). Intermittent, unheralded minor emissions of steam and hot water could pose a significant hazard to animals and anyone on Bogoslof Island while the volcano remains in a restless condition.

\section{Hazard Zonation}

A preliminary hazard map for Bogoslof volcano is shown in figure 48. This map depicts all of the hazards described previously except expulsion of hot water, which would be restricted to within very close proximity to Bogoslof Island. The maximum reported run-out distance for base surge is $6 \mathrm{~km}$ (Moore, 1967; Mastin and Witter, 2000), and the outer base surge hazard boundary is located at a distance of $10 \mathrm{~km}$ from Bogoslof Island. It is unlikely that a Bogoslof eruption similar to the historically observed eruptions would produce base 


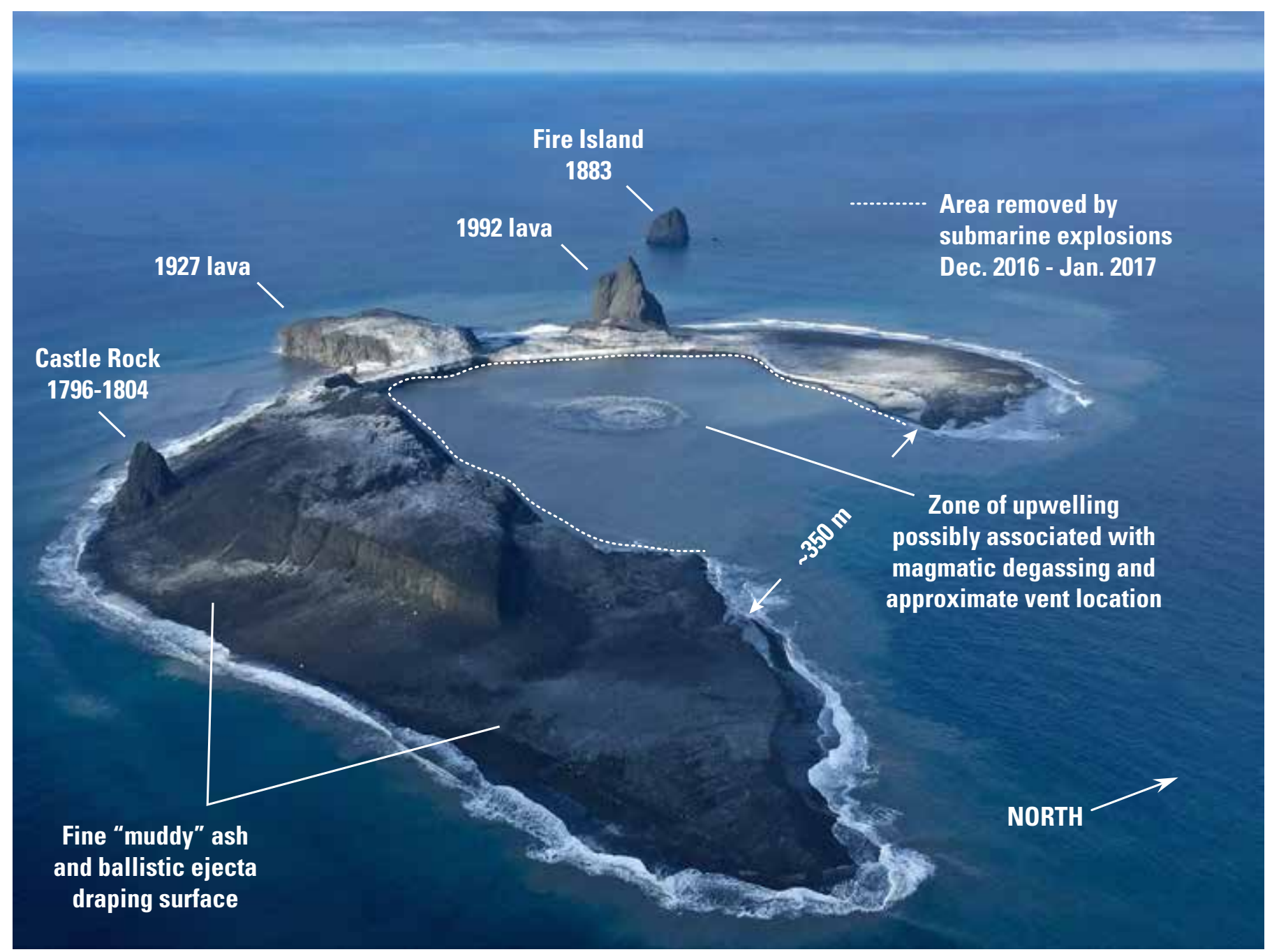

Figure 47. Photograph of Bogoslof Island, January 10, 2017. Note prominent zone of upwelling in the center part of the lagoon likely associated with thermally driven convective overturning of the water. Photograph by D. Leary. M, meters.

surges that would exceed these boundaries. We have yet to evaluate the energetics of base surges at Bogsolof based on studies of the tuff ring deposits. The extent of floating debris in concentrations high enough to pose a hazard to ships is also uncertain. The extent of the hazard zone is based on the maximum observed extent of discolored water observed in satellite images during the $2016-17$ eruption. The hazard zone for ballistic ejecta extends to $4 \mathrm{~km}$ beyond Bogoslof Island and is based on data from the literature described above.

It should be noted that the hazard zones depicted in figure 48 do not have absolute boundaries and are based on the historical record of eruptive activity as described in this report. It is possible that conditions at the volcano different from those that have been observed historically could develop, and larger, more powerful eruptions may occur. 

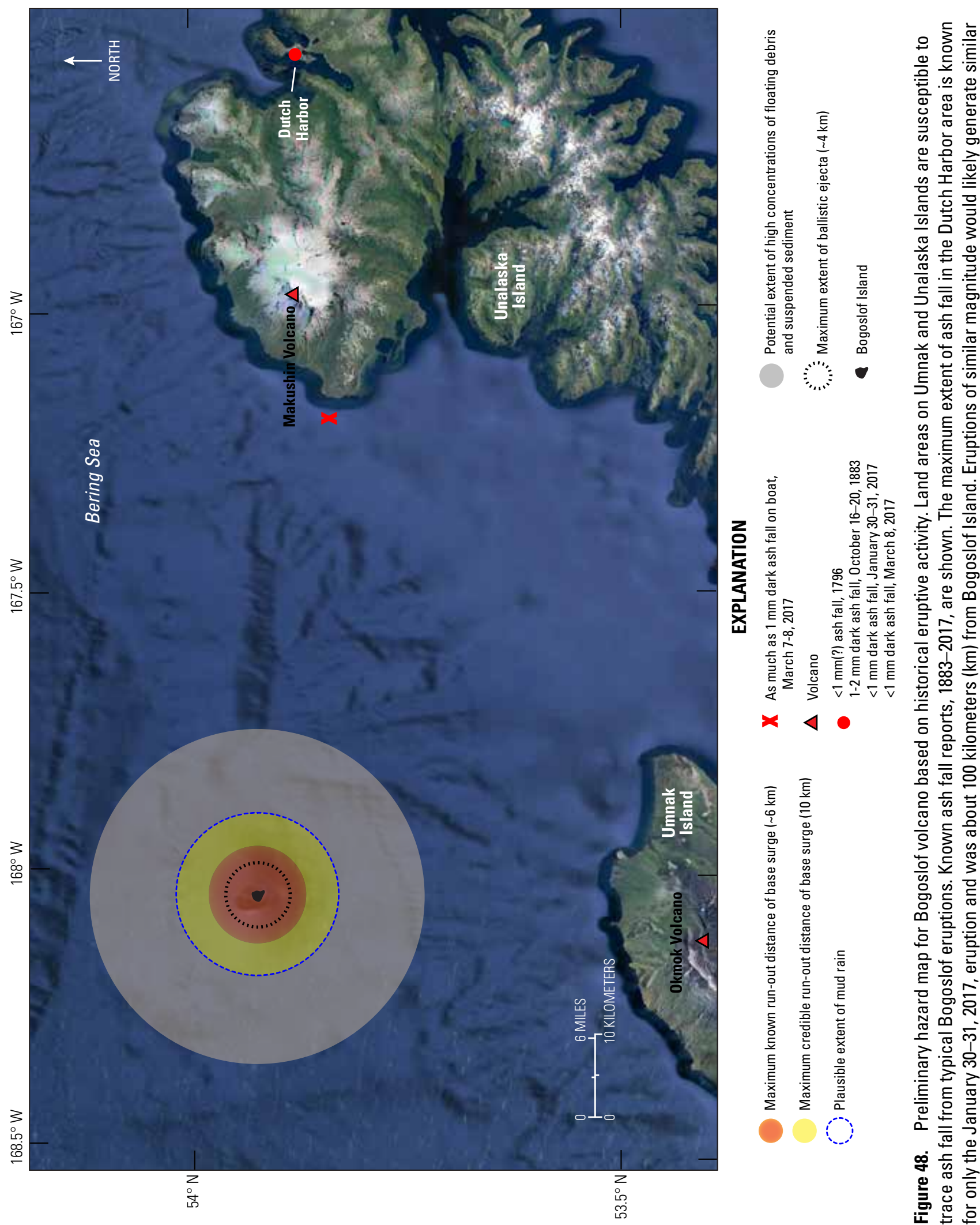

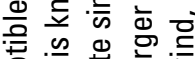

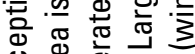

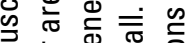
के

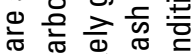
里现

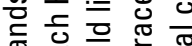
$\frac{\pi}{\infty}$

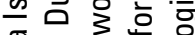
ॠ 즌 劳 元 든 $\frac{5}{\pi}$ 줃 㫕施焉

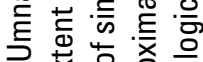
ᄃ

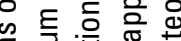
ब 늠
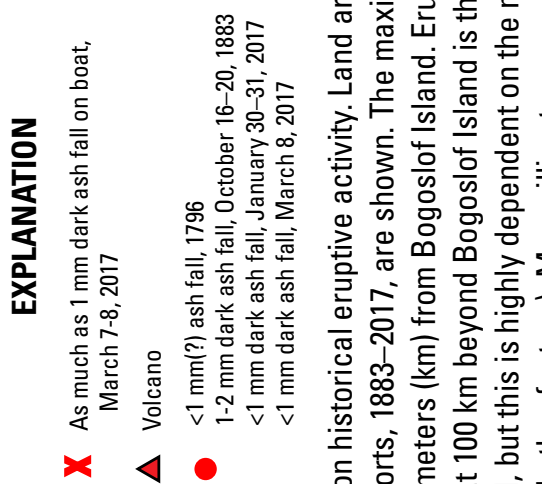

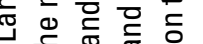
它古 $\frac{\pi}{\omega}$

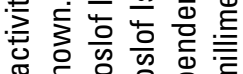

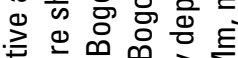
음 능

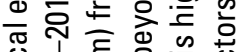
은

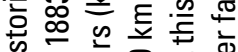

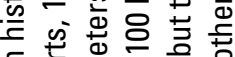

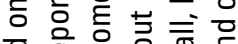

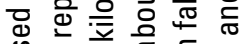
沓

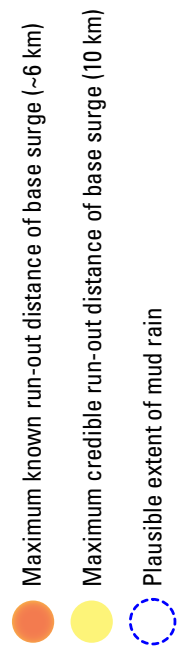

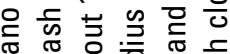
豞

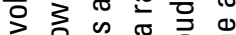
눙 원

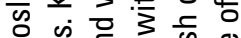

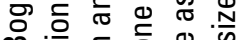

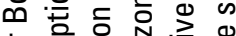

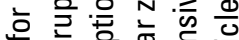
원을 을

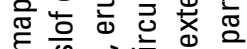

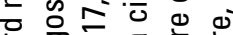

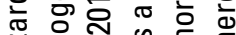
뜬을 젛ㅍㅎ

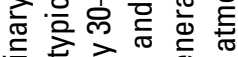
든 至

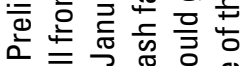
人

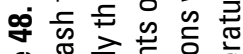

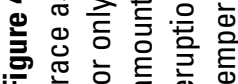




\section{References Cited}

Baker, M., 1906, Geographic dictionary of Alaska (2d ed.): U.S. Geological Survey Bulletin 299, 690 p. [Also available at https://pubs.er.usgs.gov/publication/b299.]

Baxter, P.J., Boyle, R., Cole, P., Neri, A., Spence, R.J.S., and Zuccaro, G., 2005, The impacts of pyroclastic surges on buildings at the eruption of the Soufrière Hills volcano, Montserrat: Bulletin of Volcanology, v. 67, no. 4, p. 292-313. [Also available at https://doi.org/10.1007/s00445004-0365-7.]

Becker, G.F., 1898, Reconnaissance of the gold fields of southern Alaska, with some notes on general geology, in Walcott, C.D., ed., Eighteenth annual report-Part III-Economic geology: U.S. Geological Survey Annual Report 0018, p. 1-86. [Also available at https://pubs.er.usgs.gov/publication/ar18_3.]

Belousov, A., and Belousova, M., 2001, Eruptive process, effects and deposits of the 1996 and the ancient basaltic phreatomagmatic eruptions in Karymskoye lake, Kamchatka, Russia, in White, J.D.L., and Riggs, N.R., Volcanogenic sedimentation in lacustrine settings: Oxford, Blackwell Science, International Association of Sedimentologists Special Publication 30, p. 35-60.

Ben-Avraham, Z., and Cooper, A.K., 1981, Early evolution of the Bering Sea by collision of oceanic rises and North Pacific subduction zones: Geological Society of America Bulletin, v. 92, no. 7, p. 485-495. [Also available at https:// doi.org/10.1130/0016-7606(1981)92<485:EEOTBS $>2.0$ .CO;2.]

Bergsland, K., 1994, Aleut dictionary (Unangam Tunudgusii) - An unabridged lexicon of the Aleutian, Pribilof, and Commander Islands Aleut Language: Fairbanks, Alaska, University of Alaska-Fairbanks, Alaska Native Language Center, $854 \mathrm{p}$.

Blong, R.J., 1996, Volcanic hazards risk assessment, in Scarpa, R., and Tilling, R.I., eds., Monitoring and mitigation of volcanic hazards: Berlin, Springer, p. 675-698. [Also available at https://doi.org/10.1007/978-3-642-80087-0_20.]

Brand, B.D., Gravley, D.M., Clarke, A.B., Lindsay, J.M., Bloomberg, S.H., Agustin-Flores, J., and Németh, K., 2014, A combined field and numerical approach to understanding dilute pyroclastic density current dynamics and hazard potential - Auckland Volcanic Field, New Zealand: Journal of Volcanology and Geothermal Research, v. 276, p. 215-232. [Also available at http://doi.org/10.1016/j. jvolgeores.2014.01.008.]
Bryan, S.E., Cook, A.G., Evans, J.P., Hebden, K., Hurrey, L., Colls, P., Jell, J.S., Weatherley, D., and Firn, J., 2012, Rapid, long-distance dispersal by pumice rafting: PLoS One, v. 7 , no. 7 , p. e40583, accessed November 2017, at https://doi. org/10.1371/journal.pone.0040583.

Byers, F.M., Jr., 1959, Geology of Umnak and Bogoslof Islands, Aleutian Islands, Alaska: U.S. Geological Survey Bulletin 1028-L, p. 267-369. [Also available at https://pubs. er.usgs.gov/publication/b1028L.]

Byers, F.M., Jr., 1961, Petrology of three volcanic suites, Umnak and Bogoslof Islands, Aleutian Islands, Alaska: Geological Society of America Bulletin, v. 72, no. 1, p. 93-128. [Also available at https://doi.org/10.1130/00167606(1961)72[93:POTVSU]2.0.CO;2.]

Calder, E.S., Lavallée, Y., Kendrick, J.E., and Bernstein, M., 2015, Lava dome eruptions, in Sigurdsson, H., Houghton, B., McNutt, S., Rymer, H., and Stix, J., eds., The encyclopedia of volcanoes (2d ed.): San Diego, Calif., Academic Press, p. 343-362. [Also available at https://doi. org/10.1016/B978-0-12-385938-9.00018-3.]

Carey, S., Sigurdsson, H., Mandeville, C., and Bronto, S., 1996, Pyroclastic flows and surges over water-An example from the 1883 Krakatau eruption: Bulletin of Volcanology, v. 57, no. 7, p. 493-511. [Also available at https://doi. org/10.1007/BF00304435.]

Clarke, A.B., Ongaro, T., and Belousov, A., 2015, Vulcanian eruptions, in Sigurdsson, H., Houghton, B., McNutt, S., Rymer, H., and Stix, J., eds., The encyclopedia of volcanoes (2d ed.): San Diego, Calif., Academic Press, p. 505-518. [Also available at https://doi.org/10.1016/B978-0-12385938-9.00028-6.]

Cook, J., 1785, A voyage to the Pacific Ocean, volume 2: London, H. Hughes, 511 p.

Coombs, M.L., White, S.M., and Scholl, D.W., 2007, Massive edifice failure at Aleutian arc volcanoes: Earth and Planetary Science Letters, v. 256, no. 3-4, p. 403-418. [Also available at https://doi.org/10.1016/j.epsl.2007.01.030.]

Dall, W.H., 1884, A new volcano island in Alaska: Science, v. 3, no. 51, p. 89-93.

Davidson, G., 1884, The new Bogoslof volcano in the Bering Sea: Science, v. 3, no. 57 , p. 282-286. [Also available at https://doi.org/10.1126/science.ns-3.57.282.]

Diller, J.S., 1884, Volcanic sand which fell at Unalashka, Alaska, Oct. 20, 1883, and some considerations concerning its composition: Science, v. 3, no. 69, p. 651-654. 
Dunn, R., 1908, On the chase for volcanoes, I-Through the fires of the world's youngest island: Outing Magazine, v. 51, p. $442-454$.

Eakle, A.S., 1908, Recent volcanic eruptions in Bering Sea: Mining and Scientific Press, v. 96, p. 353.

Engebretson, D.C., Cox, A., and Gordon, R.G., 1985, Relative motions between oceanic and continental plates in the Pacific basin: Geological Society of America Special Paper 206, 60 p.

Fitzgerald, R.H., Kennedy, B.M., Wilson, T.M., Leonard, G.S., Tsunematsu, K., and Keys, H., 2017, The communication and risk management of volcanic ballistic hazards, in Nemeth, K., ed., Advances in volcanology: Berlin, Springer, p. 1-27. [Also available at http://doi. org/10.1007/11157_2016_35.]

Fournelle, J.H., Marsh, B.D., and Myers, J.D., 1994, Age, character, and significance of Aleutian arc volcanism, in Plafker, G., and Berg, H.C., eds., The Geology of Alaska: Geological Society of America, The Geology of North America Series, v. G-1, p. 723-758.

Gilbert, J.S., and Lane, S.J., 1994, The origin of accretionary lapilli: Bulletin of Volcanology, v. 56, no. 5, p. 398-411. [Also available at https://doi.org/10.1007/BF00326465.]

Glasstone, S., ed., 1950, The effects of atomic weapons: Washington, D.C., Government Printing Office, prepared for U.S. Atomic Energy Commission under direction of Los Alamos Scientific Laboratory, $456 \mathrm{p}$.

Glasstone, S., and Dolan, P.J., comps., 1977, Effects of nuclear weapons ( $3 \mathrm{~d}$ ed.): Department of Defense and Department of Energy, Washington, D.C., No. TID-28061, 653 p.

Global Volcanism Program, 1992, Report on Bogoslof (United States): Bulletin of the Global Volcanism Network, v. 17, no. 7. [Also available at https://doi.org/10.5479/si.GVP. BGVN199207-311300.]

Grewingk, C., 1850, Grewingk's geology of Alaska and the Northwest Coast of America, [Falk, W., ed., Jaensch, F., trans., 2003]: Fairbanks, Alaska, The University of Alaska Press, Rasmuson Library Historical Translation Series 11, $242 \mathrm{p}$.

Harbin, M.L., 1994, Observations of the 1992 lava dome, Bogoslof Island, eastern Aleutian Arc, Alaska: Eos, v. 75, no. 44 , p. 737.

Harriman, E.H., and Merriam, C.H., 1901, Alaska-History, geography, resources: Washington, D.C., Washington Academy of Sciences.
Healy, M.A., 1889, Report of the cruise of the Revenue Marine steamer Corwin in the Arctic Ocean, in the year 1884: Washington, D.C., Government Printing Office, 128 p.

Hildreth, W., Fierstein, J., and Calvert, A.T., 2007, Blue Mountain and The Gas Rocks - Rear-arc dome clusters on the Alaska Peninsula, in Haeussler, P.J., and Galloway, J.P., eds., Studies by the U.S. Geological Survey in Alaska, 2006: U.S. Geological Survey Professional Paper 1739-A, 27 p. [Also available at https://pubs.usgs.gov/pp/pp1739/a/.]

Hudson, R., and Mason, R., 2014, Lost villages of the eastern Aleutians-Biorka, Kashega, Makushin: National Park Service, Government Printing Office, 331 p.

Hunnicutt, E.W., 1943, Bogoslof the moving island: Alaska Life, v. 6, n. 4, p. 55-58.

Isgett, S.J., Houghton, B.F., Fagents, S.A., Biass, S., Burgisser, A., and Arbaret, L., 2017, Eruptive and shallow conduit dynamics during Vulcanian explosions - Insights from the episode IV block field of the 1912 eruption of Novarupta, Alaska: Bulletin of Volcanology, v. 79, no. 58. [Also available at https://link.springer.com/content/ pdf/10.1007\%2Fs00445-017-1138-4.pdf.]

Jacob, K.H., Nakamura, K., and Davies, J.N., 1977, Trenchvolcano gap along the Alaska-Aleutian Arc-Facts, and speculations on the role of terrigenous sediments for subduction, in Talwani, M., and Pitman, W.C., III., eds., Island arcs, deep sea trenches and back-arc basins: American Geophysical Union Maurice Ewing Series 0001, p. 243-258.

Jaggar, T.A., Jr., 1908a, Journal of the technology expedition to the Aleutian Islands, 1907: The Technology Review, v. 10, no. 1, p. 1-37.

Jaggar, T.A., Jr., 1908b, The evolution of Bogoslof Volcano: Bulletin of the American Geographical Society, v. 40, no. 7, p. 385-400. [Also available at https://doi. org/10.2307/198507.]

Jaggar, T.A., Jr., 1927, Aleutian volcanology: The Volcano Letter, no. 147, p. 1.

Jaggar, T.A., Jr., 1930, Recent activity at Bogoslof Volcano: The Volcano Letter, no. 275, p. 1-3.

Jaggar, T.A., Jr., 1932, Aleutian eruptions 1930-1932: The Volcano Letter, v. 375, p. 1-4.

Johnston, D.M., 1997, The impacts of recent falls of volcanic ash on public utilities in two communities in the United States of America: Institute of Geological and Nuclear Sciences report 97/5, $21 \mathrm{p}$. 
Jordan, D.S., and Clark, G.A., 1906, The Bogoslofs: Popular Science Monthly, v. 69, p. 481-489.

Jutzeler, M., Marsh, R., Carey, R.J., White, J.D.L., Talling, P.J., and Karlstrom, L., 2014, On the fate of pumice rafts formed during the 2012 Havre submarine eruption: Nature Communications, v. 5, art. 3660, 10 p. [Also available at https://doi.org/10.1038/ncomms4660.]

Kilgour, G., Manville, V., Della Pasqua, F., Graettinger, A., Hodgson, K.A., and Jolly, G.E., 2010, The 25 September 2007 eruption of Mount Ruapehu, New Zealand-Directed ballistics, surtseyan jets, and ice-slurry lahars: Journal of Volcanology and Geothermal Research, v. 191, no. 1-2, p. 1-14. [Also available at https://doi.org/10.1016/j.jvolgeores.2009.10.015.]

Krusenstern, I.F., 1926, Atlas of the Pacific Ocean (in Russian): St. Petersburg, Russia.

Larkin, F.J., 1998, Basic coastal navigation-An introduction to piloting for sail and power ( $2 \mathrm{~d}$ ed.): Dobbs Ferry, N.Y., Sheridan House, 196 p.

Latter, J.H., 1981, Tsunamis of volcanic origin-Summary of causes, with particular reference to Krakatoa, 1883: Bulletin of Volcanology, v. 44, no. 3, p. 467-490. [Also available at https://doi.org/10.1007/BF02600578.]

Le Mehaute, B., 1971, Theory of explosion-generated water waves, in Chow, V.T., ed., Advances in hydroscience, volume 7-1971: New York, Academic Press, p. 1-79.

Lütke, F., 1836, Voyage autour de monde exécuté par ordre de sa Majesté l'Empereur Nicolas 1er, sur la corvette Le Séniavine dans les années 1826, 1827, 1828 et 1829 [Boyé, J., trans.]: Parte nautique, C. Hintze, St. Petersburg.

Marsh, B.D., and Leitz, R.E., 1979, Geology of Amak Island, Aleutian Islands, Alaska: The Journal of Geology, v. 87 , no. 6 , p. 715-723. [Also available at https://doi. org $/ 10.1086 / 628461$.

Mastin, L.G., and Witter, J.B., 2000, The hazards of eruptions through lakes and seawater: Journal of Volcanology and Geothermal Research, v. 97, no. 1-4, p. 195-214. [Also available at https://doi.org/10.1016/S0377-0273(99)001742.]

McGimsey, R.G., Neal, C.A., and Doukas, M.P., 1995, Volcanic activity in Alaska; summary of events and response of the Alaska Volcano Observatory 1992: U.S. Geological Survey Open-File Report 95-83, 26 p. [Also available at https://pubs.er.usgs.gov/publication/ofr9583.]
McKee, C.O., Johnson, R.W., Lowenstein, P.L., Riley, S.J., Blong, R.J., de Saint Ours, P., and Talai, B., 1985, Rabaul caldera, Papua New Guinea-Volcanic hazards, surveillance, and eruption contingency planning: Journal of Volcanology and Geothermal Research, v. 23, no. 3-4, p. 195-237. [Also available at https://doi.org/10.1016/03770273(85)90035-6.]

Merriam, C.H., 1901, Bogoslof, our newest volcano, in Merriam, C.H., ed., Harriman Alaska expedition, volume 2: New York, Doubleday, Page and Co., p. 291-336.

Merriam, C.H., 1902, Bogoslof volcanoes: Smithsonian Institution Annual Report 1901, p. 367-375.

Minakami, T., 1956, Report on volcanic activities and volcanological studies in Japan for the period from 1951 to 1954: Bulletin of Volcanology, v. 18, no. 1, p. 39-76. [Also available at https://doi.org/10.1007/BF02596612.]

Mirchina, N.R., and Pelinovsky, E.N., 1988, Estimation of underwater eruption energy based on tsunami wave data: Natural Hazards, v. 1, no. 3, p. 277-283. [Also available at https://doi.org/10.1007/BF00137232.]

Miyoshi, H., 1955, Explosion waves accompanying the eruptions of Myojin Reef: Journal of the Oceanographical Society of Japan, v. 11, no. 4, p. 157-163. [Also available at https://doi.org/10.5928/kaiyou1942.11.157.]

Montanaro, C., and Beget, J., 2011, Volcano collapse along the Aleutian Ridge (western Aleutian Arc): Natural Hazards and Earth System Sciences, v. 11, no. 3, p. 715-730.

Moore, J.G., Nakamura, K., and Alcaraz, A., 1966, The 1965 eruption of Taal volcano: Science, v. 151, no. 3713, p. 955-960.

Moore, J.G., 1967, Base surge in recent volcanic eruptions: Bulletin of Volcanology, v. 30, no. 1, p. 337-363. [Also available at https://doi.org/10.1007/BF02597678.]

Morris, G.E., 1936, Bogoslof Island: U.S. Coast and Geodetic Survey, Field Engineers Bulletin, no. 10, p. 110-121.

Munger, F.M., 1909, A jack in the box-An account of the strange performances of the most wonderful island in the world: National Geographic Magazine, v. 20, no. 1-6, p. 194-199.

Németh, K., Cronin, S.J., Charley, D.T., Harrison, M.J., and Garae, E., 2006, Exploding lakes in Vanuatu-“Surtseyanstyle" eruptions witnessed on Ambae Island: Episodes, v. 29 , no. 2, p. 87-93. 
Powers, H.A., 1958, Alaska Peninsula-Aleutian Islands, in Williams, H., ed., Landscapes of Alaska-Their geological evolution: Los Angeles, Calif., University of California Press, p. 61-75.

Powers, S., 1916, Recent changes in Bogoslof Volcano: Geographical Review, v. 2, no. 3, p. 218-221. [Also available at https://doi.org/10.2307/207507.]

Prosser, W.T., 1911, Nature turned sorceress: The Technical World Magazine, v. XV, no. 1, p. 64-68.

Roberts, H., 1794, Chart of the N.W. coast of America and the N.E. coast of Asia, explored in the years 1778 and 1779: London, Published by Wm. Faden, Geographer to the King. [Also available at https://open.library.ubc.ca/collections/ specialp/items/1.0065890.]

Rohrer, R. 1965, Base surges and cloud formation-Project pre-Schooner: California University Livermore, Lawrence Radiation Lab, PNE-503F, 10 p.

Sarychev, G.A., 1826, Atlas Severnoy chasti Vostochnago Okeana: so stavlen v chertezhnoy Gosudarstvennago Admiraltezhkago Departamenta, s Novgyshikh opisey i kart, St. Petersburg.

Scholl, D.W., Buffington, E.C., and Hopkins, D.M., 1968, Geologic history of the continental margin of North America in the Bering Sea: Marine Geology, v. 6, no. 4, p. 297-330. [Also available at https://doi.org/10.1016/00253227(68)90021-2.]

Scholl, D.W., Buffington, E.C., Hopkins, D.M., and Alpha, T.R., 1970, The structure and origin of the large submarine canyons of the Bering Sea: Marine Geology, v. 8, no. 3-4, p. 187-210. [Also available at https://doi.org/10.1016/00253227(70)90043-5.]

Scholl, D.W., Buffington, E.C., and Marlow, M.S., 1975, Plate tectonics and the structural evolution of the Aleutian-Bering Sea region, in Forbes, R.B., ed., Contributions to the geology of the Bering Sea Basin and adjacent regions: Geological Society of America Special Paper 151, p. 1-31. [Also available at https://doi.org/10.1130/SPE151-p1.]

Shavanov, I., 1772, Karta merkatorskaia, publisher unknown: University of Alaska-Fairbanks Library Rare Maps Collection, Alaska and Polar Regions collection. [Also available at http://vilda.alaska.edu/cdm/singleitem/collection/cdmg11/ $\mathrm{id} / 10450 / \mathrm{rec} / 1$.

Sherrod, D.R., Scott, W.E., and Stauffer, P.H., eds., 2008, A volcano rekindled-The renewed eruption of Mount St. Helens, 2004-2006: U.S. Geological Survey Professional Paper 1750, 856 p. [Also available at https://pubs.usgs.gov/ pp/1750/.]
Siebert, L., 1984, Large volcanic debris avalanches-Characteristics of source areas, deposits, and associated eruptions: Journal of Volcanology and Geothermal Research, v. 22, no. 3-4, p. 163-197. [Also available at https://doi. org/10.1016/0377-0273(84)90002-7.]

Simkin, T., and Fiske, R.S., 1983, Krakatau 1883 eruption and its effects: Washington, D.C., Smithsonian Institution Press, $464 \mathrm{p}$.

Smith, P.A., 1937, The submarine topography of Bogoslof: Geographical Review, v. 27, no. 4, p. 630-636. [Also available at https://doi.org/10.2307/209861.]

Sohn, Y.K., 1996, Hydrovolcanic processes forming basaltic tuff rings and cones on Cheju Island, Korea: Geological Society of America Bulletin, v. 108, no. 10, p. 1199-1211. [Also available at https://doi.org/10.1130/00167606(1996)108\%3C1199:HPFBTR\%3E2.3.CO;2.]

Stabeno, P.J., and Reed, R.K., 1994, Circulation in the Bering Sea basin observed by satellite-tracked drifters-1986-1993: Journal of Physical Oceanography, v. 24, no. 4, p. 848-854. [Also available at https://doi. org/10.1175/1520-0485(1994)024\%3C0848:CITBSB\%3E2 .0.CO;2.]

Stabeno, P.J., Schumacher, J.D., and Ohtani, K., 1999, The physical oceanography of the Bering Sea, in Loughlin, T.R., and Ohanti, K., eds., Dynamics of the Bering Sea: Fairbanks, Alaska, University of Alaska, p. 1-28.

Tebenkov, M.D., 1852, Atlas of the northwest coasts of America with hydrographic notes [Pierce, R.A., trans. and ed., 1981]: Kingston, Ontario, Limestone Press.

Tibaldi, A., and Bonali, F.L., 2017, Intra-arc and back-arc volcano-tectonics-Magma pathways at Holocene AlaskaAleutian volcanoes: Earth-Science Reviews, v. 167, p. 1-26. [Also available at http://doi.org/10.1016/j.earscirev.2017.02.004.]

Valentine, G.A., 1998, Damage to structures by pyroclastic flows and surges, inferred from nuclear weapons effects: Journal of Volcanology and Geothermal Research, v. 8, no. $1-4$, p.117-140.

Veniaminov, I., 1840, Notes on the islands of the Unalashka district [Pierce, R.A., ed., Black, L.T., and Geoghegan, R.H., trans., 1984]: Kingston, Ontario, Limestone Press, $511 \mathrm{p}$.

von Kotzebue, O., 1821, Voyage of discovery in the South Sea and Beering's Straits, volume 3: London, Longman, Hurst, Rees, Orme, and Brown, $456 \mathrm{p}$.

von Langsdorff, G.H., 1817, Voyages and travels in various parts of the world, during the years 1803, 1804, 1805, 1806, and 1807: Carlisle, Pa., George Phillips. 
Waters, A.C. and Fisher, R.V., 1971, Base surges and their deposits - Capelinhos and Taal volcanoes: Journal of Geophysical Research, v. 76, no. 23, p. 5596-5614.

Waythomas, C.F., Schneider, D., Angeli, K., Burton, W., Cameron, C., Cervelli, P., Coombs, M., Izbekov, P., Larsen, J., Mastin, L., McGimsey, R., Schaefer, J., Van Eaton, A., Wallace, K., and Wessels, R., 2017, 2016-17 Shallow submarine eruption of Bogoslof Volcano, Alaska-Preliminary observations and eruptive products at a back-arc volcano in the southern Bering Sea [abs.]: IAVCEI Scientific Assembly 2017, Abstracts, p. 1,206, accessed August 2017, at http:// iavcei2017.org/IAVCEI\%202017\%20Abstracts.pdf.

Waythomas, C.F., Watts, P., and Walder, J.S., 2006, Numerical simulation of tsunami generation by cold volcanic mass flows at Augustine Volcano, Alaska: Natural Hazards and Earth System Sciences, v. 6, no. 5, p. 671-685.
Wohletz, K.H., and Sheridan, M.F., 1983, Hydrovolcanic explosions; II, Evolution of basaltic tuff rings and tuff cones: American Journal of Science, v. 283, no. 5, p. 385-413.

Wood, C.A., and Kienle, J., eds., 1990, Volcanoes of North America: United States and Canada: Cambridge University Press, $354 \mathrm{p}$.

Wynne, J.J., Shahan, T.J., Pallen, C.B., Pace, E.A., and Herbermann, C.G., 1913, The Catholic encyclopedia-An international work of reference on the constitution, doctrine, discipline, and history of the Catholic church: Encyclopedia Press, 799 p.

Young, G.A., 1965, The physics of the base surge: New York, New York University, Ph.D. dissertation, 294 p. 
Menlo Park Publishing Service Center, California Manuscript approved June 22, 2018

Edited by Scott Darling and Katherine Jacques Layout by Vivian Nguyen 
